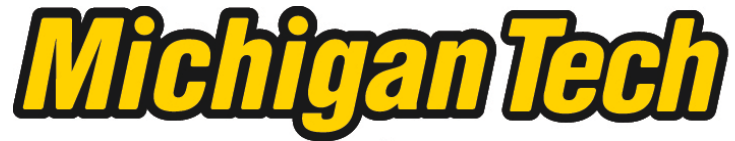 \\ Michigan Technological University Create the Future Digital Commons @ Michigan Tech
}

Dissertations, Master's Theses and Master's Reports - Open

Dissertations, Master's Theses and Master's

Reports

2006

Inquiry and understanding : educational research with middle level science students

Deborah A. Sage

Michigan Technological University

Follow this and additional works at: https://digitalcommons.mtu.edu/etds

Part of the Science and Mathematics Education Commons

Copyright 2006 Deborah A. Sage

\section{Recommended Citation}

Sage, Deborah A., "Inquiry and understanding : educational research with middle level science students ", Master's report, Michigan Technological University, 2006.

https://doi.org/10.37099/mtu.dc.etds/532

Follow this and additional works at: https://digitalcommons.mtu.edu/etds

8 Part of the Science and Mathematics Education Commons 


\title{
Inquiry and Understanding: Educational Research with Middle Level Science Students
}

\author{
By \\ Deborah A. Sage \\ A Research Report \\ Submitted in partial fulfillment of the requirements \\ for the degree of \\ MASTER OF APPLIED SCIENCE EDUCATION
}

Michigan Technological University

December 2006

Copyright (C) Deborah A. Sage 2006 
(This page is deliberately blank) 
This research report, Inquiry and Understanding: Educational Research with Middle Level Science Students, is hereby approved in partial fulfillment of the requirements for the degree of MASTER OF APPLIED SCIENCE EDUCATION at MICHIGAN TECHNOLOGICAL UNIVERSITY.

DEPARTMENT or PROGRAM:

Department of Education

APPROVED BY:

Thesis Advisor

Typewritten Name Dr. William L. Yarroch

Department Chair

Typewritten Name Dr. Bradley H. Baltensperger

Date $\quad$ December 6, 2006 
(This page is deliberately blank) 


\section{Table of Contents}

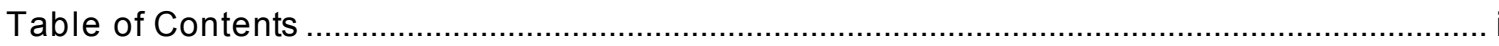

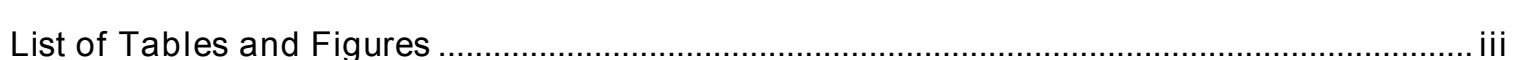

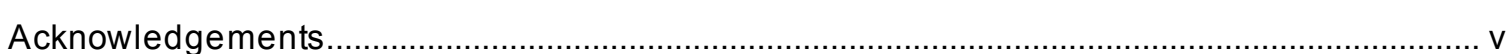

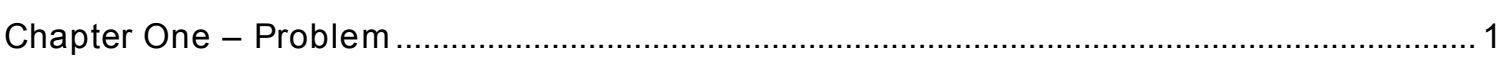

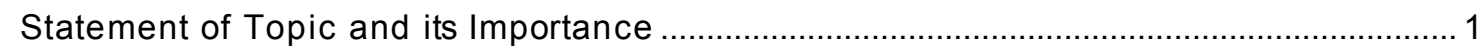

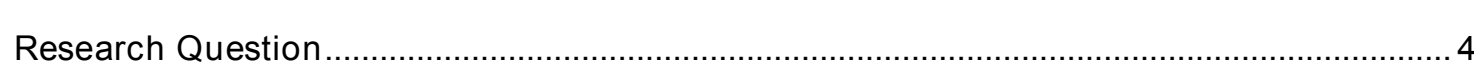

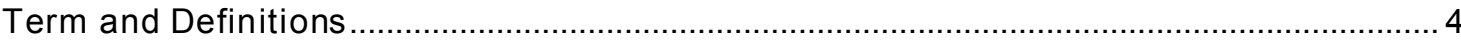

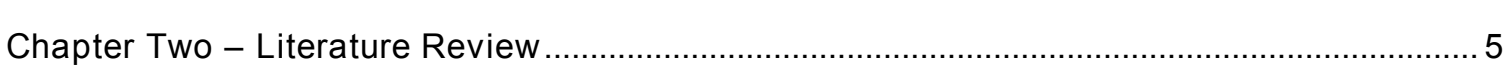

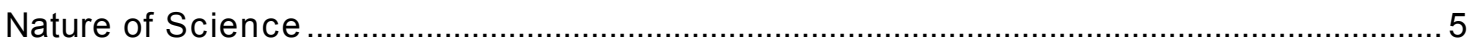

Scientific Literacy

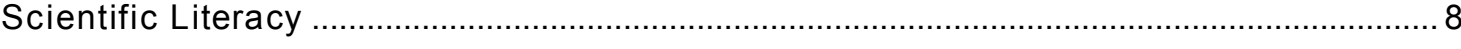

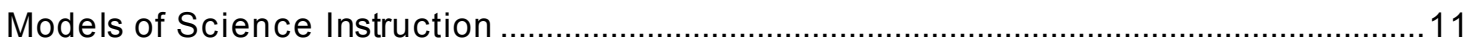

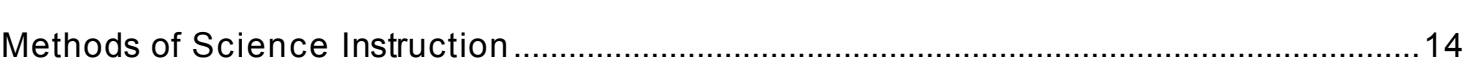

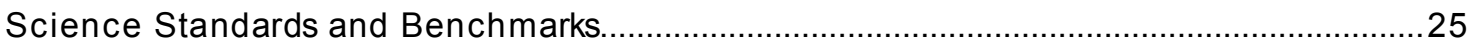

Educational Research: Attitude Measurement and Assessment 29

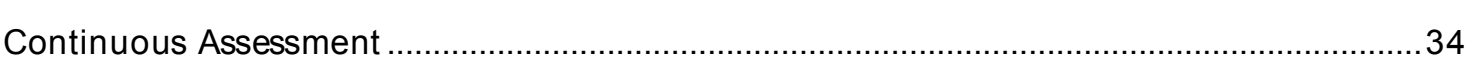

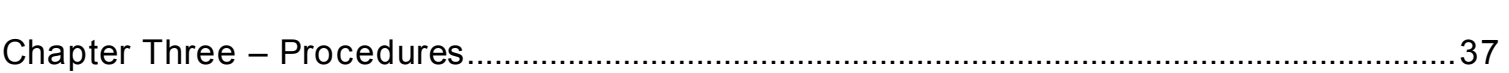

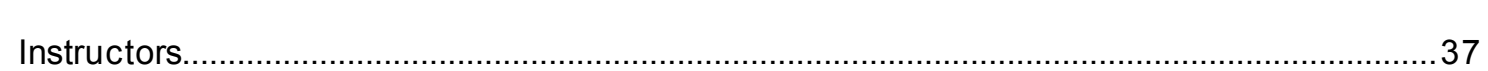

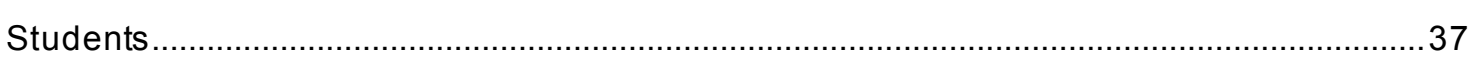

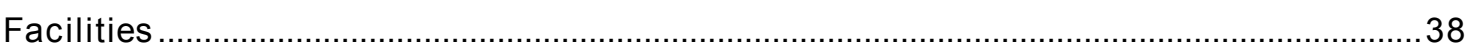

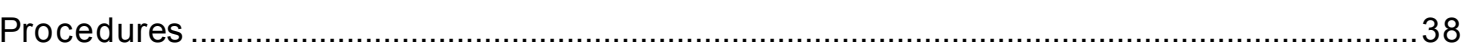

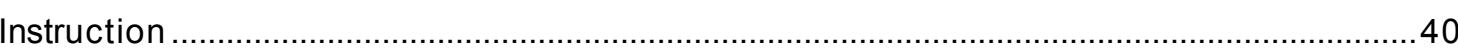

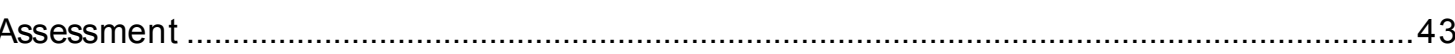

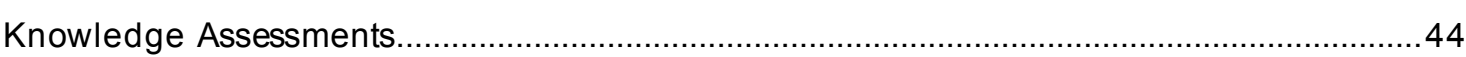

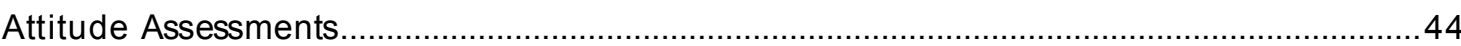

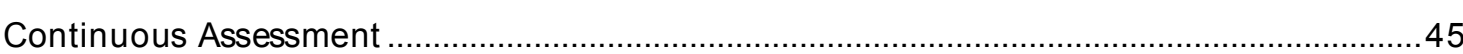

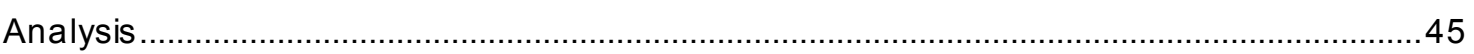

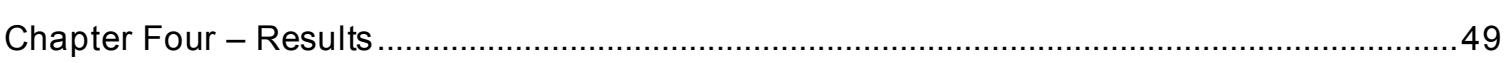




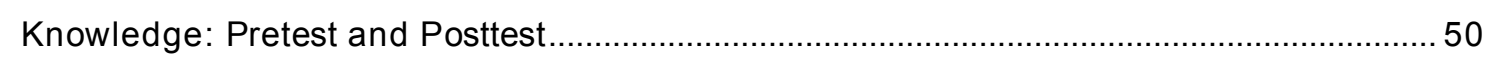

Objective Attainment: Class Averages of Assessment Scores........................................... 52

Attitude Survey: Presurvey and Postsurvey ...................................................................... 56

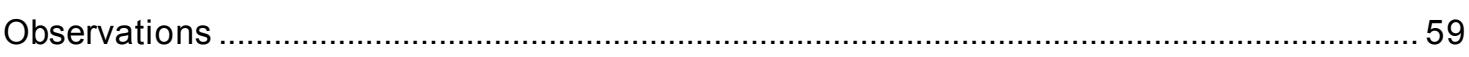

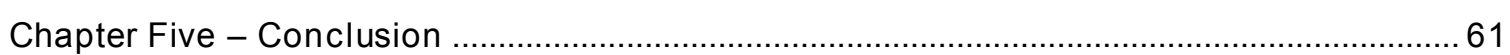

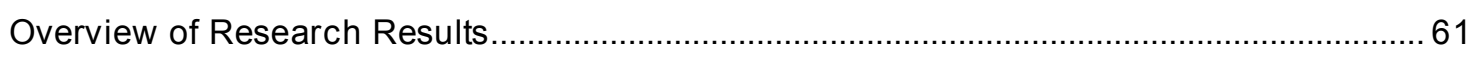

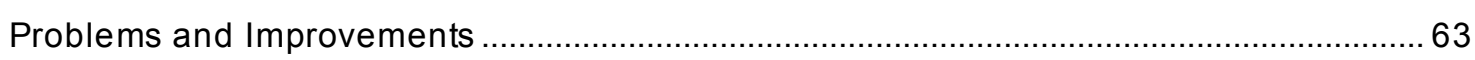

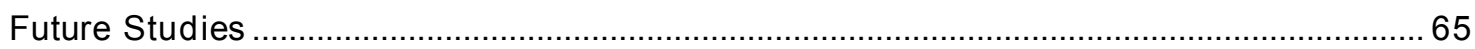

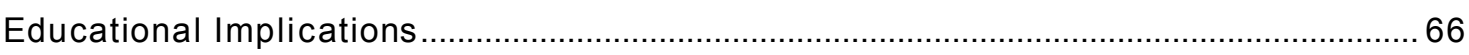

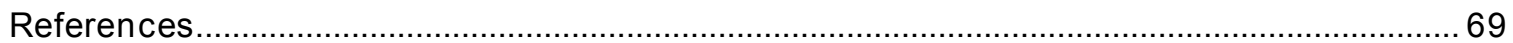

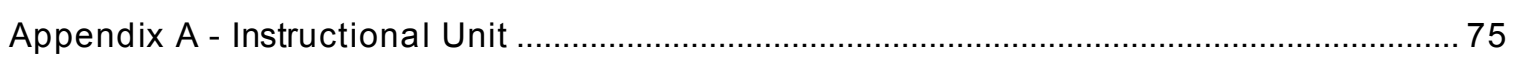

Attitude Assessment: Presurvey \& Postsurvey ……................................................................. 77

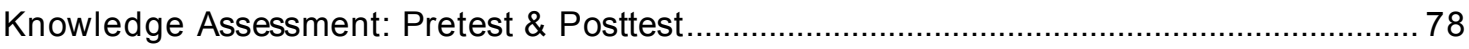

Appendix B - Tables of Results for Individual Classes ..................................................... 93

Appendix C - Water Quality Research for Dollar Bay, Michigan ........................................101

Clinical Experience in Water Quality Research ...................................................................... 103

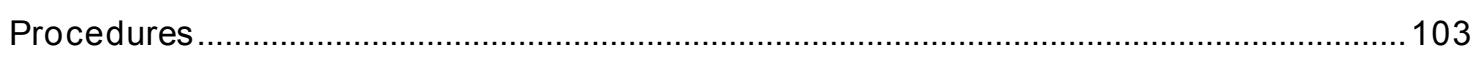

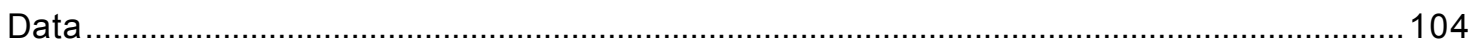

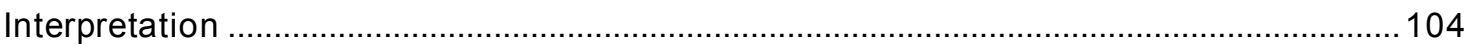

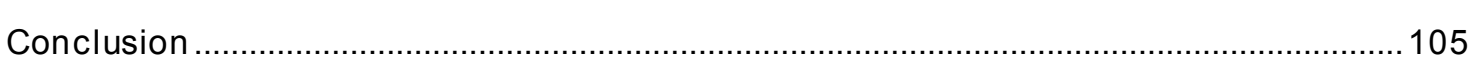




\section{List of Tables and Figures}

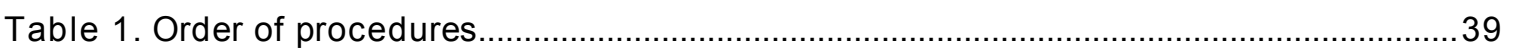

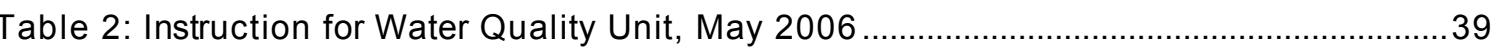

Table 3. MDE Benchmarks Addressed in the Water Quality Curriculum .............................41

Table 4. Correlate Assessment, Educational Models, and MI Benchmarks........................47

able 5. Pretest/Posttest Gains and Effect Size by Class Period ........................................50

Table 6. All Student Pre/Post Knowledge Gain and Effect Size by Item...........................53

Table 7. Average Gain in Pre/Post Knowledge by Item and Class Period ..........................54

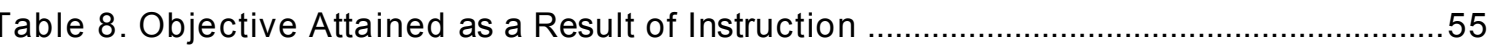

Table 9. Pre/Post Attitude Gains and Effect Size by Class Period .......................................56

Table 10. Average Gain and Effect Size for Pre/Post Attitude by Item and Class Period ....58

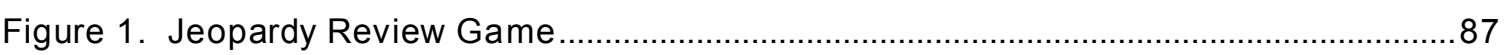

Figure 2. Student Worksheet to plot Temperature Data from Dollar Bay ............................89

Figure 3. Student Worksheet to plot Dissolved Oxygen Data from Dollar Bay ....................90

Figure 4. Student Worksheet to plot \% Saturation of Dissolved Oxygen Data from Dollar Bay

Table 11. Pretest \& Posttest Knowledge Performance of First Hour Class..............................95

Table 12. Pretest \& Posttest Knowledge Performance of Third Hour Class...........................96

Table 13. Pretest \& Posttest Knowledge Performance of Fourth Hour Class........................97

Table 14. Pretest \& Posttest Knowledge Performance of Fifth Hour Class ..........................98

able 15. Pretest \& Posttest Knowledge Performance of S.E. Hour Class...............................99

Table 16. Average Test Item Effect Size for all Five Classes .....................................100

Table 17. Stratification of Dollar Bay by Season During One Annual Cycle. ...................105

Figure 5. Temperature in Dollar Bay for One Annual Cycle ...............................................107

Figure 6. Dissolved Oxygen in Dollar Bay for One Annual Cycle .......................................108

Figure 7. Percent Saturation of Dissolved Oxygen in Dollar Bay for One Annual Cycle ....109 
(This page is deliberately blank) 


\section{Acknowledgements}

Thank you to Dr. William Yarroch, my advisor, who guided my effort on this project with a keen eye for detail and dedication as an educator.

Thank you to Dr. Martin Auer for the research opportunity and for your guidance during my internship experience with the water quality of Dollar Bay.

Thank you to Dr. Brad Baltensperger for your guidance and words of encouragement during moments of uncertainty.

Thank you to my science students at Houghton-Portage Middle School, whose participation and willingness to learn allowed me to learn along with you as we "try something different" during the water quality unit. You feed my enthusiasm for teaching. Thank you to my "lunch friends" for abundant laughter and a kind ear.

A special thanks goes out to Theresa Legg, my sister, co-implementer, and "editor", whose suggestions were invaluable.

Each of my family members deserves special recognition for unending love and encouragement during this endeavor: many sacrifices of time ensured my success. This work is dedicated to Douglas, my supportive husband, and Russell, my reason for completing this project. 
(This page is deliberately blank) 


\section{Chapter One - Problem}

\section{Statement of Topic and its Importance}

Science is sometimes thought of as appropriate for selective audiences, but science really is important to everybody; therefore, understanding science is useful to each individual. For some children, perceptions change from being like scientists at elementary level to believing science is not for them at secondary level of education (Jarvis \& Pell, 2002). Sometimes students feel that they are not a 'science person' even though they may enjoy learning about various disciplines of science. Some students studying science experience frustration as they try to use complicated vocabulary and understand difficult concepts. Frustration with science concepts often results in the perception of inadequacy or inability to understand science. Consequently some students learn to view science as an irrelevant, cumbersome requirement. These students should view science as pertinent, applicable, and understandable. How educators approach the subject greatly influences how students understand concepts and student views about learning science (Moore \& Foy, 1997; Freedman, 1997).

Experience during K-12 education often consists of learning knowledge rather than learning by developing connections that lead to deeper understanding and application of concepts. Students should be encouraged to experience science not only to view themselves as scientists but also better understand and enjoy science (Freedman, 1997; Rutherford \& Ahlgreen, 1990). Science students should have experience with conducting investigations, that promote critical thinking and logical explanation through discovery (Rudolf, 2005; Rutherford \& Ahlgreen, 1990). Setting an investigation foundation in the 
early grades permits enjoyable and constructive science experiences (Jarvis \& Pell, 2002). This continues in the middle level, where students should be able to plan and conduct investigations on their own (AAAS, 1993). Middle level students should be able to manipulate information, make observations, analyze data with computations and estimations, communicate findings by explaining what the data means, and respond with critical thinking skills to explain any problems in the data (AAAS, 1993; MDE, 2000). "Instruction which promotes a positive attitude toward science will improve achievement” (Freedman, 1997, p.344). Ideally, classroom instruction incorporates activities where students are active, involved learners dealing with real-world examples of concepts. "Instruction that makes science more exciting and encourages students (in the laboratory) has a positive influence on students' attitude toward science and their achievement" (Freedman, 1997, p.344). Incorporating research into classroom instruction provides opportunities for students to experience real-world applications of concepts presented in class. Therefore, learning concepts becomes more meaningful as students are actively involved in applying knowledge to their immediate surroundings and life experiences.

Research into science attitudes is important because attitudes are conveyed to others, influence cognitive development, and future experiences, such as independent learning and enrollment in science courses or aspiring for a career involving science (George \& Kaplan, 1998, p.96). Unfortunately science attitudes are not fully understood and those interested in encouraging interest in science need to bridge "gaps in our understanding of science attitudes" (George \& Kaplan, 1998, p.96). 
Capturing interest in science with younger students results in long-term impacts on citizenship, policies, and future career decisions. "There is a need to overcome the shortage of scientists and technologists as well as enable young people to be informed citizens" (Jarvis \& Pell, 2002, p.979). "Scientifically literate people are better able to understand and participate in discussions about issues of our rapidly changing technological world" (Jarvis \& Pell, 2002, p.980). Additionally, students pursuing college education into a career in science usually decided to do so by the end of middle school (Pell \& Jarvis, 2001, p.860).

The need to reverse the rejection of science by a large population of pupils, particularly girls, has been the subject of considerable debate. While a number of factors have played a role, it appears that the primary years of schooling are significant. ...The junior years are the critical ones for a child's formation of attitudes to science. (Pell \& Jarvis, 2001, p.860)

Research modeled by the teacher can help students apply knowledge. During an internship conducted between March 2003 and February 2004, I investigated changes in stratification of water in Dollar Bay, located in Houghton County, Michigan. The internship focused on changes in temperature and dissolved oxygen concentration during one annual cycle. Data from the internship was used as real-world application of inquiry. Therefore the goal of this project was to apply real-world examples from scientific research to classroom instruction in order to facilitate the learners' mastery of concepts. Although various teaching models and methods could achieve this goal, classroom instruction followed the Mercedes model for teaching and learning (Gallagher, 2000). 
Instruction addressed specific state and national standards and benchmarks, and included methods of teaching for understanding and inquiry methods to achieve this goal.

\section{Research Question}

1. Can middle school students attain specific state and national standards concerning 'water quality' using an inquiry-based instructional approach? Dependent Variable: attainment of specific state and national standards Independent Variable: inquiry-based instructional approach

2. Does an inquiry-based instructional approach in a real-world water quality unit improve student attitude towards science?

Dependent Variable: student attitude Independent Variable: inquiry-based instructional approach

\section{Term and Definitions}

Inquiry: $\quad$ An active investigative process; can be 'partial' or 'full'.

Partial inquiry: Investigative activities that require teacher assistance: The teacher facilitates and promotes structured discovery process.

Full inquiry: Investigative activities that promote student involvement with minimal teacher assistance.

Guided inquiry teaching: Instruction of students through teacher-led investigations where answers are known to the teacher (Furtak, 2006, p.454).

Understanding: Building knowledge with connections and applications.

Scientific literacy: Scientific knowledge and fundamental skills for science, mathematics, and technology. 


\section{Chapter Two - Literature Review}

Educational methods, geared toward inquiry and understanding, are tools to improve learning, apply different facets of learning, and address key concepts outlined in state and national standards and benchmarks. Educators attempting to improve notions that science is too difficult to understand can begin by implementing teaching units geared toward understanding basic concepts as they relate to each individual student. Teaching units, focused on activity and observation, promote relevant connections of science concepts for students. More importantly, teachers should "sustain the curiosity of students and help them develop... skills and understandings" (NRC, 1996) that students need in the 'real world'. Recapturing the natural curiosity of youngsters is the essence of inquiry. This is a difficult thing to accomplish in classrooms because students have such different backgrounds, interests, confidence levels, problem-solving skills, and motivation. Some students fail to carry out challenging problems and refuse to try to work through difficult problems. However, "Students recognize that they are capable of tackling harder problems" (NAS, 1998).

\section{Nature of Science}

The nature of science refers to how scientists learn and understand the real world and do their work by applying scientific knowledge (Rutherford \& Ahlgreen, 1990). Three aspects regarding the nature of science are distinguished (NAS, 1998). First, scientific concepts rely on more than common sense; observations are necessary as scientists consider other explanations. Second, scientific explanations should be re-evaluated to 
make accurate conclusions. Third, although individuals are given credit for scientific contributions, scientific discoveries are inevitable given time, opportunity, and inquiry (Gallagher, 2000).

Scientists understand the world by applying rules and recognizing those rules are subject to change along with revisions of ideas and theories. Although scientific views may change, modifying these views is normal because scientific views often include some uncertainty. Certain questions cannot be answered scientifically, which means individual beliefs can neither be proved nor disproved. Either way, these informed views are validated before scientists share the information.

Secondly, scientists may not have all of the information needed, which means they must make the best conclusion possible with the information that they have at the time. The resulting theory may lead to misunderstanding scientists' discoveries and views because non-scientists may not be aware that a theory in science is supported with facts obtained through a rigorous investigation. A theory in layman's terms may not be subjected to a rigorous process: a theory is often equated with a hypothesis, and receives no further attention. In order for the science community to obtain the public's approval, it is often necessary to educate the public on the process scientific theories go through before they are afforded a measure of validity. Consequently, education starts to bridge the gap between the meaning of scientific vocabulary, and the meaning given to the same vocabulary by the general public.

Lastly, the nature of science also encompasses intellectual and social aspects as science is integrated with other subjects (AAAS, 1993). Scientific knowledge that is practically applied ensures deeper understanding about how the world works. This is where the 
nature of science affects how common people, or 'non-scientists' learn about the world. Non-scientists feel disconnected to scientific principles and fail to connect science to their own life. If students experience science and discuss its implications in real-world contexts this misperception eventually changes.

As students come to appreciate the context dependency of inquiry, they will be better positioned to realize the instrumental nature of science and understand the importance of public input into the question of how the tools of science ought to be used. (Rudolf, 2005, p.817)

Ideally, education would "reveal to students the fully integrated nature of all of our fields of knowledge with the social and political world in which we live" (Rudolf, 2005, p. 816). This would entail more integrated approach to include more connections. Gaining "an appreciation of science from this perspective would require the incorporation of significant amounts of historical, philosophical, and sociological material in the curriculum, all coordinated with the content and processes of the natural sciences" (Rudolf, 2005, p.816). How to attain this, according to Rudolf, is to "use the engineering activities as an explicit model for the 'pure science' inquiries" in earlier grades but "transition to abstract, disciplinary inquiries" (2005, p.816).

Problems. The nature of science is complex: all aspects are important to make connections and evaluate claims. Science is intellectual and theory driven. It is also with real-world applications such as engineering and design (Rudolf, 2005, p.805). It is portrayed through logical investigations into understanding the natural world; yet pure science, or research, doesn't always follow ideal scientific processes (Rudolf, 2005, p.806). Consequently, students learn that science is an investigative activity but miss 
relevant science content (Rudolf, 2005, p.806). These problems are perpetuated when well-intentioned educators juggle requirements, and attempt to convey understanding of abstract concepts to students who struggle with technical concepts. Hence, misunderstanding the complexity of science passes from teacher to student.

Improvements. Science is often separated into pure science (research) or applied science (engineering and design). Rather than separating science into these categories "we should acknowledge the practical nature of science in all of its forms" (Rudolf, 2005, p.810). Realistically, teachers could continue the "engineering design" activities that engage students yet offer instruction that is "contextualized" and therefore more like pure science (Rudolf, 2005, p.809). This understanding improves public involvement with policies concerning science rather than permitting "a small group of non-representative people" to decide for society (Rudolf, 2005, p.808). Hence, science education begins with knowledge and understanding of science concepts but extends into every aspect of understanding the world, daily activity, and broader decisions or policies.

Educators are challenged to integrate philosophy of science with scientific understanding of the world so that students experience science and use inquiry to investigate. By addressing the nature of science more objectively we (as scientists) understand the world by looking at changes that have occurred.

\section{Scientific Literacy}

Scientific knowledge can be used to explain and predict how things behave. Individuals become more scientifically 'literate' by understanding scientific knowledge and developing fundamental skills. Teachers can improve scientific literacy by including the 
history of science and subsequent advances in technology. This will provide additional perspective and understanding about the contributions of familiar 'great scientists'.

Discovery begins with observation both in the classroom and historically: experience and reasoning develop understanding of concepts. Thus, classroom instruction is similar to ideas constructed by scientists from previous generations (Gallagher, 2000).

Historical perspectives in science illustrate 'accidental' discoveries made by famous scientists, which can fuel children's natural curiosity (Rutherford \& Ahlgreen, 1990). Some discoveries in science become key breakthroughs, opening doors for future discoveries that result in major scientific and sociological changes. Many scientific discoveries lead to developments in technology, which initiates a sort of 'snowball effect' between developing science and technology. Once they become better understood these discoveries are sometimes taken for granted. For example, students reading about Newton's major breakthrough discovery called gravity may think it absurd that nobody knew about it then. Understanding history and the perspectives held by individuals of that time frame focuses explorations in subjects based on student curiosity. History and philosophy of science connects with teaching objectives because students need to learn about the nature or culture of science while learning about the discipline of science. Students can be encouraged to appreciate science by providing alternative contexts such as historical perspectives for the scientific concepts and the cultural, ethical, political, and economical influences (Matthews, 2000, p.12). Philosophies of science help connect with teaching science because the meaning of words and concepts within the content area will change over time. Scientists are philosophers, continuously reflecting on concepts and revising thoughts and theories. The history of science is not 
taught as often or in as much detail: "Science might be the only place where students may encounter history..." (Matthews, 2000, p.xxvii). Social science curricula currently deal with the roles and contributions of Galileo and other scientists in history. Students will understand historical perspectives alone, even though history has been incorporated in other subject areas. Students may be able to more directly understand the scientific experience underlying the concepts learned with historical perspectives. Hence, the history of science is important to know because it can help us understand the scientific principles used and accepted today. Students and teachers often accept the principles without questioning the discovery and validation of the principles. Scientists generally improve ideas and truths set forth by preceding scientists. In this way, science has grown and become more sophisticated. We can see this in the current curriculum taught in our schools; scientific concepts are taught at earlier educational levels in the current generation than in earlier generations.

Historical perspectives also alter societal norms due to the endless impact of scientific discoveries on society. Science and technology shape society (Rutherford \& Ahlgreen, 1990). Sociological and cultural influences resulting from science, mathematics, and technology contribute to society and also affect how problems are interpreted and solved. Science provides basic principles and knowledge to help understand the world. Scientists use these principles in practical applications and designs. These applications and designs influence development of new technologies, which then shape society. Discoveries lead to theories, which change over time; they result in recommendations for the public, who then incorporate current scientific knowledge and scientifically sound research-based 
recommendations into their lifestyles. Engineers are a prime example of scientists relating science, mathematics and technology to solve problems and shape society. Knowledge is extended as scientists engage in further investigations, especially as new technologies become available. These changes create difficulty for non-scientists, particularly if individuals are unable to understand why the changes occurred. Similarly, students may have difficulty accepting disclaimers in scientific knowledge. Yet students accept changes when presented a time line of discoveries and revisions of known discoveries as scientists continue to investigate, evaluate, and utilize technology.

\section{Models of Science Instruction}

Achieving understanding depends on how students learn and apply knowledge.

Education has traditionally promoted rote memorization of knowledge and facts that students were expected to recall. Teachers passed on knowledge through lecture style of instruction, which does not actively involve students in the learning process. Although this type of instruction accomplishes the task of relaying information, students tend not to identify or apply it; consequently, students tend not to truly master understanding the information. Students learn better by frequently applying knowledge to real world situations and to other science lessons (Chang \& Mao, 1998; Chinn \& Hmelo-Silver, 2002; Germann, 1991; Phillips \& Germann, 2002). Often students and teachers fail to connect current concepts with other concepts taught in science, making the subject more linear than it really ought to be. Acknowledging science is applied everywhere leads to recognition and appreciation of its impact in real world situations, as promoted by 
educational models such as the Mercedes model (Gallagher, 2000) or Wiske's model (Wiske, 1998).

Educational models are used to explain the process of understanding. Sometimes teachers believe they are meeting the objectives when in reality they are missing an approach that would educate more effectively. Educational models such as the Mercedes Model or Wiske's Model improve upon current practices. These models focus on encouraging students to personalize information in order to better understand it. With continuous assessment teachers are better able to gauge each student's understanding, remedy misunderstandings, and re-teach when necessary to achieve deeper understanding. This is referenced in the Mercedes Model for teaching and learning. Mercedes Model. The Mercedes Model for teaching and learning has three distinct parts centered within continuous embedded assessment. The three parts are: Building a knowledge base; Developing understanding by making sense and making connections; and Applying knowledge, which includes practical applications, applications for understanding and applications for future learning (Gallagher, 2000). It is designed to assist teachers in determining which activities would be most appropriate to accomplish specific learning objectives.

1. Building a knowledge base: includes lectures, reading, labs, videos, vocabulary, review questions, and testing.

2. Developing understanding: includes concept mapping, open-ended written responses, connection-making tasks or activities, presentations requiring explanations, analytical vocabulary, and essay responses on evaluations. 
3. Applying knowledge: includes searching for applications, open-ended questions regarding applications, presentations that explain science principles, and tests involving applications.

Wiske's model. Wiske outlines four parts of a framework to teach for understanding: generative topics, understanding goals, performances of understanding, and ongoing assessment. Each of the parts is interconnected during the application of the model, invoking aspects of the others in a cyclical, reflective process (Wiske, 1998, p.62). The different elements are repeated in the process, but they need not be practiced in any specific order.

1. Generative topics: include themes that outline and are usually central to the domain, interesting to the students, exciting for teachers, and easily connected with other topics (Wiske, 1998, p.64). With these criteria, teachers are better able to design a curriculum containing generative topics and effectively illustrate them with the use of concept maps. Rather than outlining themes in a subject to be taught, the use of 'understanding goals' clearly states what students are to learn and understand through inquiry. This enables teachers to focus on concepts that are specific and relevant to the subject studied as well as evaluating actual student performances as described in the goals. Goals should also be long-range so understanding can become more specific over time.

2. Performances of understanding: include three fundamental actions during instruction. Messing about, which is used in the beginning of a unit to help students connect the unit to their own experiences; Guided inquiry to engage students in using central ideas that achieve understanding goals, and Culminating performances that are final products used to complete a unit. 
3. Ongoing assessments of performances: used to assess understanding. Assessments are automatic when instruction is effective because the learner continually compares where they are to where they were, and then looks to where they want to be (through the use of understanding goals). Rubrics are a useful tool of assessment since it is difficult to have a complete outline for evaluating in advance. Teachers and students must share the responsibility for ongoing analysis progress students make towards achieving high-level performances.

\section{Methods of Science Instruction}

Educational methods such as Teaching for Understanding and Inquiry challenge students to become active, involved learners. Both methods engage students, promote active involvement from students, and increase interest and enthusiasm for all fields of study. Students become personally involved with the content matter as they discover concepts for themselves through activity. This also enhances students' ability to more effectively relate concepts to life experiences. Both teaching for understanding and inquiry actively involve the student in the learning process and attempt to bring concepts to life for students. While teaching for understanding builds the knowledge base and then connects knowledge and experience, inquiry teaching increases the level of student involvement as students are given the responsibility and freedom to investigate problems in a classroom setting. Inquiry-based instruction works when teachers "begin the lesson with scientific rationale... they respond with some kind of justification of their withholding the answers... and using methods and thinking processes that scientists might make" (Furtak, 2006, p.465). 
Teaching for Understanding. Teaching for understanding occurs when education is geared for students' comprehension of concepts while learning in the classroom setting. Understanding is difficult to define, as it is a goal that educators aim to achieve.

Therefore, understanding in science is explained through various measured assessments such as standardized tests, tests administered by teachers, and lab activities that require the use of skills. The current definition of understanding in science incorporates activitybased learning that focuses on discovery rather than rote memorization of facts. Science applies to authentic situations and therefore should be presented so that students can see the relevance of what they learn and make applicable connections. Information and concepts should be dismissed from the curriculum if there is no real-world significance (Wiggins \& McTighe, 1998). Likewise, skills should be included in the curriculum only if the development of those skills improves the students' future: skills students need to ensure productivity as an adult.

Teaching for understanding often uses activities that include guidance as students discover concepts in any subject area. As part of this guided learning process of teaching, continuous assessment is utilized for feedback. The practice of continuous assessment helps students by alerting teachers of problems early on in the instruction sequence. Teachers respond by re-teaching the concepts, then on to new ones as students demonstrate understanding. Students use their knowledge of the concepts while teachers provide opportunities and activities to assist students in making those connections (Wiske, 1998; White, 1992). Activities should not be 'recipe' labs where students expect certain results before they begin. Students are encouraged to make predictions about what they think will happen throughout the experiment, modeled by the scientific 
method. This can be difficult for many students, but it is the responsibility of the teacher to encourage students to think, predict, and problem-solve.

Six Facets of Learning. Understanding is characterized by the following facets: explain, interpret, apply, perspective, empathize, and self-knowledge (Wiggins \& McTighe, 1998). Each facet deepens with the use of questioning, inquiry, reflection, discussion, and application. The facets help in the learning process, particularly as students reshape beliefs while achieving deeper understanding, personal commitments in the form of questioning, applying, replying, and structuring beliefs. This characterization of understanding incorporates a philosophical view rather than a 'textbook' explanation. This explanation is more realistic because it focuses on understanding from an educational approach. Since understanding is such a broad topic, it could be interpreted many ways depending on personal style of the educator. Incorporating facets of learning into the educational process creates a learning environment focused on deeper understanding of concepts rather than simply conveying knowledge from teacher to students. This facilitates students to achieve an authentic understanding when learning. 1. Explanations: understandings that rely on knowledge of why and how things occur, not just the possession of knowledge (Wiggings \& McTighe, 1998, p.45). This facet suggests using assignments and assessments that require an explanation with details to indicate what the student understands, whereas tests are less effective representations. Explanations provide better ways to gauge student understanding through justifying responses or course of action (Wiggins \& McTighe, 1998, p.85). Students can be interviewed individually with oral exams or in groups through question and answer sessions. Other performance tasks provide insight regarding what is understood or 
specifically misunderstood. Students should also demonstrate progression from novice to expert in the particular content area.

Science is predominately based on explanations that need to tested and proven.

Therefore, students should be provided opportunities to explain in order to realize the importance of thoroughly explaining their predictions, observations, and theories.

Teachers need to establish the importance before the lesson progresses by designing curriculum around asking questions repeatedly until students make important connections. Concept maps are a useful method for instruction and evaluation in this particular area, especially when students need to explain themselves using the connections they made in the maps. The problem with this approach lies with the importance of writing abilities to realistically portray understanding. This method is a better indicator of understanding than standard tests despite the difficulty assessing students who do not write well but clearly explain the concepts through discussion. 2. Interpretations: important demonstrations of understanding in science. They focus on stories for translating information (Wiggins \& McTighe, 1998, p.48). Students should acquire the ability to weave together a story that is "coherent, illuminating, and substantiated" (Wiggins \& McTighe, 1998, p.89). That story should then be used to assess the students' understanding. Interpretations are challenging because the reader of the stories should be engaged while selecting main points from the selection they are reading. It is difficult to determine how engaged a student is even when they correctly interpreted the meaning of the reading, especially with scientific information. Students can show understanding of given scenarios by illustrating their understanding through drawings, mapping relationships, or creating fortune lines (White, 1992). 
In order to interpret meanings clearly students need structure and guidance: rubrics area a very good way to provide that information. Students should be able to make associations based on what they have learned, realizing they do not need to become experts on a topic in order to interpret meanings. Often, students seem to look for the correct responses rather than realizing they can make sense of information differently than others and still be correct. Additionally, students should recognize that certain interpretations have more meaning than others.

3. Application: uses what students have learned and applies it in a new situation (Wiggins \& McTighe, 1998, p.51). Applications are done with an overall goal, such as to solve various problems. Tasks and rubrics should be utilized when determining how well students have mastered skills, knowledge, and performances important to understanding. As students get feedback they should adjust responses and continue to respond intelligently while making self-adjustments.

Various performances are naturally used throughout many lessons in science. Often, the ability to apply knowledge is confused with 'good performance' on an activity that requires the use of that knowledge. Students may not have the skills necessary to complete tasks even though they may understand the concepts. Science is best understood through active investigation, or inquiry, which provides ample opportunity for teachers to incorporate tasks for assessment. Understanding is best achieved through teaching others what you know. Consequently, the ability to monitor oneself while learning indicates the extent of that individual's understanding.

4. Perspective: includes objective, critical, and insightful viewpoints that expose assumptions, conclusions, and implications (Wiggins \& McTighe, 1998, p.53). 
Achieving perspective allows individuals to look at theories, problems, or opinions differently by asking how others may view the same information.

Perspective is a challenge to individuals who find the 'right' answer rather than looking for many possible explanations. Teachers can gain perspective of how well students understand by using embedded assessment throughout the instructional unit.

5. Empathy: similar to perspective by grasping another point of view; however, empathy is less objective because the goal is to feel and understand something different that what you know in order to understand people, situations, information, or emotions as completely as possible.

6. Self-knowledge: involves wisdom to understand oneself before accomplishing understanding of the world around us. This facet encourages opportunities to reflect, assess, and regulate in order to improve misunderstandings of people, beliefs, or information.

Assessing students' self-knowledge requires students to evaluate their own work. Teachers can gain a more accurate view of how well students perceive understanding their work. Applications of Facet 6 include using portfolios, which provide students opportunity for review and response of their work. Posing the same question before and after a unit enables both the teacher and student to see what progress has been made. Furthermore, students should write a self-assessment of their progress to describe their understanding before and after the unit.

Unit design implied from the six facets focuses on the WHERE sequence of lesson design, which promotes greater chances for student understanding: Where are we going, Hook the students, Explore and Enable, Reflect and Rethink, and Exhibit and Evaluate. 
Even though the steps are listed in a particular order they do not need to be followed exactly in this sequence. They are only intended to test understanding in a similar way as backward design (White, 1992). Educators must also consider misconceptions and potential for faulty beliefs that affect understanding. Similarly, misunderstandings held by educators can influence student understanding and need to be addressed.

Inquiry. Inquiry teaching centers instruction on questions and investigations in an effort to guide students' discovery and understanding. More open-ended problems are incorporated into lessons and then students work to find solutions for those problems. This provides opportunities for students to experience the scientific concepts that otherwise could remain less noticed in their science textbooks. Inquiry teaching parallels the scientific method, beginning with a problem or question to investigate. The process of investigating and learning from it enhances and exhibits understanding. Inquiry is summarized best in the "5E" Learning Cycle: Engage, Explore, Explain, Elaborate and Evaluate (Stamp \& O'Brien, 2005), which strongly correspond to the scientific method. It is a "hands-on/minds-on, inquiry-based method that is effective at any level of instruction, especially for challenging misconceptions" (Stamp \& O’Brien, 2005). Inquiry is an investigative process that enables students to describe and explain scientific phenomenon. The common practice of inquiry in classrooms is, without a doubt, "positive" because students are more engaged "than typical teacher-centered instruction" (Rudolf, 2005, p.805). So, what is inquiry? It includes a wide range of activities, but can best be represented "as a continuum" of different methods of science teaching (Rudolf, 2005, p.805). 
"The continuum is bordered on one side by traditional, direct instruction in which students are told the answers they are expected to learn by their teacher. At the other end of the continuum, students design and conduct their own investigations into phenomena that are not known to the teacher in what can be called openended scientific inquiry. ...Science instruction often takes place somewhere between the extremes, where students are guided, through a process of scientific investigation, to particular answers that are known to the teacher. This version is called guided scientific inquiry teaching.” (Furtak, 2006, p.454)

Inquiry activities vary within a spectrum of teacher involvement and difficulty for the student. Chinn and Malhotra's classification of inquiry activities can be "used to evaluate inquiry tasks in school curricula" (Chinn \& Hmelo-Silver, 2002, p.172). Classroom instruction involving simple inquiry activities may actually encourage misunderstanding science because students often believe that scientific reasoning is based on simple and superficial observation (Chinn \& Malhotra, 2001, p.190). Students are misguided because instruction fails to represent the intricate nature of science and theoretical background needed by scientists. Simple inquiry, typical in most classrooms, differs from authentic inquiry in that it does not involve expanding on others' work or following "norms that provide general guidelines for scientists"(Chinn \& Malhotra, 2002, p.190). Simple inquiry in the forms of experiments, illustrations, and observations is outlined in textbooks and is typical instructional practice.

There are "six fundamental cognitive processes that scientists engage in when they conduct research: generating a research question, designing a study to address the research question, making observations, explaining results, developing theories, and 
studying others' research" (Chinn \& Malhotra, 2002, p.183-186). For authentic inquiry in classrooms, activities must be "relatively simple" yet "capture core components of scientific reasoning", and can occur "within limitations of space, time, money and expertise that exist in the classroom" (Chinn \& Malhotra, 2002, p.177). Authentic inquiry is "research that scientists actually carry out" (Chinn \& Malhotra, 2002, p.177), such as case studies and complex experiments involving multiple variables. Inquiry embraces children's natural curiosity while promoting discovery and explanations based on experience. It is through discovery that science makes sense out of the natural world; consequently, it is through inquiry that one can better understand science. Learning is something students "do rather than something that is done to them", according to the National Science Education Standards (NRC, 1996, p. 20). Students learn when they are allowed to collaborate, share ideas, form theories, and analyze theories for acceptance or rejection of those ideas (Tan, Yeo \& Lim, 2005). Therefore, inquiry is important in all fields of science as well as to all individuals. Inquiry is active learning, which means students would be actively involved in the learning process. Consequently, students should describe objects and events, acquire knowledge, question, explain, test, and communicate findings. Students should also establish connections between knowledge and investigations. They should be "exposed to the variety of inquiry approaches and be made aware that these approaches vary depending on the context in question (Rudolf, 2005, p.817).

The following approaches are types of inquiry-based teaching depending on teacher's learning outcomes for the content being taught: constructivist by explaining how students will construct knowledge during the activity; scientific by explaining how students are 
like scientists during the activity; withholding information to get students to discover answers; expected results are revealed as confirmation to students throughout the activity (Furtak, 2006, p.458).

The Michigan Curriculum Framework (MDE, 2000) outlines standards and benchmarks for continuous development of understanding, described in action goals, such as to describe, explain, identify, interpret, justify, communicate, develop, design, and construct (MDE, 2000). By initiating inquiry in the classroom, students become active, involved learners with deeper understanding of science concepts (Margerum-Leys, Fishman \& Peek-Brown, 2004) and higher scores when required to apply or synthesize knowledge (Chang \& Mao, 1998).

Inquiry activities should engage students in partial inquiry or full inquiry depending on the level of schooling involved. Partial inquiry requires more teacher assistance throughout the process. Full inquiry requires more student involvement, and the teacher assists when necessary. It allows for students to use knowledge, observations, ideas and questions. With inquiry, students have the opportunity to recognize relationships between explanation and evidence, and then relate the background knowledge and theories guiding investigations. Realistically, students will encounter difficulties during the process, which means sometimes students will need assistance. For example, students struggle with narrowing a key question to investigate and then planning the experiment. Many middle school students also have problems differentiating between experimental variables and how each variable affects experimental results. Teachers are able to assist students and then allow students to continue investigating, guiding students through points of confusion. Although this is technically not full inquiry it does permit 
students to maximize their independence throughout the investigation and make their own connections during the investigation.

Since the scientific method involves structured procedures, students may be more comfortable engaging in discovery. Often middle school students seek 'the answer' in the form of one solution for the problem. Despite determining a solution, it may not be fully understood. Students engaging in inquiry activities understand better because they see how things work and then test working theories about phenomena. This is comparable to an image of a young child learning about the world for the first time, not having the knowledge base to understand but having the curiosity to find out.

"Science instruction that includes a regular hands-on laboratory experience is a viable and effective instructional method for science teachers" and when it is "hands-on" it improves "achievement levels and promotes positive attitudes toward science". "The hands-on laboratory has been... an effective and workable technique for science teachers to motivate their students by improving their attitude toward science and by significantly affecting their achievement in science knowledge" (Freedman, 1997, p.354).

Inquiry depends on students discovering concepts or theories and then explaining how something works based on experience. Student exposure to a research application illustrates inquiry with the scientific method in a real-world investigation while reinforcing pertinent concepts.

The Learning Cycle, also known as "5E” (engage, explore, explain, elaborate, evaluate), loosely resembles the scientific method because it is a "hands-on/minds-on, inquiry- 
based method that is effective at any level of instruction, especially for challenging misconceptions" (Stamp \& O'Brien, 2005).

Promoting mastery in education applies inquiry experience that includes observing, referencing information, investigating, interpreting data, explaining, and communicating results. This essentially is the scientific method, a useful tool for scientific problem solving. Although the scientific method and inquiry are similar and interconnected, the approaches are slightly different. Inquiry tends to be less structured and therefore allows students to figure things out without as many limitations in procedures, yet it could become open enough for students to venture on a serendipitous journey. On the other hand, the scientific method has a more structured and specific format to follow in order to familiarize students with a procedure for investigating. Some students seem to believe these steps are the only way to understand their observations, rather than using these steps as guidelines for organizing the investigative process.

\section{Science Standards and Benchmarks}

Inquiry is in the content standards for all educational levels of learning (NRC, 1996). General standards expect inquiry at all education levels to become more sophisticated as individuals integrate concepts. Inquiry is much like the scientific method; therefore, middle school students are able to perform investigations and then develop descriptions, models, or predictions based on results acquired. Middle level students should not only be exposed to the scientific method but should also apply it, according to the Michigan Framework (MDE, 1996) middle level students are also expected to determine 
relationships between information while reflecting on relevant information. This includes applying mathematics to form patterns and relationships from evidence. Investigations teach by example, as scientific experiments follow the same general process that the students are expected to follow with inquiry activities. For example, middle level students at Houghton Middle School are engaged in designing their own investigation, following the scientific method, and scientifically presenting their findings. Students follow this process as outlined by the Western Upper Peninsula Center for Science, Mathematics and Environmental Education (WUPCSMEE, 2005). Students learn by inquiry and deepen understanding when experimenting. Just as with 'real' scientists, curious students will notice something and persistently question until they solve the initial question. This is the same as investigating with the scientific method: initiate a question and then discover an answer for the problem.

Historically, inquiry centered on acquiring information and communicating through the 'language' of science. This view was practiced until about 50 years ago when science teaching and learning began to incorporate evidence to be investigated and then explained. “In the 1960's primary schools were encouraged to develop children's science process skills" which advanced in the 1980's to "increase the number of primary schools that included science activities in the curriculum" (Pell \& Jarvis, 2001, p.848). During the 1990's standards brought about improvements in science teaching, which has resulted in national improvements in science achievement scores (Pell \& Jarvis, 2001, p.848). Standards and benchmarks for education have since been established at state and national levels to incorporate teaching with inquiry. Although variations exist among state guidelines, generally state and national standards aim to accomplish similar educational 
goals. Educational standards incorporate inquiry as an essential component in the science classroom. Inquiry in the content standards includes necessary abilities and understanding. Students should be able to question, predict, investigate, explain, and model in order to understand science better. Analyzing and communicating ideas are essential skills, and students should be able to utilize tools and technology while accomplishing these skills.

"Existing science standards provide pointers but do not provide detailed analyses" of authentic inquiry (Chinn \& Hmelo-Silver, 2002, p.172). Students typically are not asked to control variables because activities involve outlined procedures. Authentic inquiry promotes students developing and practicing more complex scientific skills that include more complex reasoning, such as critically thinking about multiple variables and analyzing results from investigations (Chinn \& Malhotra, 2002, p.200). Instead of modeling actual scientific investigations, students often are directed to make simple observations, but fail to "transfer data", address flaws in the experiment, or identify bias affecting results (Chinn \& Malhotra, 2002, p.200).

The NRC supported the change of focus in science classrooms and provided suggestions in their educational objectives (NRC, 1996). Awareness of this historical account provides additional perspective and credibility to the current standards by illustrating where the current standards originated. Standards suggest introducing formal explanations of scientific principles after student experience hands-on activities. Readings, reports, interpretations of data, and debates enhance student involvement and understanding. The National Science Educational Standards (NSES) include inquiry guidelines that involve observing, questioning, referencing information, and thinking 
through logical explanations (NRC, 1996). The categories include physical and life sciences, earth and space, science and technology, science in personal and social perspectives, and the history and nature of science. Students partaking in the activities develop the ability to understand science through experience rather than recognizing science with exposure. The NSES state that science is for all students, which means all students should be challenged to observe and explain their world according to scientific principles. The NSES presents inquiry in all fields of science as well as to all individuals: inquiry and the scientific method are useful for individuals of any age, race, gender, or ethnicity. Both the scientific method and inquiry are used to understand the world around us by incorporating a level of active involvement from the learner as the learner determines causes and effects of events. This is accomplished using prior knowledge, investigating to acquire new knowledge, and then concluding with explaining how and why events occur.

The NSES are used as a model in order to outline specific objectives required of each student at each stage of educational development. They reform education by creating a common guideline for student progress and performance. Each content area begins with a vision statement to outline the main objectives for that area of study. The science standards have five content strands, which are broad topics broken down into smaller, more manageable categories. The strands are numbered by roman numerals and have various content standards to form smaller categories, which are then broken down into even more specific components for each educational level (elementary, middle school, and high school). Within each smaller component there are specific key concepts along 
with examples of real-world contexts to better illustrate the objectives. The focus is to achieve better understanding of main concepts listed throughout the content standards. The Michigan Curriculum Framework document outlines outcomes and concepts students need to master. These standards address continuous development of understanding in action goals such as to describe, explain, identify, interpret, justify, communicate, develop, design, construct. They also assist public and private schools in providing a quality education for all students by setting standards and defining the core curricula to be used. The focus is mainly on real-world applications of knowledge that enable all students to achieve a fulfilling and productive adult life. By using school improvement techniques, content standards, and student achievement information the Michigan Curriculum Framework hopes to improve student performance and the quality of education in Michigan.

Concepts addressed in the middle level science content area of the Michigan Curriculum Framework Standards and Benchmarks (MDE, 2000) are listed in Table 3. Specific water quality objectives are included in the Earth Science content standards:

Strand V. Using Scientific Knowledge in Earth Science

Standard V.2. The Hydrosphere: All students will demonstrate where water is found on Earth; describe the characteristics of water and how water moves; and analyze the interaction of human activities with the hydrosphere.

\section{Educational Research: Attitude Measurement and Assessment}

Success with inquiry varies from instructional approaches, mainly by appropriately challenging students and generating interest in science. The importance of inquiry at all 
educational levels is supported by research involving attitude and achievement tests. Student-centered learning applying inquiry techniques have been used for many years: "Summaries of research in science education since the 1970's report that hands-on, minds-on, activity-based laboratory instruction enhances students' attitude toward science" (Freedman, 1997, p.344).

Research correlates motivated students with higher achievement and more positive attitudes. Studies pertaining to inquiry indicate that, regardless of grade level, student performance and attitudes toward science improve when instruction focuses on inquiry activities (Freedman, 1997; Misti, Shrigley \& Hanson, 1991; Shymansky, Hedges \& Woodworth 1990). Research indicates this is true for elementary or secondary students and for either gender (Pell \& Jarvis, 2001). Positive attitudes in elementary ages affect achievement and desire to learn science in later years (Moore \& Foy, 1997; Pell \& Jarvis, 2001).

Children appear to like the co-operative practical hands-on aspects of science where they choose equipment and find out what happens. However they are not so keen on working out how to set up the investigation or finding out why results occur. Children also much prefer the teacher telling them what to do compared to working out what to do by themselves. ...The most common feature that attracted (11-14 year old children) was the amount of practical work and the opportunity to work with others. (Pell \& Jarvis, 2001, p.853)

Thus, inquiry-based teaching is beneficial to student learning, provided students receive necessary guidance to ensure learning objectives are accomplished accurately. Teachers 
either accept correct conclusions or reject misconceptions by questioning students and redirecting investigations (Furtak, 2006).

Attitude. Measurement and assessment of attitude provides insight into aspects of learning other than achievement alone. Various factors affect attitude and achievement: they are difficult to isolate when determining the cause of effective gains in attitude and achievement. "Well motivated pupils with low anxiety levels made higher cognitive gains" especially for "those pupils with an initially positive view..." (Jarvis \& Pell, 2002, p.995). "Attitudes are learned and so the influence of others is a key factor in the development of students' attitudes toward science" (George \& Kaplan, 1998, p.94). Yet science educators attempt to motivate students by assessing interest and views and by “differentiating among attitudes, beliefs, and values" (Moore \& Foy, 1997, p.327). The Likert scale is an assessment tool that educational researchers can use to qualify attitudes (Moore \& Foy, 1997; Pell \& Jarvis, 2001). It rates attitudes on five levels of 'agreement'; each has been given numerical value (Mills, 2003, p.65). With the Likert scale, 'strongly disagree' is noted as most negative (-2) whereas 'strongly agree' is noted as most positive $(+2)$. Resulting scores on the survey indicate a continuum of attitudes as positive or negative. This is an authentic assessment used by the teacher to illustrate levels of positive or negative attitudes. Generally, positive attitudes correspond to work involving computers, experiments, and reading \& writing. "This enthusiasm is shown throughout all ages" (Pell \& Jarvis, 2001, p.852). Less desirable activities are those involving journaling and mathematics.

Reports on attitude and achievement indicate, "liking science was correlated with achievement in science" (Freedman, 1997, p.344). Past research presented conflicting 
hypotheses examined by Freedman: "attitude toward science has an impact on achievement in science knowledge rather than the reverse" (p.345). However, Freedman's study proved that "laboratory experience had a positive influence on the students' attitude toward science and their achievement in science knowledge" (p.352). More specifically stated as "attitude toward science influences achievement, with the additional idea that a hands-on laboratory program influences the attitude toward science of students and influences their achievement in science knowledge" (Freedman, 1997, p.353). Student response to "hands-on laboratory experience" in particular results in "high levels of involvement", "reduced level of discipline problems" and "general exuberance and enjoyment of science class" (Freedman, 1997, p.354). Attitudes change as children move from elementary to secondary education. "Younger pupils rate experiments in science more highly than do secondary pupils because... the curriculum is less assessment oriented at this stage and the pupils welcome the openended enquiries this allows" (Pell \& Jarvis, 2001, p.853). According to Pell and Jarvis, "It appears that the trend starts toward the end of primary years" (p.857). Early educational experiences form attitudes that "may influence children's attainment, consistency and quality of class work as well as their later views of science education and scientific occupations in secondary school and beyond" (Pell \& Jarvis, 2001, p.847). Gender differences within various age groups are noted as well: "Some girls temporarily lost self-confidence" (Jarvis \& Pell, 2002, p.996). "Researchers have observed that girls are more interested in science when it is presented in a social context" (Jarvis \& Pell, 2002, p.996). For example, attitude differences between genders were noted with elementary students participating in a science center experience (Jarvis \& Pell, 2002, 
p.988). Girls reported more interest and enthusiasm for science immediately following the experience; however, the increased enthusiasm was short-term. Enthusiasm fell back to initial pretest levels after 2 to 5 months. Contrary, boys indicated relatively constant levels of interest and enthusiasm regardless of the experience (Jarvis \& Pell, 2002, p. 989). Investigations support stereotypical gender bias with attitudes toward science: girls tend to "reject science" after elementary years (Pell \& Jarvis, 2001; Moore \& Foy, 1997). Boys' attitudes remain relatively steady; however, more recent studies regarding girls' attitudes with science are better than previously reported (Pell \& Jarvis, 2001, p.852). "The attitude pattern between the sexes only varies slightly as the pupils get older" (Pell \& Jarvis, 2001, p.852). "There is a clear trend, common to boys and girls, to rate science as less difficult and less demanding as they get older" (Pell \& Jarvis, 2001, p.857). General enthusiasm for science may be short term, but how an individual responds to science in social contexts is longer-lasting: social context scores for girls and boys immediately improved but didn’t fall back to pretest levels in subsequent tests (Jarvis \& Pell, 2002, p.991). As girls complete middle level education, their interest in science "declines more than boys" but may improve "with practical investigative activities linked more directly to a social context" (Pell \& Jarvis, 2001, p.858). "Those pupils who show the greater enthusiasm for school science tend to rate the worth of science for society more highly. Therefore the scale 'real world science' can provide a summary attitude measure of a general view of science" (Pell \& Jarvis, 2001, p.857).

Science attitudes are not fully understood: there is more research documenting achievement rather than attitude (George \& Kaplan, 1998; Pell \& Jarvis, 2002), which applies to students as well as parents. Research has shown that science attitudes are 
developed by influences from parents, teachers, and peers (Keeves, 1975). The results of this research project extend current practices because, although previous research supports improvements with inquiry-based instruction, it appears that more research is necessary. Studies dealing with inquiry and instruction are more effective and abundant in content areas such as biology and physics. (Chang \& Mao, 1998). "It is therefore essential and important to examine the effects of an inquiry-based instructional method on the achievement of students with an emphasis on the earth science subject." (Chang \& Mao, 1998). Science education should include opportunities and encouragement for "students to develop inquiry skills as early as possible" (Chang \& Mao, 1998). Furthermore, inquiry research is not as documented with middle school students compared to elementary or high school students. The results of this study advance research by including data for middle level students studying earth science concepts, neither of which has been documented in detail.

\section{Continuous Assessment}

Assessment is important to educational goals because it illustrates effectiveness of various tools and strategies utilized by educators. It is intended to demonstrate learning at all stages of the educational process in order to continuously improve the learning process. The assessment system is also connected to the content standards and benchmarks in an effort to provide the necessary information needed to improve learning for all students. Assessments include formal or informal measures of achievement that are instituted in many forms. With continuous assessment in the Mercedes Model for 
teaching and learning, teachers gauge each student's understanding, remedy misunderstandings, and re-teach when necessary to achieve deeper understanding. Discussions of investigations include errors, inconsistencies, and causes of problems. Through discussion students work through problem-solving skills and provide logical explanations for errors. Students also reflect on activities to help them get more out of the inquiry experience, which is metacognition. They become more aware of their thought processes throughout activities. They also keep a log of daily journal entries in order to evaluate individual progress while learning. Writing helps students retain knowledge while exhibiting how well the student mastered fundamental scientific understanding. Students respond in journals to open ended questions or quotes. For example, students write responses about how science is connected to other subjects they study, and then refer to their response after learning about content in each class. In this way, students are encouraged reflect how science concepts are connected to other classes and experiences.

Teachers have an important role in establishing proper environment to engage and encourage students to learn and to understand. Learning through inquiry is shown to be more effective for students than traditional instruction, where building a knowledge base occupies most instruction time. By instituting continuous assessment teachers ensure all students successful integrate knowledge and applications as outlined in educational goals. The end result is for students to become more engaged and therefore more interested in what they are learning when inquiry teaching methods are implemented. This makes science more enjoyable, interesting and applicable to student experiences; therefore, learning is more meaningful. 
To conclude, the nature of human inquiry centers on curiosity along with the ability to investigate and communicate what was learned during investigations, just as children discover the world by interacting with it. Inquiry in the science classroom can include a level of involvement and excitement that may not occur otherwise, particularly when the question investigated comes directly from the students. Allowing students to generate lists and then investigate, preferably with the scientific method or " $5 \mathrm{E}$ " learning process, strengthens problem-solving skills and builds confidence needed for more sophisticated investigations and understanding, particularly with full inquiry. Depending on educational goals, inquiry in education can be open or more structured. It can begin to explain unknown phenomena or be used to strengthen or prove hypotheses. This is true in science as well. Scientists participate in original studies to explain questions over their own observations or they set out to prove other hypotheses or theories. As students participate in their own inquiry activities they should be able to develop scientific knowledge and understand the work of other scientists. Consequently, through inquiry activities implemented in the classroom students become more scientifically literate. Students tend to learn main ideas as they are coached through learning processes. Rather than receiving information, students participating in inquiry activities discover for themselves how and why phenomena occur. Once students make observations, teachers incorporate the extra knowledge and understanding that students need as they become more sophisticated learners. Becoming scientifically literate entails using scientific ideas rather than simply knowing scientific information. 


\section{Chapter Three - Procedures}

Middle level students were involved in an investigation to determine if they could attain specific state and national standards concerning water quality using an inquiry-based instructional approach. The investigation consisted of a pretest, followed by an inquirybased water quality instructional unit, and a posttest.

\section{Instructors}

The water quality instructional unit was implemented in May 2006 with a total of 117 students in two Michigan locations: Houghton and Ortonville. Two participating middle level science teachers in the study were Mrs. Theresa Legg and myself. Although we taught at different schools, we shared educational philosophy and teaching style. As a general education teacher at Houghton-Portage Middle School, I implemented the water quality unit with a total of 106 students in four class periods. Mrs. Theresa Legg implemented the water quality unit with 16 special education students in a self-contained classroom at Brandon Middle School in Ortonville.

\section{Students}

The unit was implemented with 96 students in grade seven who had no previous water quality experience, and 21 students in a grade eight science class. For these grade eight students the water quality unit extended previous knowledge from an introductory water quality Michigan Environmental Education Curriculum Support (MEECS) unit taught during the previous school year. 
Students involved in this investigation were predominately Caucasian. Educational levels varied within the classes, yet overall ability levels were considered average or above average (based on comparison to the state average on standard M.E.A.P. test results). However, the Brandon Middle School special education students functioned below grade level, and received accommodations for the following special needs: learning disability (LD); attention deficit/hyperactivity disorder (ADHD); cognitive impairment (CI); emotional impairment (EI); otherwise health impaired (OHI).

\section{Facilities}

All classes followed the same schedule of daily 50-minute class periods over a two-week period of time. This research primarily occurred in Houghton Middle School's grade seven science classes. General education classes included 21-28 students in each class. Students in all classes were arranged in small work groups (of 3-4 students), which accommodated discussions for understanding.

\section{Procedures}

Prior to instruction students were informed about participating in a teacher's research project that followed the scientific method as practiced in middle school science classes (Table 1). Student identification numbers were used for all responses, for confidentiality. The pretest administered at the beginning of the unit also served as the posttest (Appendix A). The instructional unit was implemented (Table 2) in five classes. 


\section{Table 1. Order of Procedures}

Step Procedures

1 Students involved in this study were given a confidential identification number.

2 Students were informed about the water quality educational research.

3 Pre-assessments (test and attitude survey) were administered.

4 Inquiry-based instruction (Appendix A) occurred over 2-3 weeks of class time.

5 Data was collected: student class work and teacher journal.

Class work was continuously monitored understanding.

6 Dollar Bay data was analyzed: temperature and dissolved oxygen were plotted

7 Post-assessments (test and attitude survey) were administered.

8 Data was analyzed: Test and survey results were graphically represented.

9 Alternative assessment was administered to re-teach: Video "After the Storm" was shown and a "Top 10" list of water quality concerns was generated.

Table 2: Instruction for Water Quality Unit, May 2006

\begin{tabular}{llllll}
\hline & Monday & Tuesday & Wednesday & Thursday & Friday \\
\hline $\begin{array}{l}\text { Week } \\
\text { One }\end{array}$ & $\begin{array}{l}\text { Pretest \& } \\
\text { Survey }\end{array}$ & $\begin{array}{l}\text { Module: } \\
\text { Temperature }\end{array}$ & Module: DO & $\begin{array}{l}\text { Graph T \& } \\
\text { DO (from } \\
\text { modules) }\end{array}$ & $\begin{array}{l}\text { Module: } \\
\text { Nitrate \& } \\
\text { Phosphate }\end{array}$ \\
$\begin{array}{lllll}\text { Week } \\
\text { Two }\end{array}$ & $\begin{array}{l}\text { LAB: Stream } \\
\text { Table, Terms }\end{array}$ & $\begin{array}{l}\text { LAB: Stream } \\
\text { Table, tests }\end{array}$ & $\begin{array}{l}\text { LAB: Stream, } \\
\text { discussion }\end{array}$ & Review Game & $\begin{array}{l}\text { Posttest \& } \\
\text { Survey }\end{array}$ \\
$\begin{array}{l}\text { Week } \\
\text { Three }\end{array}$ & $\begin{array}{l}\text { Classes were } \\
\text { not in }\end{array}$ & $\begin{array}{l}\text { Video “After } \\
\text { the Storm” \& } \\
\text { 'Top 10' List }\end{array}$ & $\begin{array}{l}\text { Dollar Bay } \\
\text { Data (8th } \\
\text { grade) }\end{array}$ & $\begin{array}{l}\text { Dollar Bay } \\
\text { Data (8th } \\
\text { grade) }\end{array}$ & $\begin{array}{l}\text { Classes } \\
\text { were not in } \\
\text { session }\end{array}$ \\
\hline
\end{tabular}




\section{Instruction}

Instruction of the water quality unit occurred in approximately 3 weeks (Table 2).

Inquiry-based instruction used website modules for guided inquiry on temperature, dissolved oxygen, nitrates and phosphates (PEER Curriculum, 2001). Data from Dollar Bay connected the water quality concepts to a real-world example (Appendix C). The following water quality concepts were covered during instruction:

Physical and chemical variables impact water quality;

Organisms, fertilizers and pollutants affect the levels of dissolved oxygen;

Water is most dense at $4^{\circ} \mathrm{C}$;

Water mixes when temperature is constant; and

Water stratifies when temperature differences create layers.

Instruction incorporated the " $5 E$ " Learning Cycle: Engage, Explore, Explain, Elaborate and Evaluate (Appendix A). Effectiveness of the " $5 E$ " Learning Cycle was measured by Michigan Department of Education (MDE) standards: identify, describe, explain, and evaluate (Table 3). The general scientific benchmarks "constructing and reflecting on scientific knowledge" refer to necessary skills and processes used during investigations. The MDE Benchmarks are referenced by numbers and letters:

"The first numeral in the code is a Roman numeral; it identifies the content area strand. The second numeral is an Arabic numeral; it identifies the content standard... The third numeral is another Arabic numeral; it identifies a benchmark." (MDE, 1996, p.14). 
Categories used in the water quality unit include: Constructing New Scientific

Knowledge (C), Reflecting on Scientific Knowledge (R), Hydrosphere (EH), Ecosystems

(LEC), Organization of Living Things (LO), Matter and Energy (PME).

Table 3. MDE Benchmarks Addressed in the Water Quality Curriculum

\begin{tabular}{lll}
\hline Standard & Page & Benchmark \\
\hline C-I.1.5 & p.4 & Use sources of information in support of scientific investigations. \\
R-II.1.1 & p.5 & Evaluate the strengths and weaknesses of claims, arguments, or data. \\
C-II.1.5 & p.6 & Develop an awareness of and sensitivity to the natural world. \\
R-II.1.5 & p.6 & Develop an awareness and sensitivity to the natural world. \\
LO-III.2.3 & p.10 & Describe evidence that plants make and store food. \\
LO-III.2.4 & p.11 & Explain how selected systems and processes work together in animals. \\
LEC-III.5.1 & p.15 & Describe common patterns of relationships among populations. \\
LEC-III.5.2 & p.15 & Describe how organisms acquire energy from sunlight. \\
LEC-III.5.5 & p.17 & (HS) Describe how carbon and soil nutrients cycle through ecosystems. \\
LEC-III.5.6 & p.18 & Describe ways in which humans alter the environment. \\
PME-IV.1.2 & p.19 & $\begin{array}{l}\text { Explain when length, mass, weight, density, area, volume or } \\
\text { temperature are appropriate descriptors of properties. }\end{array}$ \\
EH-V.2.2 & p.37 & Describe how surface water in Michigan reaches the ocean and returns. \\
EH-V.2.4 & p.38 & Describe the origins of pollution in the hydrosphere. \\
EH-V.2.1 & p.37 & (HS) Identify \& describe regional watersheds. \\
EH-V.2.2 & p.38 & (HS) Describe how human activities affect water quality in the \\
& hydrosphere. & \\
\hline & &
\end{tabular}


From these general benchmarks (Table 3) students investigated more specific details, similar to Wiske's "generative topics". Students graphed and analyzed data from the Temperature and Dissolved Oxygen website modules (C-I.1.4). Students correlated dissolved oxygen (DO) levels and analyzed the significance of DO levels (C-I.1.5). Next the graphs were analyzed, which resulted in reflecting on scientific knowledge with realworld examples using dissolved oxygen levels to determine survival of certain 'classes' of organisms based on pollution-tolerance (R-II.1.1 and R-II.1.5).

Understanding was expanded through discussions of dissolved oxygen levels and potential affects of DO levels on organism survival. Students understood DO and then applied that knowledge to various conditions that affect oxygen levels (R-II.1.1). Conditions necessary for organism survival were connected with classes of organisms based on oxygen, temperature, or pollution sensitivity. Then the stream table lab exercise connected pollution affects and human affects such as land development. Because different lab groups created different streams, students saw how certain scenarios allowed pollution contamination downstream of the source (EH-V.2.4). This promoted comparisons and subsequent discussion of why certain areas were less acceptable for land development. Developing "perspective and empathy" (Wiggins) continued with viewing a video (MEECS) regarding effects of pollution on organisms and how individuals can help minimize effects of pollution (LEC-III.5.6).

Instruction connected specific benchmarks and scientific concepts with an ecological theme: "Looking at the relationships between populations" (LEC-III.5.1), "effects of humans on organisms and ecosystems" (LEC-III.5.6). Even more specifically, focusing on the water unit provided students with local examples of concepts fostering personal 
connections with the content (Strand V), which reinforced development of awareness and sensitivity to the natural world (R-II.1.5). Students addressed concepts in the Earth Science content area, analyzed the data based on the general concepts learned, and concluded what the data meant with respect to their understanding.

General education students were responsible for journaling individual responses that promoted activity-based learning, discussion, and individual contribution. Special education students received accommodations for reading comprehension and writing, which resulted in less written work from students and more in-class discussion.

\section{Assessment}

Student progress and achievement of the research question were measured with formal quantitative assessments and informal qualitative assessments. An achievement test quantitatively determined if and where students made progress. Other types of assessments were also used to reflect effectiveness of inquiry-based instruction: using more than one assessment triangulated data more conclusively (Mills, 2003, p.52). Assessments were administered on the first day of water-quality instruction. The start date varied for each class, but all classes started on a Monday in May 2006, which was Marking Period 4 on the academic calendar. Absent students completed the preassessments on the day of their return. Both participating teachers scored the assessments after they completed the instructional unit. Assessment results provided data that included 1) Each student's overall score and the class average for assessments, 2) Student score on each item and the class average on assessment items, and 3) Calculations for gain and effect size on assessments for each class. 
Data was entered by class period on an Excel worksheet where it was analyzed (Appendix B). Assessments (tests and surveys) were analyzed to determine whether the instructional objectives were met and why certain objectives were missed.

\section{Knowledge Assessments}

Knowledge assessments included a pretest and posttest, which quantitatively evaluated knowledge and understanding of concepts. The assessment consisted of 25 questions that were developed to connect the Mercedes Model, Wiske's Model, and Michigan Department of Education's Benchmarks (Chapter 2). Items assessed knowledge (K), understanding (U), and application (A) of knowledge described in the Mercedes Model. Each test item also measured students' ability to "describe, predict, explain, elaborate, and evaluate" (MDE Benchmarks). The assessment also connected Wiske's Model of instruction (Table 4) through generative topics (G), understanding goals and performances $(\mathrm{U})$, and ongoing assessment $(\mathrm{OA})$. Accommodations for students in the special education class were orally administering the test and rewriting the items to have only three options to choose from rather than five, which helped these students to process information.

\section{Attitude Assessments}

Attitude assessments, presurveys and postsurveys, quantitatively and qualitatively reflected student attitudes. Surveys included a spectrum of opinions along with openended responses (Appendix A). Surveys rated student understanding quantitatively through the Likert scale. This scale included five levels of 'agreement' that were given a numerical value (Mills, 2003, p.65). With the Likert scale, strongly disagree was noted most negative (-2) whereas strongly agree was noted most positive (2). Survey score 
results indicated a continuum of positive or negative attitudes. Special education students received accommodations to help process information: the survey was read aloud and it had only three options to choose from rather than five options.

\section{Continuous Assessment}

Graded lab-class work evaluated continuous progress of conceptual understanding with opportunity to re-do the work until it was completed correctly. A journal of teacher impressions of lessons and student responses provided other qualitative monitoring. The variety of assessments triangulated data in order to verify observations and results.

\section{Analysis}

The change in percentage in assessment items was used as the average gain in knowledge and attitude. The following example shows the all student / all item composite average gain in knowledge (Table 6).

$$
\begin{aligned}
& \text { AverageGain }=\bar{X}_{\text {classposttest }}-\bar{X}_{\text {classpretest }} \\
& \text { AverageGain }=58.1 \%-38.1 \% \\
& \text { AverageGain }=18.6 \%
\end{aligned}
$$

Effect size (Bracey, 2000) was used to determine if learning occurred and whether taught objectives were met. Effect size was calculated with the Bracey/Shaver formula (Bracey, 2000, Shaver, 1985): the difference in mean scores (control - experimental) was divided by the standard deviation of the pretest. For the following calculation, the experimental group was the class (posttest) after water-quality instruction and the control group was the class (pretest) before instruction. Effect Size was averaged to create a composite for all classes. 
The following example shows an all student / all item composite for effect size (Table 6).

$$
\begin{aligned}
& \text { Effect Size }=\frac{\overline{\mathrm{X}}_{\text {class postest }}-\overline{\mathrm{X}}_{\text {class pretest }}}{\mathrm{SD}_{\text {class pretest }}} \\
& \text { Effect Size }=\frac{58.1-38.1}{.44}
\end{aligned}
$$

$$
\text { Effect Size }=.50
$$

The effect size normalized data for comparison between classes (Table 8) because it uses standard deviations to note improvements in the assessments. I considered a pretest/posttest change resulting in an effect size greater than 0.3 to be practically important (Bracey, 2000) for this study, and therefore large enough to declare that instructional objectives had been met.

Gains and effect size was calculated for test items \#1 through \#18 because they were not open-ended responses. Despite difficulty in quantifying gains in knowledge on items \#19 through \#25, they were connected to instructional models and MDE Standards (Table 4). Informal qualitative assessment of responses on the posttest included specific details than on the pretest, even on items that students answered correctly. For example, when devising a plan to protect Michigan's water resources students correctly included general and logical statements on the pretest, but included specific examples learned about dissolved oxygen from the modules or laboratory activities. 
Table 4. Correlate Assessment, Educational Models, and MI Benchmarks

\begin{tabular}{|c|c|c|c|c|}
\hline $\begin{array}{l}\text { Test } \\
\text { Item }\end{array}$ & $\begin{array}{l}\text { Michigan Department of Education } \\
\text { (MDE) Standards \& Benchmarks }\end{array}$ & $\begin{array}{l}\text { MDE } \\
\text { Benchmark }\end{array}$ & $\begin{array}{l}\text { Mercedes } \\
\text { Model }\end{array}$ & $\begin{array}{l}\text { Wiske's } \\
\text { Model }\end{array}$ \\
\hline 1 & LEC-III.5.1, p.15 & Describe & $\mathrm{K}$ & G \\
\hline 2 & C-II.1.5 p.6 & Develop & $\mathrm{K}, \mathrm{U}$ & G \\
\hline 3 & EH-V.2.4 p.38 & Describe & K & $\mathrm{U}$ \\
\hline \multirow[t]{2}{*}{4} & EH-V.2.2, p.37; LEC-III.5.6, p.18 & Describe & K & $\mathrm{U}$ \\
\hline & EH-V.2.1 $1_{(\mathrm{HS})}, \mathrm{p} .37$ & Identify & & \\
\hline 5 & EH-V.2.2 $2_{(\mathrm{HS})}$, p.38; LEC-III.5.6, p.18 & Describe & $\mathrm{K}$ & G \\
\hline 6,7 & PME-IV.1.2, p.19 & Explain & $\mathrm{K}$ & $\mathrm{G}, \mathrm{U}$ \\
\hline 8,9 & No benchmark & N/A & $\mathrm{K}$ & $\mathrm{U}$ \\
\hline 10 & EH-V.2.2, p.37 & Describe & $\mathrm{K}$ & $\mathrm{U}$ \\
\hline 11 & LEC-III.5.1, p.15; LEC-III.5.5(HS), p.17 & Describe & K & $\mathrm{U}$ \\
\hline 12 & LEC-III.2.4, p.11 & Explain & $\mathrm{U}$ & G \\
\hline 13 & LO-III.2.3, p.10; LEC-III.5.2, p.15 & Describe & $\mathrm{U}$ & G \\
\hline \multirow[t]{2}{*}{14} & C-I.1.5, p.4 & Use Sources & U & U \\
\hline & R-II.1.5, p.6 & Develop & & \\
\hline 15,16 & R-II.1.5, p.6 & Develop & U & $\mathrm{U}, \mathrm{OA}$ \\
\hline 17 & LEC-III.5.2, p.15; LEC-III.5.5.(HS), p.17 & Describe & $\mathrm{U}$ & $\mathrm{U}-\mathrm{OA}$ \\
\hline 18,19 & LEC-III.5.5 $(\mathrm{HS})$, p. 17 & Describe & $\mathrm{K}, \mathrm{U}$ & U \\
\hline 20,21 & C-II.1.5, p.6 & Develop & $\mathrm{U}, \mathrm{A}$ & $\mathrm{U}$ \\
\hline $22-23$ & C-I.1.5, p.4 & Use Sources & $\mathrm{U}, \mathrm{A}$ & $\mathrm{OA}$ \\
\hline $24-25$ & EH-V.2.4, p.38; EH-V.2.1 $1_{(\mathrm{HS})}$, p.37 & Describe & $\mathrm{U}, \mathrm{A}$ & OA \\
\hline
\end{tabular}


(This page is deliberately blank) 


\section{Chapter Four - Results}

Data included 1) Individual student assessment score and class average assessment score;

2) Individual student score for each item and class averages on assessment items; and 3)

Calculations for gain and effect size on assessments for each class period. Data analysis

determined that the curriculum objectives were met, and middle level students learned

through inquiry-based instruction for a "water quality" unit. Instruction encouraged

analytical and critical thinking skills rather than recollection of factual knowledge.

Student knowledge of water quality concepts improved after inquiry-based instruction, where the teacher facilitated rather than provided knowledge. The data showed increases in student knowledge, but not necessarily in all students' ability to apply knowledge.

Also, inquiry-based instruction was engaging for students, yet activities did not have a conceptual focus that occurs with traditional instruction. In a sense, students were involved and learned the nature of science but they did not necessarily understand science content through activity alone (Rudolf, 2005).

Attitude survey scores did not reflect 'better' attitudes following the unit. Some students reported they became frustrated and less motivated when they didn't understand. Student comments from the attitude survey also included 'explain more' and 'more hands-on activities' in class. True to inquiry-based activities, they were not given answers but were encouraged to discover answers. Particularly for students who have difficulty with reading comprehension, finding answers caused anxiety and confusion or they simply copied answers from another student. 


\section{Knowledge: Pretest and Posttest}

The curriculum and instruction helped the students attain objectives of the teaching unit. As expected, gains in knowledge occurred in each science class; however, the magnitude varied depending on the class (Table 5). The notable trend was similar gains occurred across individual classes; likewise, the same items were missed by individual classes.

Despite the unexpected negative change from pretest to posttest, this 'loss' was consistent among all of the class periods and occurred on items that were not covered thoroughly during instruction.

Table 5. Pretest/Posttest Gains and Effect Size by Class Period

\begin{tabular}{lccccc}
\hline & \multicolumn{5}{c}{ Class Period } \\
\cline { 2 - 6 } Pre/Post Knowledge Comparison & 1 & 3 & 4 & 5 & S.E. \\
\hline Number of Students (N) & 21 & 27 & 26 & 27 & 16 \\
Average Pre/Post Gain (\%) & $15.9 \%$ & $20.2 \%$ & $21.4 \%$ & $21.6 \%$ & $10.1 \%$ \\
Pretest Standard Deviation & 0.41 & 0.43 & 0.42 & 0.35 & 0.46 \\
Effect Size & 0.41 & 0.56 & 0.53 & 0.56 & 0.26 \\
\hline
\end{tabular}

Individual Classes. Period 1 (Science 8 ) average test scores increased by $15.9 \%$, from $41.8 \%$ on the pretest to $57.7 \%$ on the posttest. Negative gains in knowledge occurred on items \#2 (from 18 correct responses on pretest to 16 on posttest), \#7 (from 15 to 13 correct responses), and \#10 (from 11 correct responses on pretest to 8 on posttest). 
Period 3 (Science 7) gained $20.2 \%$ from $39.7 \%$ on the pretest to $59.9 \%$ on the posttest. Negative gains occurred on items \#2 (from 18 to 15 correct responses), \#8 (from 21 to 20 correct responses), and \#12 (from 22 to 20 correct responses).

Period 4 (Science 7) achieved $21.4 \%$ gain from $39.3 \%$ on the pretest to $60.9 \%$ on the posttest. Negative gains occurred on items \#2 (from 22 to 20 correct responses), \#12 (from 22 to 21 correct responses), and \#15 (from 7 to 6 correct responses). Period 5 (Science 7) achieved $21.6 \%$ gain from $34 \%$ on the pretest to $56.6 \%$ on the posttest. There was no change on items \#8 (with 21 correct responses) and \#12 (with 24 correct responses). A negative gain in knowledge occurred on item \#1 (from 1 correct responses on pretest to 0 on posttest).

Period S.E. (Science 7) increased $10.1 \%$ from $45.8 \%$ on the pretest to $55.9 \%$ on the posttest (Appendix B). Negative gains occurred on items \#2 (from 11 to 10 correct responses), \#8 (from 11 to 2 correct responses), and \#15 (from 11 to 8 correct responses). Composite Results. Overall test scores improved by $18.6 \%$, which indicated all classes gained knowledge. The average standard deviation decreased from the pretest $(0.44)$ to the posttest (0.46), which indicated less spread of correct answers on the final assessment. The average effect size (0.5) for all the test items, across all the students, was greater than my predetermined value for practical importance of these results. This indicated practical importance in overall test scores because values above 0.3 were determined significant (Table 6). 


\section{Objective Attainment: Class Averages of Assessment Scores}

Each item on the test was assigned to at least one specific instructional objective to show how instruction affected knowledge. Gains on more difficult test items indicated students were able to apply knowledge. Class periods vary in knowledge gains, yet these gains correlated to objectives and assessment items (Table 7). Effect size was averaged for all classes, which determined whether objectives were met. Objectives were 'met' when effect size was greater than 0.3: these show practical importance (Table 8). 
Table 6. All Student Pre/Post Knowledge Gain and Effect Size by Item

\begin{tabular}{|c|c|c|c|c|c|c|c|c|c|}
\hline \multirow[b]{2}{*}{ Item } & \multirow[b]{2}{*}{$\mathrm{N}$} & \multicolumn{3}{|c|}{ Pretest } & \multicolumn{3}{|c|}{ Posttest } & \multirow[b]{2}{*}{ Gain } & \multirow[b]{2}{*}{ ES* } \\
\hline & & \#Correct & $\bar{X}(\%)$ & $\mathrm{SD}$ & \#Correct & $\bar{X}(\%)$ & SD & & \\
\hline 1 & 117 & 17 & $14.5 \%$ & 0.35 & 30 & $25.6 \%$ & 0.44 & $11.1 \%$ & 0.5 \\
\hline 2 & 117 & 90 & $76.9 \%$ & 0.42 & 83 & $70.9 \%$ & 0.45 & $-6.0 \%$ & -0.2 \\
\hline 3 & 117 & 22 & $18.8 \%$ & 0.39 & 36 & $30.8 \%$ & 0.46 & $12.0 \%$ & 0.4 \\
\hline 4 & 117 & 49 & $41.8 \%$ & 0.49 & 75 & $64.1 \%$ & 0.48 & $22.2 \%$ & 0.6 \\
\hline 5 & 117 & 61 & $52.1 \%$ & 0.50 & 74 & $63.3 \%$ & 0.48 & $11.1 \%$ & 0.3 \\
\hline 6 & 117 & 33 & $28.2 \%$ & 0.45 & 80 & $68.4 \%$ & 0.47 & $40.2 \%$ & 0.9 \\
\hline 7 & 117 & 30 & $25.6 \%$ & 0.44 & 73 & $62.4 \%$ & 0.48 & $36.8 \%$ & 1.3 \\
\hline 8 & 117 & 90 & $76.9 \%$ & 0.42 & 85 & $72.7 \%$ & 0.45 & $-4.3 \%$ & -0.1 \\
\hline 9 & 117 & 33 & $28.2 \%$ & 0.45 & 37 & $31.6 \%$ & 0.47 & $3.4 \%$ & 0.1 \\
\hline 10 & 117 & 51 & $43.6 \%$ & 0.50 & 72 & $61.5 \%$ & 0.49 & $17.9 \%$ & 0.3 \\
\hline 11 & 117 & 42 & $35.3 \%$ & 0.48 & 90 & $76.9 \%$ & 0.42 & $41.0 \%$ & 0.8 \\
\hline 12 & 117 & 90 & $75.6 \%$ & 0.42 & 94 & $80.3 \%$ & 0.40 & $3.4 \%$ & 0.1 \\
\hline 13 & 117 & 69 & $58.0 \%$ & 0.49 & 89 & $76.9 \%$ & 0.43 & $17.1 \%$ & 0.3 \\
\hline 14 & 117 & 20 & $16.8 \%$ & 0.38 & 67 & $57.3 \%$ & 0.49 & $40.2 \%$ & 1.1 \\
\hline 15 & 117 & 22 & $18.5 \%$ & 0.39 & 28 & $23.9 \%$ & 0.43 & $5.1 \%$ & 0.2 \\
\hline 16 & 117 & 36 & $30.3 \%$ & 0.46 & 63 & $53.9 \%$ & 0.50 & $23.1 \%$ & 0.5 \\
\hline 17 & 117 & 37 & $31.1 \%$ & 0.47 & 79 & $67.5 \%$ & 0.47 & $35.9 \%$ & 0.8 \\
\hline 18 & 117 & 40 & $33.6 \%$ & 0.47 & 69 & $58.9 \%$ & 0.49 & $24.8 \%$ & 0.6 \\
\hline \multicolumn{2}{|c|}{ Average } & 45.3 & $38.1 \%$ & 0.44 & 67 & $58.1 \%$ & 0.46 & $18.6 \%$ & 0.5 \\
\hline
\end{tabular}


Table 7. Average Gain in Pre/Post Knowledge by Item and Class Period

\begin{tabular}{|c|c|c|c|c|c|c|}
\hline \multirow[b]{2}{*}{ Item \# } & \multicolumn{5}{|c|}{ Class Hour } & \multirow[b]{2}{*}{ Average } \\
\hline & 1 & 3 & 4 & 5 & S.E. & \\
\hline 1 & $0.0 \%$ & $7.4 \%$ & $26.9 \%$ & $-3.7 \%$ & $31.3 \%$ & $12.4 \%$ \\
\hline 2 & $-9.5 \%$ & $-11.1 \%$ & $-7.7 \%$ & $3.7 \%$ & $-6.3 \%$ & $-6.2 \%$ \\
\hline 3 & $14.3 \%$ & $0.0 \%$ & $23.1 \%$ & $7.4 \%$ & $18.8 \%$ & $12.7 \%$ \\
\hline 4 & $9.5 \%$ & $22.2 \%$ & $23.1 \%$ & $11.1 \%$ & $56.3 \%$ & $24.4 \%$ \\
\hline 5 & $28.6 \%$ & $7.4 \%$ & $3.8 \%$ & $3.7 \%$ & $18.8 \%$ & $12.5 \%$ \\
\hline 6 & $47.6 \%$ & $48.1 \%$ & $42.3 \%$ & $40.7 \%$ & $12.5 \%$ & $38.2 \%$ \\
\hline 7 & $-9.5 \%$ & $55.6 \%$ & $53.8 \%$ & $51.9 \%$ & $12.5 \%$ & $32.9 \%$ \\
\hline 8 & $9.5 \%$ & $-3.7 \%$ & $11.5 \%$ & $0.0 \%$ & $-56.3 \%$ & $-7.8 \%$ \\
\hline 9 & $0.0 \%$ & $3.7 \%$ & $0.0 \%$ & $7.4 \%$ & $6.3 \%$ & $3.5 \%$ \\
\hline 10 & $-14.3 \%$ & $25.9 \%$ & $34.6 \%$ & $37.0 \%$ & $-12.5 \%$ & $14.1 \%$ \\
\hline 11 & $47.6 \%$ & $48.1 \%$ & $42.3 \%$ & $51.9 \%$ & $0.0 \%$ & $37.9 \%$ \\
\hline 12 & $9.5 \%$ & $-7.4 \%$ & $-3.8 \%$ & $0.0 \%$ & $31.3 \%$ & $5.9 \%$ \\
\hline 13 & $14.3 \%$ & $14.8 \%$ & $46.2 \%$ & $7.4 \%$ & $-6.3 \%$ & $15.34 \%$ \\
\hline 14 & $38.1 \%$ & $48.1 \%$ & $34.6 \%$ & $44.4 \%$ & $31.3 \%$ & $39.3 \%$ \\
\hline 15 & $14.3 \%$ & $14.8 \%$ & $-3.8 \%$ & $11.1 \%$ & $-18.8 \%$ & $3.5 \%$ \\
\hline 16 & $19.0 \%$ & $33.3 \%$ & $15.4 \%$ & $14.8 \%$ & $37.5 \%$ & $24.0 \%$ \\
\hline 17 & $61.9 \%$ & $29.6 \%$ & $26.9 \%$ & $40.7 \%$ & $18.8 \%$ & $35.6 \%$ \\
\hline 18 & $4.8 \%$ & $25.9 \%$ & $15.4 \%$ & $59.3 \%$ & $6.3 \%$ & $22.3 \%$ \\
\hline
\end{tabular}


Table 8. Objective Attained as a Result of Instruction

\begin{tabular}{|c|c|c|c|c|c|}
\hline $\begin{array}{c}\text { MDE } \\
\text { Objective }\end{array}$ & $\begin{array}{c}\text { MDE } \\
\text { page \# }\end{array}$ & Benchmark & Question\# & $\begin{array}{l}\text { Composite } \\
\text { Effect Size }\end{array}$ & $\begin{array}{c}\text { MDE Met } \\
\mathrm{ES}>0.3\end{array}$ \\
\hline Describe & p. 10 & LO-III.2.3 & 13 & 0.3 & Met \\
\hline Describe & p.15 & LEC-III.5.1 & 1,11 & $0.5 / 0.8$ & Met \\
\hline Describe & p. 15 & LEC-III.5.2 & 13,17 & $0.3 / 0.8$ & Met \\
\hline Describe & p. 17 & LEC-III.5.5 (HS) & $11,17,18$ & $0.8 / 0.8 / 0.6$ & Met \\
\hline Describe & p. 18 & LEC-III.5.6 & 4,5 & $0.6 / 0.3$ & Met \\
\hline Identify & p.37 & EH-V.2.1 (HS) & 4 & 0.6 & Met \\
\hline Describe & p.37-38 & EH-V.2.2 (HS) & $4,5,10$ & $0.6 / 0.3 / 0.3$ & Met \\
\hline Describe & p.38 & EH-V.2.4 & 3 & 0.4 & Met \\
\hline Develop & p.6 & C-I.1.5 & 2,14 & $-0.2 / 1.1$ & Met \\
\hline \multirow[t]{2}{*}{ Develop } & p.6 & R-II.1.5 & 14 & 1.1 & Met \\
\hline & & & $15 \& 16$ & $0.2 / 0.5$ & \\
\hline Explain & p.11 & LO-III.2.4 & 12 & 0.1 & Not met \\
\hline Explain & p.19 & PME-IV.1.2 & 6,7 & $0.9 / 1.3$ & Met \\
\hline
\end{tabular}




\section{Attitude Survey: Presurvey and Postsurvey}

The curriculum and instruction resulted in learning but didn't significantly improve attitude. The magnitude of change in attitude varied by class hour; yet statistically, survey results indicated no substantial change in attitude (Table 9).

Table 9. Pre/Post Attitude Gains and Effect Size by Class Period

\begin{tabular}{lccccc}
\hline & \multicolumn{5}{c}{ Class Period } \\
\cline { 2 - 6 } & 1 & 3 & 4 & 5 & S.E. \\
\hline Number of Students (N) & 21 & 27 & 26 & 27 & 16 \\
Average Pre/Post Gain (\%) & -1.7 & -0.3 & 8.2 & -0.3 & -4.6 \\
Presurvey Standard Deviation (SD) & 11.5 & 8.8 & 7.5 & 7.4 & 10.0 \\
Effect Size (ES) & -0.15 & -0.03 & 1.09 & -0.04 & -0.46 \\
\hline
\end{tabular}

Individual Classes. Period 1 (Science 8) overall attitude scores declined (-1.7\%) after instruction. Students indicated they "enjoy science" (5 presurvey to 9 postsurvey) and "learning best by listening" (5 presurvey to 11 postsurvey). Both surveys indicated strong agreement that "Learning is best when I'm active" (9 presurvey to 11 postsurvey). Period 3 (Science 7) showed overall decrease (-0.3\%) in attitude. However, students do "Enjoy science" (6 presurvey to 9 postsurvey) and "Like self-discovery" (10 presurvey to 14 postsurvey). This section had more girls than boys: they all were responsive, selfmotivated, cooperative workers.

Period 4 (Science 7) overall attitudes improved (8.2\%). Students reported "Science is important" (17 presurvey to 21 postsurvey); "Like discovery" (14 to 17 postsurvey); "Learn best by reading" (11 to 17 postsurvey); "Like questioning" (13 to 16 postsurvey); 
"Career in science" (10 to 13 postsurvey); "Good at science" (16 to 20 postsurvey);

"Science applies to life" (16 to 21 postsurvey). This section was mostly grade seven boys who were polarized by attitude, motivation and participation.

Period 5 (Science 7) attitudes decreased (-0.3\%) after instruction. However, students reported being "Good at science" (17 presurvey to 20 postsurvey). Girls outnumbered boys in this period. Although polarized by ability, strong students outnumbered students who struggled with reading comprehension. Also, this section had behavior problems such as inattentiveness, refusal to work, and incompletion of work.

Period S.E (Science 7) attitudes declined (-4.6\%). This section received accommodations during instruction, yet attitudes decreased 19\% for "Science is easy" and "Science is important" (5 on presurvey to 3 postsurvey). Attitudes decreased 13\% for "Enjoy science", "Science applies", and "Learn by listening" (3 fewer students on postsurvey). With various difficulties, these students were unsuccessful when mainstreamed in general education classes. Along with low attitudes about education, students were severely limited in their reading comprehension.

Composite Results. No significant change was observed in average overall attitudes for all classes (Table 9). Students reported on the postsurvey that they "Learn best by reading" (Item \#8) and are "Good at science" (Item \#14). However, fewer students reported on the postsurvey that "Science is important" (Item \#2), and "Science is difficult" (Item \#4). Students also reported they "Like discovery" (Item \#6).

Interestingly, students responded on the postsurvey's open-ended item that teachers help me learn better by "explaining more" despite enjoyment of independent discovery. 
Table 10. Average Gain and Effect Size for Pre/Post Attitude by Item and Class Period

\begin{tabular}{|c|c|c|c|c|c|c|c|c|c|}
\hline \multirow[b]{2}{*}{ Item } & \multirow[b]{2}{*}{ Type* } & \multicolumn{5}{|c|}{ Change in Attitude by Class period } & \multirow[b]{2}{*}{$\begin{array}{c}\text { Average } \\
\text { Gain }\end{array}$} & \multirow[b]{2}{*}{ SD } & \multirow[b]{2}{*}{$\begin{array}{l}\text { Effect } \\
\text { Size** }\end{array}$} \\
\hline & & 1 & 3 & 4 & 5 & $\mathrm{SE}$ & & & \\
\hline 1 & A & -5 & 4 & 7 & 0 & 13 & 3.8 & 6.1 & 0.6 \\
\hline 2 & A & -14 & -4 & 15 & -11 & -19 & -6.6 & 11.8 & -0.6 \\
\hline 3 & A & -14 & 12 & -7 & 7 & 6 & 0.8 & 9.7 & 0.1 \\
\hline 4 & A & 0 & -19 & 4 & 4 & -19 & -6.0 & 10.7 & -0.6 \\
\hline 5 & A & -5 & 4 & 7 & 11 & -6 & 2.2 & 6.7 & 0.3 \\
\hline 6 & I & 0 & 15 & 11 & -11 & -6 & 1.8 & 9.9 & 0.2 \\
\hline 7 & I & 29 & 8 & -7 & -4 & -13 & 2.6 & 14.9 & 0.2 \\
\hline 8 & I & 0 & -4 & 19 & 11 & 0 & 5.2 & 8.5 & 0.6 \\
\hline 9 & I & -10 & -8 & 7 & -7 & -6 & 4.8 & 6.0 & -0.8 \\
\hline 10 & A & 5 & 4 & 4 & -7 & 13 & 3.8 & 6.4 & 0.6 \\
\hline 11 & A & 19 & 0 & 7 & 0 & -13 & 2.6 & 10.4 & 0.2 \\
\hline 12 & I & -5 & -12 & 11 & -4 & -6 & -3.2 & 7.6 & -0.4 \\
\hline 13 & A & -10 & 4 & 11 & 0 & 6 & 2.2 & 7.1 & 0.3 \\
\hline 14 & A & -5 & 0 & 15 & 11 & -6 & 3.0 & 8.5 & 0.4 \\
\hline 15 & B & -10 & -8 & 19 & -4 & -13 & -3.2 & 11.5 & -0.3 \\
\hline \multicolumn{2}{|c|}{ Averages } & -2 & 0 & 8 & 0 & -5 & 0.28 & 9.06 & 0.06 \\
\hline
\end{tabular}




\section{Observations}

Generally, students in each section seemed interested in participating as test subjects and cooperated even though their test scores weren't calculated in final grades.

Class work. Inquiry instruction with the computer modules seemed to generate positive attitudes; however, data indicated this was mostly true for high performing students. Students helped one another complete the modules and asked the teacher for assistance when needed. When discussing and solving application questions from the guided inquiry worksheets, students referred to the modules. For example, one student told another, "You can't just do the worksheet, you really have to read the section first!" Evaluations of class work determined whether students correctly understood concepts. The computer modules were completed in 2-3 class periods; so key concepts from the previous day were reviewed prior to moving on to the next section. Students who missed that information returned to the previous module with teacher assistance before they moved onto the next module. For example, students with incomplete module worksheets received guidance through the section so as to "re-teach" the missed concept. This approach was also applied when the teacher "roved" to "spot-check" student work. Students also had "redo" opportunities assigned for homework when class work was incorrect. For example, students created temperature versus dissolved oxygen graphs (Appendix A) for later analysis where levels of dissolved oxygen connected to survival of organisms. Another example for application of knowledge included effects of dissolved oxygen in a lake: students applied the graphs to various situations connected to how dissolved oxygen gets into the water. This section was designed to challenge students to 
think critically about content from the module, such as aeration, diffusion, plant byproducts (Appendix A).

Labs. Stream tables were used to create a watershed for analysis and application of vocabulary. Discussion of observations and applicable terms indicated student ability to correctly apply vocabulary terms to the stream model. Further teacher-guided explanations helped re-teach missed vocabulary, and then students were able to respond to how terms applied to the model structures. The stream activity was fun and interesting, according to student comments at the end of the school day. Re-teaching also occurred during a fast-paced Jeopardy-style review where students had opportunity to "rebound" missed questions. Discussion followed questions missed by the class. Although some planned details were eliminated from instruction due to unexpected time constraints, students were still able to apply knowledge as educated guesses. This was not the original plan, but students synthesized responses as they applied basic knowledge gained during this unit.

Despite knowledge gains and observed enthusiasm and positive comments following activities, postsurvey scores did not indicate attitude improvement following water quality instruction. 


\section{Chapter Five - Conclusion}

\section{Overview of Research Results}

The educational focus of this research was how students learn, synthesize information, and apply it to real world contexts. Instruction included inquiry, discovery and experiments followed by scientific water quality research applied in the classroom. Various assessments monitored student progress during inquiry-based instruction, which resulted in students attaining state and national standards concerning water quality. This was shown by gains in knowledge and understanding that followed inquiry-based instruction. However, the attitude survey was not as conclusive about student motivation to learn during inquiry activities. From survey scores, more significant gains in attitude were seen with interested individuals rather than with entire class periods. Assessments indicated improvements in "constructing and reflecting on scientific knowledge" concerning more specific themes (generative topics) within the water unit. Students did demonstrate 'better' understanding on certain objectives but not on others (Table 8) for gains according to each objective. Opportunities were provided for motivated students to redo work, which improved their learning. Since the modules were used to build knowledge and apply understanding of knowledge, students re-worked the activity until it was completed correctly. This "re-teach" method promoted positive results in learning as misconceptions were addressed.

Gains in knowledge did not occur with certain objectives (Table 8) because of 1) difficult concepts, 2) unfamiliar terminology, and 3) interrupted schedule of instruction. 
1) Instruction addressed middle level concepts, but also extended into general high school concepts outlined on the MDE Benchmarks (Table 8). Items that correlated to high school benchmarks addressed basic, more general context of these benchmarks (Table 4). These details were included as research into how students respond to difficult concepts along with effectiveness of learning through inquiry. Students were not expected to understand the details, yet students with 'good understanding' of the topic were challenged to apply knowledge to more difficult questions. Hence, less successful completion of the difficult items occurred because middle school students were not expected to understand those items. Perhaps the unit included higher expectations (HS objectives) that didn't actually challenge students as planned, but rather frustrated them enough to become unfocused.

2) New terminology challenged middle level students on the computer tutorial and knowledge test (Appendix A). Confusion was usually due to struggles with the new terminology and with reading comprehension skills for the computer modules. How questions were written and interpreted by respondents also influenced assessment scores. For example, test questions included terms that students were expected to learn through inquiry. After students asked for clarification of wording on questions, such as "degraded" in a question, I became concerned about the results testing their understanding of the topic: were responses missed because of misunderstanding concepts or because of misunderstanding the question? With the assumption that students asked for clarification, when they didn't understand, the question, test results could be less representative of learning. 
3) Instruction on selected objectives was inadequate because of interruptions in the daily schedule that interfered with inquiry-instruction and student discovery time. Instruction was planned for two weeks (Table 2) but required more time to develop inquiry activities. Students were unable to answer correctly on certain items because they did not learn the concepts or were unfamiliar with terminology in those questions. The objective for test item \#12 was not 'met' because it related to a laboratory activity that was only completed with Mrs. Theresa Legg's special education (S.E.) period. Negative gains resulted after instruction for test items \#2, 8,15 (Table 7) despite 'met' objectives (Table 8) because these items measured 'understanding' and 'application' of knowledge (Table 4). Item \#8 also pertained to water temperature and stratification (layers) that affect dissolved oxygen levels, which was not adequately addressed during instruction.

\section{Problems and Improvements}

Problems included inquiry as time intensive, large class sizes affect learning through inquiry, and teacher experience for effectively implementing inquiry-based instruction. I addressed the problems by using the MEECS video "After the Storm" to "re-teach" water quality and best practices to improve water quality. Students worked in pairs to create a list of "Top 10" water quality concerns that demonstrated learned concepts. As students completed this "ongoing assessment" (Wiske, 1998) or "continuous assessment" (Gallagher, 2000), they discussed the activities from previous class periods and recalled specific examples from the video, computer modules, and laboratory activities. This activity would be effective before the posttest, particularly when "Students enjoy the social aspects of science activities; for example, they enjoy the student-student and 
student-teacher interactions in group activities and open-ended laboratories and visits to science museums" (George \& Kaplan, 1998, p.104). Students seemed more interested in the small discussion groups that I individually addressed to offer further explanations and challenge any misconceptions.

Large classes pose many challenges to teachers' instruction using inquiry. An array of skills and abilities must be accommodated in a general education classroom. Teachers attempt to simultaneously reach all students performing at various levels. But it is difficult to increase students' knowledge base, let alone to teach for understanding as the educational models outline. Although teaching for understanding and personalizing learning for each student is the ideal way to educate students, it is not easily achieved as teachers juggle time, required concepts, and individual needs of students. From this research I learned more guidance might be necessary when middle level students learn new concepts through inquiry-based instruction. Students should have more structure with guided inquiry and more follow-through of ideas after activities, even when students apparently understand.

Another recommendation for improvement is to include Michigan Technological University web-modules (Auer, 2003) for my students because they provide local and therefore personal connections to science concepts. These modules are developed for one class period, cover the content in this unit, and provide additional reinforcements for understanding throughout the modules. In order to facilitate data analysis, students should also test the dissolved oxygen (DO) and temperature of a local water body, such as the pond near the school, to understand how the test is performed and how to interpret 
the test results. Students would then refer to the Dollar Bay data and analyze the general trends in DO and temperature in Dollar Bay.

\section{Future Studies}

Although research data indicated inquiry is an effective approach for students, I recommend further investigation into the effectiveness of inquiry-based learning for middle level students. This age level is unique: they require some guidance, especially with reading comprehension. Based on the implementing the water quality unit with nonmainstreamed grade seven special education science students, further investigation into the implications of inquiry with students that are "below average" would be educationally significant. State requirements include improving the performance of low-level students on standardized assessments. Further research into inquiry with low-level students would be insightful for accommodating students who struggle with learning and have poor attitudes about learning. Adjustments in curriculum based on educational research would be a powerful tool for educators.

Studies regarding training educators to implement inquiry would advance inquiry-based instruction. Implementing inquiry is difficult because teachers involve students in the learning process but tend to have little training in how to proceed. Untrained teachers aren't as effective with implementing inquiry-based instruction until they become experienced in the method (Furtak, 2006). This problem is compounded when the results of inquiry activities are unknown to the teacher.

Teaching with inquiry is "difficult to enact and limited... because of constraints such as teachers' lack of time, weak understanding of the nature of science, inappropriate curricula, and lack of pedagogical skills, leading to a perception of 
scientific inquiry as an amorphous teaching method that is difficult to implement" (Furtak, 2006, p.454).

Thus, teachers need better guidelines about the inquiry instruction: how to effectively "negotiate the space between the answers directed by the curriculum and the ideal form of scientific inquiry" (Furtak, 2006, p.455). Teachers also need better guidelines for handling questions that arise, especially when directing students in guided scientific inquiry activities (Furtak, 2006, p.455). The difficulty lies with how teachers get students to discover answers known by the teacher without the teacher providing too much assistance, revealing answers, or frustrating students. For an authentic inquiry experience teachers "withhold answers from their students" but educational models don't provide ways to "manage problems with answers when they arise" (Furtak, 2006, p.465).

\section{Educational Implications}

As science concepts are addressed in-depth, they become more abstract, more difficult and less interesting for most students. Therefore, science attitudes become more negative with older students (Pell \& Jarvis, 2001). Elementary concepts are basic and more real world; middle level begins to introduce more detail when building upon science knowledge. Middle level also introduces more abstract concepts, and many young students experience difficulty when trying to understand the abstract. Teachers can approach abstract science concepts to help students understand, but the natural curiosity that goes along with the nature of science is not fostered with the abstract. This project contributes to furthering educational research regarding teaching with inquiry because it entails middle level science instruction, which is less documented than 
other educational levels. From this investigation middle level students are capable of learning through inquiry, though more explanation is needed for students to make connections and apply knowledge. Even top students required additional explanation for applications of knowledge. However, students personalizing concepts through real-world laboratory experience results in positive attitude and achievement (1997, Moore; Freedman, 1997). One could make the argument that if laboratory experience causes positive results, then more laboratory activity would equate to more positive attitudes and achievement. How much laboratory experience compared to instruction time is not apparent from my review of literature or data collection. However, from student responses and survey results, laboratory time alone was insufficient and "more explanation would be helpful." There must be a balance in instructional methods, and an 'ideal ratio' of inquiry versus instruction time would be helpful. Furtak recommended a ratio of "two-third large-group discussion and one-third small group work" and included "opportunities for teachers to reflect on the existence of answers in their teaching and how they addressed these answers" (p.257). More data regarding this ratio would benefit teachers and students during the learning process.

After learning about various methods and models I wanted to know which is best to use. After gaining experience in classroom instruction I realized how similar the models are: there is not a 'best model' to follow. Rather, one can synthesize the models by 'similar intentions': they each attempt to direct inquiry-based instructional practices and directly involve students in the learning process. Some models are more user-friendly in their simplicity: Mercedes, Wiske, and 5E Learning Cycle. Fundamentally they are similar to state and national benchmarks; however, they consist of fewer steps that allow teachers to 
keep track of objectives while students learn. It is my goal to encourage students to become active, involved learners who connect what is learned in class to applications outside of class. National and state standards also promote this objective for meaningful and effective education. I gained a better understanding of inquiry by synthesizing existing educational models and research, just as the educational models suggest students do when learning. The educational implications for this new understanding is to modify how I teach in order to integrate inquiry in as many forms and as often as possible. The benefits of analyzing a unit I developed are many: most importantly I can prove whether my instruction is as effective as intended.

The investigation into middle school students learning with inquiry-based instruction for a water quality unit applied aspects of several educational methods and models. With the teacher as facilitator rather than as the provider of knowledge, students became actively involved learners. This process was more demanding than the average student was accustomed to. Furthermore, the trials and tribulations experienced during the process affect student attitudes; therefore, separating these influences from attitudes pertaining to the activities becomes difficult. Students interested in the subject matter could be uncomfortable with the demands of inquiry. Attitude assessment doesn't differentiate among extraneous factors, which would create unexpected or inconclusive results. Differentiating causes of attitudes was difficult, yet it advances understanding of how middle level students learn. 


\section{References}

American Association for the Advancement of Science (AAAS). (1993). Benchmarks for Science Literacy. Oxford University Press. Oxford.

Auer, M. (2003). Lake Restoration by Aeration (Online Learning Module). Michigan Technological University: Houghton, Michigan. http://techalive.mtu.edu/modules/module0001_alt/title.htm

Bracey, G. W. (2000). Differentiate Practical and Statistical significance. Bail Me Out: Handling Difficult Data and Tough Questions about Public Schools (pp. 58-62). Thousand Oaks, CA: Corwin Press.

Chang, Chun-Yen; Mao, Song-Ling. (1998). The Effects of an Inquiry-Based Instructional Method on Earth Science Students'Achievement. Paper presented at the Annual Meeting of the National Association for Research in Science Teaching (71 ${ }^{\text {st }}$, San Diego, CA, April 19-22, 1998).

Chinn, Clark A \& Hmelo-Silver, Cindy E. (2002). Authentic Inquiry: Introduction to the Special Section. Science Education, Vol.86, No.2, pp.171-174.

Chinn, C.A. \& Malhotra, B.A. (2002). Epistemology Authentic Inquiry in Schools: A theoretical framework for evaluating inquiry tasks. Science Education, Vol.86, No.2, 171-174.

Dodson, Stanley. (2005). Introduction to Limnology. McGraw Hill Companies. Inc. New York, NY.

Driver, Rosalind, et al. (1994). Making Sense of Secondary Science: research into children's ideas. Routledge, New York, NY. 
Freedman, Michael P. (1997). Relationship among Laboratory Instruction, Attitude toward Science, and Achievement in Science Knowledge. Journal of Research in Science Teaching. Vol.34, No.4, pp. 343-357.

Furtak, Erin Marie. (2006). The Problem with Answers: An Exploration of Guided Scientific Inquiry Teaching. Science Education, Vol.90, No.4, pp. 453-467. Gallagher, James. (2000). Teaching for Understanding and Application of Science Knowledge. School of Science and Mathematics, Vol. 100, No. 6, pp. 300-318.

George, Rani \& Kaplan, David. (1998). A Structural Model of Parent and Teacher Influences on Science Attitudes of Eighth Graders: Evidence from NELS: 88. Science Education, Vol.82, No.1, pp. 93-109.

Germann, Paul J. (1991). Developing Science Process Skills Through Directed Inquiry. American Biology Teacher. Vol.53, No.4, pp. 243-247.

Jarvis, Tina \& Pell, Anthony. (2002). Effect of the Challenger Experience on Elementary Children's Attitudes in Science. Journal of Research in Science Teaching. Vol.39, No.10, pp. 979-1000.

Keeves, J.P. (1975). The Home, the School, and Achievement in Mathematics and Science. Science Education, Vol.59, Vol.4, pp.439-460.

Michigan Department of Education (MDE). Michigan Curriculum Framework Science Benchmarks (MCF). (1996, 2000). http://cdp.mde.state.mi.us/mcf/ and www.michigan.gov/documents/Michigan CurriculumFramework

Misti, Frank L. Jr.; Shrigley, Robert L. \& Hanson, Lyle. (1991). Science Attitude Scale for Middle School Students. Science Education., Vol.75, No.5, pp.525-540. 
Margerum-Leys, Jon; Fishman, Barry J. \& Peek-Brown, Deborah. (2004). Lab Partners. National Staff Development Council, Vol.25, No.4, pp. 38-42. www.nsdc.org Matthews, M.R. (2000). Time for Science Education: How Teaching the History and Philosophy of Pendulum Motion can Contribute to Science Literacy (Innovations in Science Education and Technology). Kluwer Academic / Plenum Publishers, New York, NY.

Michigan Environmental Education Curriculum Support (MEECS). (2005). Central Michigan University Printing Services. Mt. Pleasant, MI.

Mills, Geoffrey E. (2003). Action Research: A Guide for the Teacher Researcher. Pearson Education, Inc. Upper Saddle River, New Jersey.

Moore, Richard W. \& Foy, Rachel Leigh Hill. (1997). The Scientific Attitude Inventory: A Revision (SAI II). Journal of Research in Science Teaching. Vol.34, No.4, pp. 327-336.

National Academy of Sciences (NAS). (1998). Teaching about Evolution and the Nature of Science. National Academy Press. Washington, D.C.

National Research Council (NRC). (1996). National Science Education Standards. National Academy of Press. Washington, D.C.

National Research Council (NRC). (2000). Inquiry and the National Science Education Standards: A Guide for Teaching and Learning. National Academy of Press. Washington, D.C.

Partnership for Environmental Education and Rural Health (PEER) Curriculum. (2001). Modules: Dissolved Oxygen and Temperature. Texas A\&M University. http://peer.tamu.edu/curriculum_modules/Water_Quality/ 
Pell, Tony \& Jarvis, Tina. (2001). Developing Attitude to science scales for use with children of ages from five to eleven years. International Journal of Science Education, Vol.23, No.8, pp. 847-862.

Rudolf, John L. (2005). Inquiry and the Public Understanding of Science. Science Education, Vol.89, pp. 803-821.

Rutherford, F. J., \& Ahlgreen, A. (1990). Science for All Americans: Project 2061 (American Association for the Advancement of Science). New York, NY: Oxford University Press, Inc.

Sandoval, William A. (2005). Understanding Students' Practical Epistemologies and Their Influence on Learning Through Inquiry. Science Education, Vol.89, pp. 634-656.

Shaver, J.P. (1985). Chance and nonsense: A conversation about interpreting tests of statistical significance, part 1. Phi Delta Kappan, 67, 57-60.

Shymansky, J. A., Hedges, L. V. \& Woodworth, G. (1990). A reassessment of the effects of inquiry-based science curricula of the 60's on student performance. Journal of Research in Science Teaching, 27(2), 127- 144.

Stamp, Nancy \& O'Brien, Thomas. (2005). GK-12 Partnership: A Model to Advance Change in Science Education. Bioscience, Vol.55, No.1, pp. 70-76.

Tan, Seng Chee; Yeo, Ai Choo Jennifer \& Lim, Wei Ying. (2005). Changing Epistemology of Science Learning through Inquiry with Computer-Supported Collaborative Learning. Journal of Computers in Mathematics and Science Teaching, Vol.24, No.4, pp. 367-386. 
Western UP Center for Science, Mathematics and Environmental Education (WUPCMEE). (2005). Western Upper Peninsula Science Fair: Student Planning Guide, Grades 6-9. Michigan Technological University. Houghton, MI. http://www.wupcenter.mtu.edu .

Wiggins, Grant \& McTighe, Jay. (1998). Understanding by Design. Association for Supervision and Curriculum Development. Alexandria, VA.

Wiske, M.S. (Ed.). (1998). Teaching for Understanding: Linking research with practice. Jossey-Bass Publishers. San Francisco, CA.

White, R.T. \& Gunstone, R.F. (1992). Probing Understanding. The Falmer Press. Philadelphia, PA. 
(This page is deliberately blank) 


\section{Appendix A - Instructional Unit}


(This page is deliberately blank) 
Days 1 and 10.

\section{Attitude Assessment: Presurvey \& Postsurvey}

PROJECT ID NUMBER

MALE or FEMALE

GRADE

Complete the table by circling the statement that best reflects your opinion.

\begin{tabular}{|c|c|c|c|c|c|}
\hline 1. Education is... & $\begin{array}{l}\text { NEVER } \\
\text { Important }\end{array}$ & $\begin{array}{c}\text { NOT } \\
\text { Important }\end{array}$ & $\begin{array}{l}\text { Sometimes } \\
\text { Important }\end{array}$ & $\begin{array}{c}\text { OFTEN } \\
\text { Important }\end{array}$ & $\begin{array}{l}\text { VERY } \\
\text { Important }\end{array}$ \\
\hline 2. $\quad$ Science is... & $\begin{array}{l}\text { NEVER } \\
\text { Important }\end{array}$ & $\begin{array}{c}\text { NOT } \\
\text { Important }\end{array}$ & $\begin{array}{l}\text { Sometimes } \\
\text { Important }\end{array}$ & $\begin{array}{l}\text { OFTEN } \\
\text { Important }\end{array}$ & $\begin{array}{c}\text { VERY } \\
\text { Important }\end{array}$ \\
\hline 3. Science is... & $\begin{array}{l}\text { NEVER } \\
\text { Enjoyable }\end{array}$ & $\begin{array}{l}\text { RARELY } \\
\text { Enjoyable }\end{array}$ & $\begin{array}{l}\text { Sometimes } \\
\text { Enjoyable }\end{array}$ & $\begin{array}{c}\text { OFTEN } \\
\text { Enjoyable }\end{array}$ & $\begin{array}{l}\text { USUALLY } \\
\text { Enjoyable }\end{array}$ \\
\hline 4. Learning science is... & $\begin{array}{l}\text { USUALLY } \\
\text { Difficult }\end{array}$ & $\begin{array}{l}\text { OFTEN } \\
\text { Difficult }\end{array}$ & $\begin{array}{l}\text { Somewhat } \\
\text { Difficult }\end{array}$ & $\begin{array}{l}\text { OFTEN } \\
\text { Easy }\end{array}$ & $\begin{array}{c}\text { USUALLY } \\
\text { Easy }\end{array}$ \\
\hline $\begin{array}{l}\text { 5. I will watch science programs } \\
\text { or read science stories... }\end{array}$ & NEVER & $\begin{array}{l}\text { RARELY } \\
\text { now \& then }\end{array}$ & Sometimes & OFTEN & $\begin{array}{l}\text { WHENEVER } \\
\text { possible }\end{array}$ \\
\hline $\begin{array}{l}\text { 6. I like discovering information } \\
\text { on my own }\end{array}$ & $\begin{array}{l}\text { Strongly } \\
\text { Disagree }\end{array}$ & Disagree & Uncertain & Agree & $\begin{array}{l}\text { Strongly } \\
\text { Agree }\end{array}$ \\
\hline $\begin{array}{l}\text { 7. I learn best when I listen to } \\
\text { explanations about information }\end{array}$ & $\begin{array}{l}\text { Strongly } \\
\text { Disagree }\end{array}$ & Disagree & Uncertain & Agree & $\begin{array}{l}\text { Strongly } \\
\text { Agree }\end{array}$ \\
\hline $\begin{array}{ll}\text { 8. } & \text { I learn best when I read } \\
\text { information on my own }\end{array}$ & $\begin{array}{l}\text { Strongly } \\
\text { Disagree }\end{array}$ & Disagree & Uncertain & Agree & $\begin{array}{l}\text { Strongly } \\
\text { Agree }\end{array}$ \\
\hline $\begin{array}{l}\text { 9. I learn best when I am active } \\
\text { and can do hands-on activities }\end{array}$ & $\begin{array}{l}\text { Strongly } \\
\text { Disagree }\end{array}$ & Disagree & Uncertain & Agree & $\begin{array}{l}\text { Strongly } \\
\text { Agree }\end{array}$ \\
\hline $\begin{array}{l}\text { 10. I would enjoy visiting a } \\
\text { science center in my free time }\end{array}$ & $\begin{array}{l}\text { Strongly } \\
\text { Disagree }\end{array}$ & Disagree & Uncertain & Agree & $\begin{array}{l}\text { Strongly } \\
\text { Agree }\end{array}$ \\
\hline $\begin{array}{l}\text { 11. I like science more than other } \\
\text { subjects in school }\end{array}$ & $\begin{array}{l}\text { Strongly } \\
\text { Disagree }\end{array}$ & Disagree & Uncertain & Agree & $\begin{array}{l}\text { Strongly } \\
\text { Agree }\end{array}$ \\
\hline $\begin{array}{l}\text { 12. I like teachers asking } \\
\text { questions so I can figure thing } \\
\text { out, instead of telling me } \\
\text { answers } \\
\end{array}$ & $\begin{array}{l}\text { Strongly } \\
\text { Disagree }\end{array}$ & Disagree & Uncertain & Agree & $\begin{array}{l}\text { Strongly } \\
\text { Agree }\end{array}$ \\
\hline $\begin{array}{l}\text { 13. I would be happy if my future } \\
\text { career requires me to use } \\
\text { science }\end{array}$ & $\begin{array}{l}\text { Strongly } \\
\text { Disagree }\end{array}$ & Disagree & Uncertain & Agree & $\begin{array}{l}\text { Strongly } \\
\text { Agree }\end{array}$ \\
\hline 14. I am good at science & $\begin{array}{l}\text { Strongly } \\
\text { Disagree }\end{array}$ & Disagree & Uncertain & Agree & $\begin{array}{l}\text { Strongly } \\
\text { Agree }\end{array}$ \\
\hline $\begin{array}{l}\text { 15. What I learn in science class } \\
\text { applies to life outside of school }\end{array}$ & $\begin{array}{l}\text { Strongly } \\
\text { Disagree }\end{array}$ & Disagree & Uncertain & Agree & $\begin{array}{l}\text { Strongly } \\
\text { Agree }\end{array}$ \\
\hline $\begin{array}{l}\text { 16. My semester grade in science } \\
\text { is usually... }\end{array}$ & $\mathrm{E}$ & $\mathrm{D}$ & $\mathrm{C}$ & B & A \\
\hline $\begin{array}{l}\text { 17. The best thing about learning } \\
\text { science is... }\end{array}$ & & & & & \\
\hline $\begin{array}{l}\text { 18. The hardest thing about } \\
\text { learning science is... }\end{array}$ & & & & & \\
\hline $\begin{array}{l}\text { 19. In science, I would like to } \\
\text { learn more about... }\end{array}$ & & & & & \\
\hline $\begin{array}{l}\text { 20. The best thing I've ever done } \\
\text { in science class was... }\end{array}$ & & & & & \\
\hline $\begin{array}{l}\text { 21. Teachers can help me learn } \\
\text { better by... }\end{array}$ & & & & & \\
\hline
\end{tabular}


Days 1 and 10.

\title{
Knowledge Assessment: Pretest \& Posttest
}

\author{
PROJECT ID NUMBER \\ MALE or FEMALE \\ GRADE
}

1. Which of the following is the best way to determine the health of a stream?

A. Measure $\mathrm{pH}$ and temperature of water

B. Count the number of macroinvertebrates living in the stream

C. Count the number and types of plant species near the stream

D. Estimate the amount of sand versus gravel on the channel bottom

E. Measure the width and depth of the stream channel

2. Only pollution-tolerant macroinvertebrates are detected in a stream. This indicates...
A. Water quality has been degraded.
B. The sensitive species were eaten.
C. Conditions in the stream are ideal for cold-water fish species, such as trout
D. You can drink the water.
E. You don't need to test any other parts of the stream.

3. Which of the following is an example of a non-point source pollutant?
A. The water from a sewage treatment plant flows out of a pipe directly into a lake.
B. Runoff carrying fertilizers, pesticides, and sediment from a lawn into a river.
C. Polluted discharge from a factory
D. Sediment entering a river from an eroded bank
E. Storm-water runoff discharging from a culvert (carrying sediment, pet wastes, gasoline, and used motor oil)

4. Which of the following land cover types would have the GREATEST runoff?
A. Corn field
B. Marsh
C. Dense forest
D. Parking lot
E. Green lawn

5. Bioaccumulation: Why encourage people to limit consumption of fish from the Great Lakes?
A. Fish have a lot of cholesterol
B. Over-fishing is a big problem in the Great Lakes, so catch and release is best
C. Pollutants that build up in fish can affect human health
D. The Great Lakes are clean, so you don't need to limit your fish consumption
E. We need to leave enough fish for the sea lamprey to eat

\section{Circle which option on the right that correctly completes the sentence.}

\begin{tabular}{ll}
$\begin{array}{l}\text { 6. Water at cold temperature has... } \\
\text { 7. Water at } 4^{\circ} \mathrm{C} \text { is... }\end{array}$ & $\begin{array}{l}\text { (more, less, constant) DO } \\
\text { (most, more, less) dense }\end{array}$ \\
\hline 8. The colder layer of water is the... & $\begin{array}{l}\text { (top, middle, bottom) layer } \\
\text { (epilimnion, hydrolimnion, } \\
\text { thermocline) }\end{array}$ \\
\hline $\begin{array}{l}\text { 9. Top layer of stratified water is the... } \\
\text { 10. Water having constant temperature with depth is... }\end{array}$ & $\begin{array}{l}\text { (stratified, mixed) } \\
\text { 11. High bacteria levels in water cause DO levels to... } \\
\text { (increase, decrease, not } \\
\text { change) }\end{array}$ \\
\hline
\end{tabular}


12. Which statement is TRUE about fish and dissolved oxygen?

A. Fish remove oxygen from the atmosphere by swallowing air bubbles.

B. Fish remove oxygen from the water by using gills.

C. Fish do NOT use oxygen, so the amount of dissolved oxygen does not matter.

D. Fish can breathe with lungs when they need to.

13. The amount of dissolved oxygen in water will increase by adding
A. Plants
B. Heat
C. Fish
D. Bacteria
E. Dams

14. For a year, you monitor the levels of dissolved oxygen in five bodies of water. Which would have the highest average levels of dissolved oxygen?
A. A mountain lake with many aquatic plants
B. A rapid flowing stream at the base of a mountain
C. A slow moving river
D. A stagnant pond
E. An underground river (aquifer)

15. The best way to correct a pond that has unstable levels of dissolved oxygen would be to...
A. Add fertilizer to the pond
B. Add algae to the pond
C. Add fish to the pond
D. Pump air into the pond
E. Expose the pond to direct sunlight

16. Which of the following would NOT increase the amount of dissolved oxygen in water?
A. Diffusion from the atmosphere
B. Bacteria in the water
C. Plants in the water
D. Rapid movement of water over rocks
E. Algae in the water

17. You notice many different kinds of dead fish floating on the surface of a large lake. Which one of the following events most likely happened?
A. The fish died when bacteria in the water infected them.
B. The fish were poisoned from nitrates in the water.
C. The fish suffocated when dissolved oxygen levels dropped below $2.0 \mathrm{mg} / \mathrm{L}$.
D. The fish ate algae and died from toxins produced by the algae.
E. The fish could not breed. The temperature of the lake was too low for reproduction.

18. Your tests for nitrate and phosphate indicate very high levels. What color is the water?
A. Yellow
B. Green
C. Brown
D. Blue
E. Red

19. Why would the water change color with high nitrates and phosphates?
A. The temperature is higher
B. There is more bacteria
C. There is more algae
D. There is more waste from organisms
E. There is more ammonia 
20. Which statement is true about the $\mathrm{pH}$ scale?
A. The $\mathrm{pH}$ scale measures the concentration of Hydrogen.
B. The $\mathrm{pH}$ scale goes from -14 to 14 .
C. Lower numbers on the scale are basic; higher are acidic.
D. $\mathrm{A} \mathrm{pH}$ of 10 is a neutral solution

21. Which is indirectly affected by having extra nitrate in the water?
A. Turbulence
B. Temperature
C. Bubbles
D. Dissolved Oxygen

The following information is used for \#22-25.

As a research scientist with the Environmental Protection Agency, you monitor rivers in areas near companies. You measure the amount of dissolved oxygen in the water, and receive the following results.

\begin{tabular}{|l|l|l|}
\hline River & Company & Dissolved Oxygen \\
\hline Apple River & Apple Sewage Treatment & $6 \mathrm{mg} / \mathrm{dL}$ \\
\hline Big River & Big River Golf Course & $9 \mathrm{mg} / \mathrm{dL}$ \\
\hline Chattanooga River & Chattanooga Dam \& Electric Plant & $14 \mathrm{mg} / \mathrm{dL}$ \\
\hline Durham River & Durham Fertilizer Plant & $10 \mathrm{mg} / \mathrm{dL}$ \\
\hline East River & East River Sawmill & $4 \mathrm{mg} / \mathrm{dL}$ \\
\hline
\end{tabular}

22. One of the values from the data table (above) concerns you.

Which company do you suspect is causing problems?
A. Apple Sewage Treatment
B. Big River Golf Course
C. Chattanooga Dam and Electric Plant
D. Durham Fertilizer Plant
E. East River Sawmill

23. WHY do you suspect this company (identified in \#22)?

$24 \& 25$. Answer in complete sentences.

Devise a plan to protect Michigan's water resources.

Recommend $\mathbf{2}$ specific actions: state why each action is necessary.

One action is

Another action is 
DAYS 2-3.

Guided Inquiry for Measuring Water Quality Name Project ID\#

Focus Questions: How is water quality measured? How accurate (or limiting) is this? Module Website: http://peer.tamu.edu/curriculum modules/Water Quality/ Module \# 2, Temperature Then, Skip ahead to "Presentation"

1. How does water temperature affect the quality of a river or stream? List 4 ways.
A.
B.
C.
D.

2. How does water temperature affect Dissolved Oxygen in the water?

A. As temperature increases,

B. As temperature decreases,

3. Graphing. Use data from the module to complete the following graphs on graphing paper.

A. Graph 'Temperature'. Plot Temperature $\left({ }^{\circ} \mathrm{C}\right)$ on the x-axis. Plot Temperature $\left({ }^{\circ} \mathrm{F}\right)$ on the y-axis.

B. Graph 'Temperature' versus 'Dissolved Oxygen'. Plot Temperature $\left({ }^{\circ} \mathrm{C}\right)$ on the $\mathrm{x}$ axis and Dissolved Oxygen $(\mathrm{mg} / \mathrm{L})$ on the $y$-axis.

\section{Analysis}

A. Review the graphs from the Temperature module. Note the linear relationship of temperature conversions between ${ }^{\circ} \mathrm{C}$ and ${ }^{\circ} \mathrm{F}$.

B. Note the shape of the line for ${ }^{\circ} \mathrm{C}$ versus DO. It is not linear.

C. On the graph of ${ }^{\circ} \mathrm{C}$ versus DO, draw and label DO levels for cold-water organisms and warm-water organisms. Draw a line at $1.5 \mathrm{mg} / \mathrm{L}$ and label the line 'fish kill'.

D. On the graph of ${ }^{\circ} \mathrm{C}$ versus DO, plot the maximum DO levels that can occur at each temperature (from the table below).

\begin{tabular}{|l|l|l|l|l|l|l|l|l|l|l|l|l|l|l|l|l|}
\hline \multicolumn{11}{|c|}{ Maximum Dissolved Oxygen (DO) levels based on Temperature } \\
\hline${ }^{\circ} \mathrm{C}$ & 0 & 2 & 4 & 6 & 8 & 10 & 12 & 14 & 16 & 18 & 20 & 22 & 24 & 26 & 28 & 30 \\
\hline${ }^{\circ} \mathrm{F}$ & 32 & 36 & 39 & 43 & 46 & 50 & 54 & 57 & 61 & 64 & 68 & 72 & 75 & 79 & 82 & 86 \\
\hline DO & 14.6 & 13.8 & 13.1 & 12.4 & 11.8 & 11.3 & 10.8 & 10.3 & 9.9 & 9.5 & 9.1 & 8.8 & 8.5 & 8.2 & 7.9 & 7.6 \\
\hline
\end{tabular}

E. How does the maximum level of dissolved oxygen in water compare to the module's data of dissolved oxygen in a water body?

5. Application. After viewing the video Aquatic Invertebrates and Water Quality, complete the following questions.

A. What are "aquatic invertebrates"?

These organisms can also be called "macroinvertebrates".

B. Where do "benthic" macroinvertebrates live?

These organisms are "bioindicators".

C. List examples of organisms (fish AND insects) that prefer cooler water:

This group of organisms is called "cold water organisms".

D. List examples of organisms (fish AND insects) that prefer warmer water:

This group of organisms is called "warm water organisms".

6. Discussion. Temperature affects water quality because it determines Dissolved Oxygen levels. Cooler water has more DO, cold-water organisms, and pollution-sensitive macroinvertebrates. Warmer water has less DO, warm-water organisms, and pollutiontolerant macroinvertebrates. 
DAYS 3-5.

NAME PROJECT ID \#

Guided Inquiry for Measuring Water Quality

Focus Questions: How is water quality measured? How accurate (or limiting) is this?

Module Website: http://peer.tamu.edu/curriculum_modules/Water_Quality/

\section{Module \#3: Measuring Dissolved Oxygen (DO)}

1. Name 3 ways oxygen gets into the water.

A.

B.

C.

2. How does the amount of oxygen differ for every body of water? List 3 ways

A.

B.

C.

3. How much dissolved oxygen is needed for ...

A. cold-water organisms?

B. warm-water organisms?

4. What happens to aquatic organisms when DO is less than $1.5 \mathrm{mg} / \mathrm{L}$ ?

5. Illustrate and Label. Include items from the list on the lake below.

\section{List of Terms}

Biological
A. Bacteria
B. Fish
C. Aquatic plants
D. Algae
E. Aquatic insects
F. Organic material (e.g.)
G. Organic material (e.g.)

Chemical - sources

$\mathrm{H}$. Oxygen

I. Nitrates

J. Phosphates

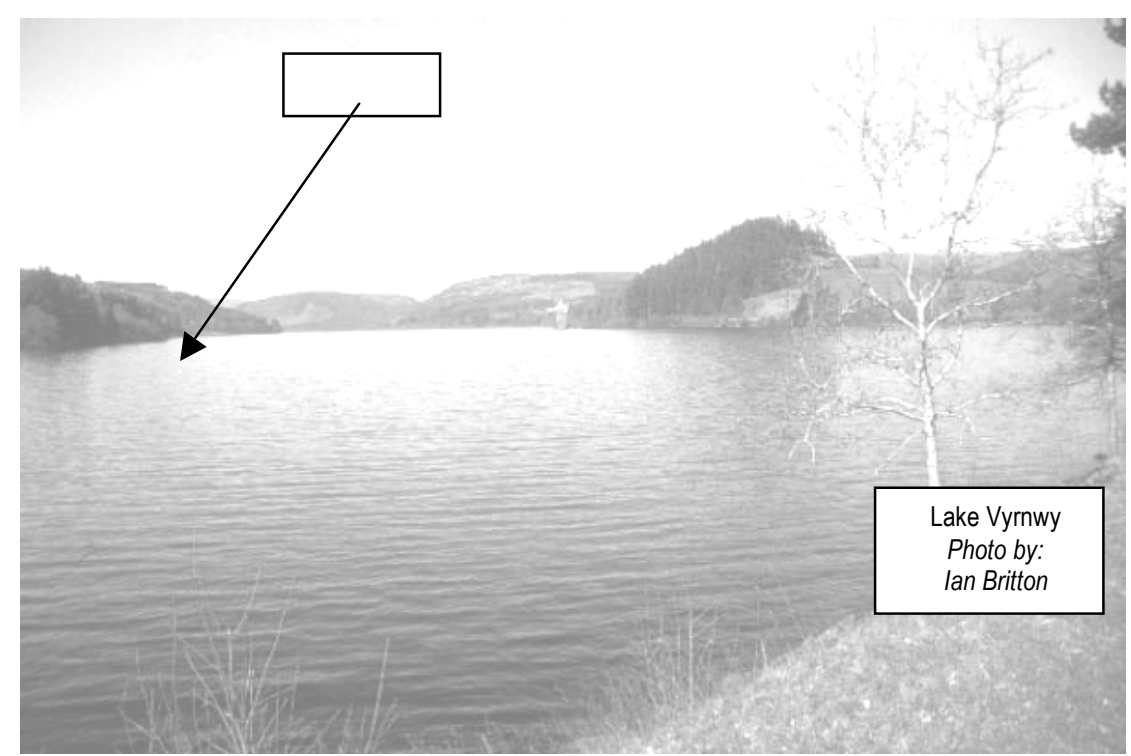


Predict what would happen to the lake if you changed its location.

Use information from the website's Module to complete the table below.

\begin{tabular}{|l|l|l|}
\hline $\begin{array}{l}\text { NEW Location } \\
\text { for this lake }\end{array}$ & $\begin{array}{l}\text { DO changes } \\
\text { A. How? (increase, decrease) } \\
\text { B. Why? }\end{array}$ & $\begin{array}{l}\text { Surviving organisms? } \\
\text { Cold-water, example } \\
\text { OR } \\
\text { Warm-water, example }\end{array}$ \\
\hline $\begin{array}{l}\text { 6. Top of Mountain } \\
\text { (Less pressure) }\end{array}$ & $\begin{array}{l}\text { A. } \\
\text { B. }\end{array}$ & \\
\hline $\begin{array}{l}\text { 7. At the base of a } \\
\text { Whitewater River }\end{array}$ & $\begin{array}{l}\text { A. } \\
\text { B. }\end{array}$ & \\
\hline $\begin{array}{l}\text { 8. Near a farm } \\
\text { (Uses fertilizer \& } \\
\text { pesticides) }\end{array}$ & A. & \\
\hline $\begin{array}{l}\text { 9. After a dam } \\
\text { (Made by humans) }\end{array}$ & B. & \\
& B. & \\
\hline
\end{tabular}

\section{Module 4: Measuring pH.}

10. Label acid, base, neutral to make a pH Scale.

11. Click on the Acid Rain link. Summarize 2 things you learned about acid rain.

A.

B.

12. How does $\mathrm{pH}$ affect organisms in the water?

A.

B.

13. List 2 factors that change $\mathrm{pH}$ in bodies of water

A.

B.

\section{Module 5: Measuring Nitrates.}

14. Where do nitrates come from?

A.

B.

C

D

15. List affects nitrates have on the ecosystem

A.

B.

16. List affects of nitrates on water quality.

A.

B.

17. List affects of nitrates on human health

A.

B 
DAY 6.

Lab: "Looks Fishy”

source: "Water's the Matter"

website: http://peer.tamu.edu/curriculum_modules/Water_Quality/Teacherpages/Module_3/oxygen

\section{PROJECT ID NUMBER}

\section{Directions}

1. Fill in your predictions below, in column $A$.

2. Observe the fish in the Control aquarium; record data and observations in columns B \& $C$.

3. Carefully place fish in the Low aquarium; record data and observations in columns B \& $C$

4. Observe the fish in the Control aquarium; record data and observations in columns $B$ \& $C$

5. Carefully place fish in the HIGH aquarium; record data and observations in columns $B$ \& $C$

6 . Complete the analysis questions at the end of this LAB sheet. Use complete sentences.

Materials

Thermometer, Litmus paper, pH paper, goldfish, fish net, aquarium, aquarium air bubbler, large beakers, Clip boards, Dissolved Oxygen test kit

\section{DATA \& Observations}

\begin{tabular}{|c|c|c|c|c|}
\hline $\begin{array}{l}\text { Beaker } \\
\text { with } \\
\text { FISH }\end{array}$ & $\begin{array}{l}\text { A. Predicted } \\
\text { HYPOTHESIS } \\
\text { (behavior) }\end{array}$ & $\begin{array}{c}\text { Monitored } \\
\text { MOVEMENT }\end{array}$ & $\begin{array}{l}\text { B. DATA Observed } \\
\text { (\# in } 1 \mathrm{~min} .)\end{array}$ & $\begin{array}{l}\text { C. Observed } \\
\text { Behavior }\end{array}$ \\
\hline Control 1 & & Swishing of TAIL & & \\
\hline Control 2 & & Flexing of MOUTH & & \\
\hline Control 3 & & Flexing of GILLS & & \\
\hline LOW 1 & & Swishing of TAIL & & \\
\hline LOW 2 & & Flexing of MOUTH & & \\
\hline LOW 3 & & Flexing of GILLS & & \\
\hline HIGH 1 & & Swishing of TAIL & & \\
\hline HIGH 2 & & Flexing of MOUTH & & \\
\hline HIGH 3 & & Flexing of GILLS & & \\
\hline
\end{tabular}

\section{Data Analysis}

1. Compare and Contrast...

A. Behavior of fish as temperature changes

B. Results from LOW oxygen to the control

C. Results from HIGH oxygen to the control

2. From your observations and data, summarize how changes in Temperature affects levels of dissolved oxygen (DO).

Real-world Application

3. What other factors could affect the fish in this environment?

List 3 and Explain possible effects of these factors.

A.

B.

C.

Applying Knowledge. Explain how high salinity (salt) would affect the behavior of the fish. 
DAY 6-8.

Stream Lab and Affects of Pollution

Objectives:

Stream cutters: make a stream, observe what happens with "pollutant" Sources of Pollution: point source and non-point source

Community analysis: identify sources of pollution from different land uses

Materials: Stream beds, Water, Sand, Buildings \&/or people, Cotton ball dyed for toxic waste

Students cut streams by allowing water to flow from one spot for a few minutes. Students may experiment with variables and determine affects on stream.

Data and observations are recorded on the worksheet.

Students completed lab questions for homework (referring to their lab notes from class).

Directions: Record your answers on the lab activity worksheet.

Activity 1

1. Prepare stream table

2. Cut a stream

3. More cutting (to simulate changes over time)

4. People move in (towns)

5. Flooding occurs

6. Compare

Activity 2

1. Where is the toxic waste? Circle it.

2. Where is the waste going? Arrow to show.

3 . Where does the waste spread?

4. Which sites are affected by the pollution?

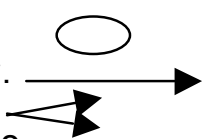

Extending knowledge with stream terms

1. Alluvial fan

2. Delta

3. Discharge

4. Erosion

5. Floodplain

6. Headwaters

7. Levee

8. Mouth

9. Runoff

10. Watershed

Application with land development:

1. Agriculture

2. Industry

3. Residential

4. Recreational

5. Waste management. 
NAME:

LAB: Stream Cutter

PROJECT \#:

\begin{tabular}{|c|c|c|}
\hline $\begin{array}{c}\text { Activity } \\
\text { Requirements }\end{array}$ & Sketches, Labeling, Observations & $\begin{array}{c}\text { Grade } \\
\vdots \\
\text { Points }\end{array}$ \\
\hline $\begin{array}{c}\text { Initial sketch of } \\
\text { the "land" }\end{array}$ & & 5 \\
\hline $\begin{array}{c}\text { Early stream } \\
\text { sketch } \\
\text { (after } 5 \text { minutes) }\end{array}$ & & 5 \\
\hline $\begin{array}{l}\text { Final stream } \\
\quad \text { sketch } \\
\text { (label to identify } \\
\text { pollutant source, } \\
\text { arrows to illustrate }\end{array}$ & & 5 \\
\hline $\begin{array}{l}\text { Tracking } \\
\text { Pollution } \\
\text { (on final sketch) }\end{array}$ & $\begin{array}{l}\text { 1. Where is the toxic waste source? } \\
\text { 2. Where is the waste going? } \\
\text { 3. Where does the waste spread? } \\
\text { 4. Which } 2 \text { sites are most affected by the pollution? } \mathbf{P}\end{array}$ & 5 \\
\hline $\begin{array}{l}\text { Label terms } \\
\text { (on final sketch) }\end{array}$ & $\begin{array}{l}\text { 1. Alluvial fan } \\
\text { 2. Delta } \\
\text { 3. Discharge } \\
\text { 4. Erosion } \\
\text { 5. Floodplain } \\
\text { 6. Headwaters } \\
\text { 7. Levee } \\
\text { 8. Mouth } \\
\text { 9. Runoff } \\
\text { 10. Watershed }\end{array}$ & 10 \\
\hline $\begin{array}{l}\text { Develop land } \\
\text { (label, final sketch) }\end{array}$ & $\begin{array}{l}\text { Where land along the stream would be used for... } \\
\text { 1. Agriculture } \\
\text { 2. Industry } \\
\text { 3. Recreational } \\
\text { 4. Residential } \\
\text { 5. Waste management }\end{array}$ & 5 \\
\hline $\begin{array}{l}\text { T.E.A.M. } \\
\text { score }\end{array}$ & $\begin{array}{c}\text { Together Everybody Assesses Me } \\
\text { Teamwork, Clean-up }\end{array}$ & 5 \\
\hline
\end{tabular}




\section{DAY 9.}

Conclusion: conclude with "Jeopardy"

Materials: Note cards for questions, Dice to roll

Directions: Students generate five questions, and assign value to each question. As a group (of 3-4), they direct a question to a different group. If the other group does not answer correctly it becomes open to be picked up by any remaining group. If it is missed again, the initiating group receives the assigned value. Refer to sample questions below.

\section{Figure 1. Jeopardy Review Game}

\begin{tabular}{|c|c|c|c|c|c|}
\hline & $\begin{array}{c}\text { Biological } \\
\text { Assessment }\end{array}$ & $\begin{array}{c}\text { Physical } \\
\text { Assessment }\end{array}$ & $\begin{array}{c}\text { Chemical } \\
\text { Assessment }\end{array}$ & $\begin{array}{l}\text { Pollution } \\
\text { Effects }\end{array}$ & Random $\mathrm{H}_{2} \mathrm{O}$ \\
\hline 100 & $\begin{array}{l}\text { These "buggy" } \\
\text { creatures reveal the } \\
\text { quality of streams. } \\
\text { Macroinvertebrates }\end{array}$ & $\begin{array}{l}\text { Vegetation along a } \\
\text { stream can improve } \\
\text { oxygen levels by } \\
\text { decreasing this } \\
\text { "measurement". } \\
\text { Temperature }\end{array}$ & $\begin{array}{l}\text { This measurement } \\
\text { indicates acidity of } \\
\text { water. or other } \\
\text { substances. } \\
\text { pH }\end{array}$ & $\begin{array}{l}\text { What do trash, oil, } \\
\text { fertilizer, and cow } \\
\text { manure all have } \\
\text { in common? } \\
\text { They are pollutant } \\
\text { (examples) }\end{array}$ & $\begin{array}{l}\text { The name for } \\
\text { the entire area } \\
\text { where water } \\
\text { flows. } \\
\text { Watershed }\end{array}$ \\
\hline 200 & $\begin{array}{l}\text { High levels of } \\
\text { these } \\
\text { microscopic } \\
\text { critters decrease } \\
\text { oxygen levels. } \\
\text { Bacteria }\end{array}$ & $\begin{array}{l}\text { A new stream may } \\
\text { be "cloudy" because } \\
\text { of these fine, dirty } \\
\text { particles. } \\
\text { Sediment }\end{array}$ & $\begin{array}{l}\text { This is another } \\
\text { name for "Salty" } \\
\text { water. } \\
\text { Saline, Salinity }\end{array}$ & $\begin{array}{l}\text { My driveway is } \\
\text { paved! What } \\
\text { made the nearby } \\
\text { creek "messier" } \\
\text { after it rained? } \\
\text { Run-off (more of } \\
\text { it with pavement) }\end{array}$ & $\begin{array}{l}\text { What is water that } \\
\text { has constant } \\
\text { temperature with } \\
\text { depth? } \\
\text { Mixed }\end{array}$ \\
\hline 300 & $\begin{array}{l}\text { Vegetation on the } \\
\text { shore can fall into the } \\
\text { body of water. What } \\
\text { is the resulting } \\
\text { "matter"? } \\
\text { Organic }\end{array}$ & $\begin{array}{l}\text { Why do oxygen } \\
\text { levels improve } \\
\text { where rivers and } \\
\text { streams have } \\
\text { rapids? } \\
\text { The turbulence } \\
\text { aerates (adding } \\
\text { oxygen from the air) }\end{array}$ & $\begin{array}{l}\text { This is inversely } \\
\text { related to water } \\
\text { temperature. } \\
\text { DO, "Dissolved } \\
\text { Oxygen" }\end{array}$ & $\begin{array}{l}\text { Oil leaking from a } \\
\text { boat motor is an } \\
\text { example of this } \\
\text { type of pollution. } \\
\text { Point source }\end{array}$ & $\begin{array}{l}\text { What is the metric } \\
\text { temperature equal } \\
\text { to } 32^{\circ} \mathrm{F} \text { ? } \\
0^{\circ} \mathrm{C}\end{array}$ \\
\hline 400 & $\begin{array}{l}\text { How and when do } \\
\text { plants affect DO } \\
\text { levels in a body of } \\
\text { water? } \\
\text { Produce oxygen, } \\
\text { daytime }\end{array}$ & $\begin{array}{l}\text { What color do } \\
\text { nitrates make water? } \\
\text { WHY? } \\
\text { Green because of } \\
\text { Algal blooms } \\
\text { (increase in Algae) }\end{array}$ & $\begin{array}{l}\text { Fertilizer affects } \\
\text { water quality by } \\
\text { increases the level } \\
\text { these } 2 \text { chemicals. } \\
\text { Name both. } \\
\text { Nitrates }-\& \text { - } \\
\text { Phosphates }\end{array}$ & $\begin{array}{l}\text { This type of } \\
\text { pollution enters } \\
\text { indirectly from } \\
\text { where it } \\
\text { originated. } \\
\text { Non-point source }\end{array}$ & $\begin{array}{l}\text { At which metric } \\
\text { temperature is } \\
\text { water most dense? } \\
4^{\circ} \mathrm{C}\end{array}$ \\
\hline 500 & $\begin{array}{l}\text { Name } 2 \text { specific } \\
\text { reasons why fish } \\
\text { would behave } \\
\text { sluggishly. } \\
\text { Low DO, -OR- } \\
\text { More pollutants } \\
\text { (chemicals) }\end{array}$ & $\begin{array}{l}\text { What is the name for } \\
\text { the "fan" that forms at } \\
\text { the base of a river? } \\
\text { Alluvial fan }\end{array}$ & $\begin{array}{l}\text { This measurement } \\
\text { determines how } \\
\text { organisms use } \\
\text { oxygen. } \\
\text { BOD, "Biological } \\
\text { Oxygen Demand" }\end{array}$ & $\begin{array}{l}\text { Name 2 "best } \\
\text { practice" } \\
\text { alternatives to } \\
\text { paving an area. } \\
\text { Gravel, Grass, } \\
\text { Surround with } \\
\text { vegetation... etc. }\end{array}$ & $\begin{array}{l}\text { What is the } \\
\text { name of } \\
\text { stratified water } \\
\text { layer? } \\
\text { Thermocline }\end{array}$ \\
\hline
\end{tabular}


DAY 11-12.

Application: real data from Dollar Bay

Materials: PowerPoint presentation, projector, worksheets with data

1. Review the following water quality concepts: Stratification, Density, Dissolved Oxygen, Consumption of DO (Listed DO module worksheet in the "biological" category), and Improvements for DO levels (bubbler, restoration from pollution, eliminate sources).

2. Graphical Analysis: The following Temperature and Dissolved Oxygen data from Dollar Bay was recorded on March 17, 2004. The \% Saturation of Dissolved Oxygen was calculated.
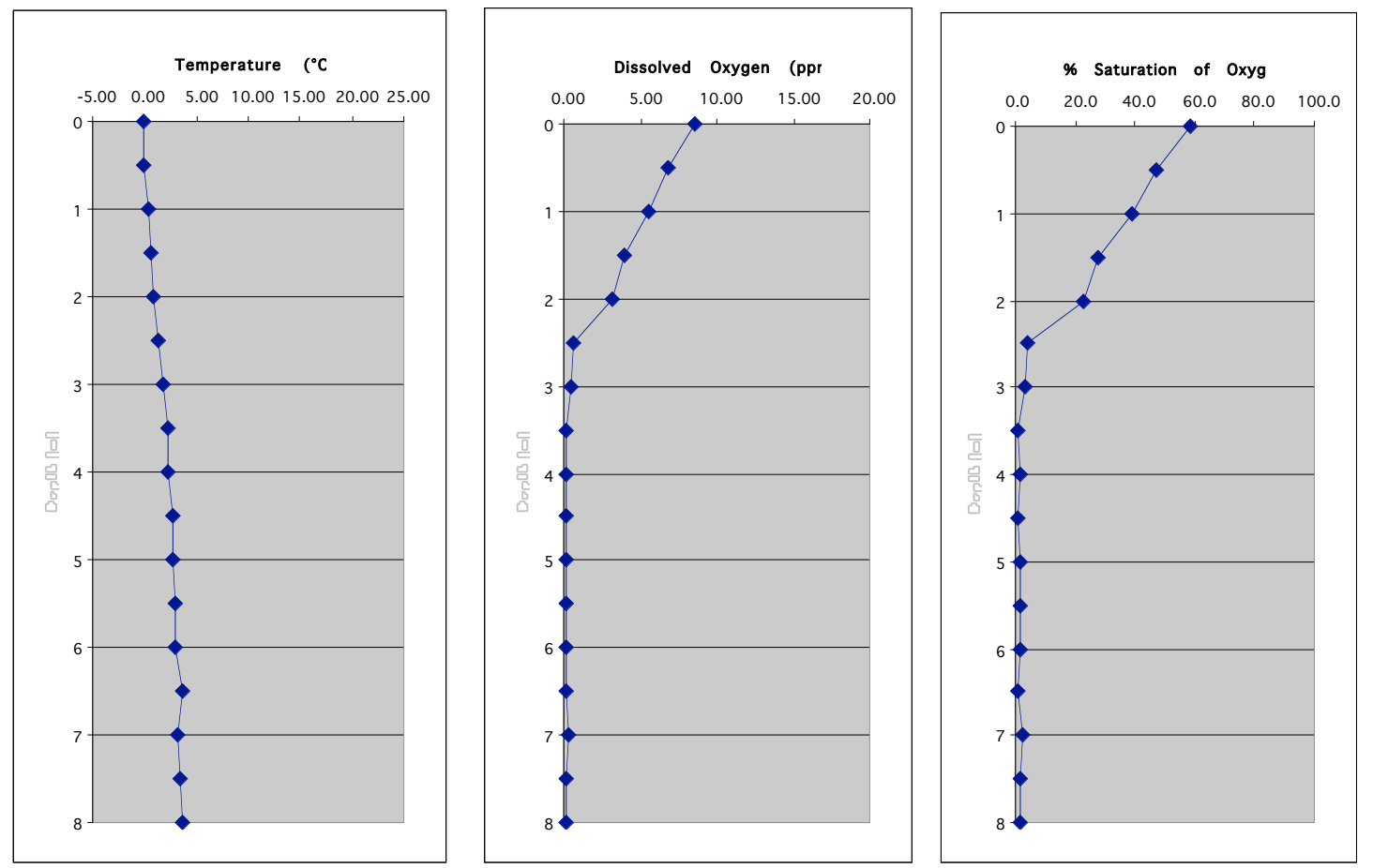

3. Create an illustration for water quality for one annual cycle.
A. Figure 2. Using the worksheet for one cycle of Temperature data, have students plot lines by connecting 'dots' numerically. Finalize the illustration by shading each 'numbered section' and color-coding warm sections red and cold sections blue.
B. Figure 3. Using the worksheet for one cycle of Dissolved Oxygen data, have students plot lines by connecting 'dots' numerically. Finalize the illustration by shading each 'numbered section' and color-coding low DO levels red and cold DO levels blue.

4. Conclusions: Relating biological and chemical (temperature \& DO) variables
A. Return to Focus Question "Why is water quality important?"
B. Look at the changes in water quality over time.
C. Consider changes in water quality with factors such as pollution and identify 'cause and effect" for the factors.


Figure 2. Student Worksheet to plot Temperature Data from Dollar Bay

\begin{tabular}{|c|c|c|c|c|c|c|c|c|c|c|c|c|c|c|c|c|c|c|}
\hline Depth & & & & & & & & Tel & mper & rature & e $\left({ }^{\circ} \mathrm{C}\right)$ & & & & & & & \\
\hline (m) & $\begin{array}{l}17- \\
\text { Mar }\end{array}$ & $\begin{array}{l}23- \\
\mathrm{Apr}\end{array}$ & $\begin{array}{c}7- \\
\text { May }\end{array}$ & $\begin{array}{l}19- \\
\text { May }\end{array}$ & 4-Jur & $\left\lfloor\begin{array}{l}18- \\
\text { Jun }\end{array}\right.$ & 2-Jul & \begin{tabular}{l|l}
$16-$ \\
$\mathrm{Jul}$
\end{tabular} & $\begin{array}{l}30- \\
\text { Jul }\end{array}$ & \begin{tabular}{c|c}
$13-$ \\
Aug
\end{tabular} & $\begin{array}{l}\text { 29- } \\
\text { Aug }\end{array}$ & \begin{tabular}{l|l}
$10-$ \\
Sep
\end{tabular} & \begin{tabular}{l|l}
$24-$ \\
Sep
\end{tabular} & 6-Oct & $\begin{array}{l}21- \\
\text { Oct }\end{array}$ & \begin{tabular}{|c}
$6-$ \\
Nov \\
\end{tabular} & $\begin{array}{l}24- \\
\text { Nov } \\
\end{array}$ & 2-Feb \\
\hline 0 & -0.17 & 8.51 & 10.62 & 15.60 & 18.50 & 17.90 & 20.24 & 22.12 & 23.38 & 820.40 & 18.55 & 20.41 & 18.40 & 13.059 & 9.04 & 6.68 & 2.65 & -0.21 \\
\hline 0.5 & 0.03 & 8.50 & 10.59 & 15.56 & 18.42 & 19.50 & 20.15 & 22.12 & 23.34 & 420.37 & 18.53 & 20.40 & 18.41 & 13.008 & 8.98 & 6.64 & 2.71 & -0.07 \\
\hline 1.0 & 0.28 & 8.49 & 10.54 & 15.00 & 16.33 & 19.46 & 19.74 & 21.88 & 22.72 & 219.57 & 18.51 & 20.30 & 18.40 & 12.928 & 8.80 & 6.63 & 2.85 & 0.06 \\
\hline 1.5 & 0.51 & 8.37 & 10.44 & 14.60 & 13.94 & 19.47 & 19.47 & 20.56 & 22.53 & 318.70 & 18.50 & 20.14 & 18.40 & 12.608 & 8.60 & 6.62 & 2.81 & 0.16 \\
\hline 2.0 & 0.78 & 8.21 & 10.17 & 12.50 & 12.73 & 19.34 & 19.24 & 19.70 & 22.06 & 618.48 & 318.33 & 19.01 & 18.40 & 12.168 & 8.42 & 6.62 & 2.80 & 0.44 \\
\hline 2.5 & 1.29 & 8.12 & 9.77 & 11.40 & 11.50 & 19.16 & 18.31 & 18.84 & 20.94 & 418.19 & 17.94 & 18.84 & 18.39 & 11.788 & 8.36 & 6.62 & 2.82 & 1.01 \\
\hline 3.0 & 1.71 & 7.96 & 9.28 & 10.80 & 10.75 & 16.60 & 17.32 & 17.57 & 19.60 & $\begin{array}{ll}0 & 18.06\end{array}$ & 17.72 & 18.70 & 18.24 & 411.708 & 8.30 & 6.61 & 2.85 & 1.66 \\
\hline 3.5 & 2.27 & 7.04 & 9.15 & 10.40 & 10.11 & 13.72 & 16.00 & 16.12 & 18.02 & 217.92 & 17.59 & 18.40 & 17.69 & 11.628 & 8.28 & 6.61 & 2.85 & 2.66 \\
\hline 4.0 & 2.34 & 6.61 & 9.14 & 9.93 & 9.71 & 12.22 & 14.30 & 14.99 & 15.90 & 017.35 & 17.24 & 17.33 & 17.43 & 311.548 & 8.25 & 6.61 & 2.82 & 2.55 \\
\hline 4.5 & 2.69 & 6.41 & 8.96 & 9.82 & 9.61 & 11.19 & 12.65 & 13.93 & 13.70 & $\begin{array}{ll}0 & 16.27\end{array}$ & 716.41 & 16.70 & 16.81 & 11.528 & 8.21 & 6.60 & 2.83 & 2.77 \\
\hline 5.0 & 2.79 & 6.14 & 8.36 & 9.28 & 9.48 & 10.77 & 11.18 & 12.16 & 12.27 & 714.15 & 15.45 & 15.88 & 13.69 & 11.508 & 8.10 & 6.60 & 2.86 & 2.93 \\
\hline 5.5 & 2.88 & 5.84 & 8.22 & 8.90 & 9.43 & 9.77 & 10.45 & 11.14 & 11.48 & 812.05 & 513.97 & 14.03 & 12.75 & 511.478 & 8.00 & 6.60 & 2.86 & 3.10 \\
\hline 6.0 & 2.91 & 5.50 & 8.22 & 8.76 & 9.31 & 9.48 & 9.87 & 10.53 & 10.95 & 511.48 & 12.16 & 13.43 & 12.43 & 11.438 & 8.00 & 6.57 & 2.85 & 3.28 \\
\hline 6.5 & 3.73 & 5.44 & 8.13 & 8.73 & 9.28 & 9.21 & 9.60 & 10.14 & 10.50 & 011.12 & 11.40 & 12.00 & 11.70 & 11.408 & 8.00 & 6.50 & 2.96 & 3.44 \\
\hline 7.0 & 3.28 & 5.42 & 8.01 & 8.71 & 9.23 & 9.22 & 9.47 & 10.00 & 10.12 & 210.60 & 10.93 & 311.97 & 11.70 & 11.427 & 7.98 & 6.51 & 2.96 & 3.61 \\
\hline 7.5 & 3.47 & 5.30 & 7.93 & 8.60 & 9.15 & 9.14 & 9.29 & 9.90 & 9.99 & 10.27 & 10.68 & 11.45 & 11.43 & 311.407 & 7.95 & 6.41 & 2.94 & 3.95 \\
\hline Bottom & 3.68 & & 7.45 & & 9.04 & 9.09 & 9.22 & 9.76 & 9.93 & 10.40 & 10.61 & 11.23 & 11.32 & 211.417 & 7.95 & 5.14 & 2.33 & 4.05 \\
\hline
\end{tabular}


Figure 3. Student Worksheet to plot Dissolved Oxygen Data from Dollar Bay

\begin{tabular}{|c|c|c|c|c|c|c|c|c|c|c|c|c|c|c|c|c|c|c|}
\hline Depth & & & & & & & Dis & ssol & ed & Dxyge & en (p & pm) & & & & & & \\
\hline (m) & $\begin{array}{l}17- \\
\text { Mar }\end{array}$ & $\begin{array}{l}23- \\
\mathrm{Apr}\end{array}$ & $\begin{array}{c}7- \\
\text { May }\end{array}$ & $\begin{array}{l}19- \\
\text { May }\end{array}$ & 4-Jun & $\mid \begin{array}{l}18- \\
\text { Jun }\end{array}$ & 2-Jul & $\mid \begin{array}{c}16- \\
\text { Jul }\end{array}$ & $\mid \begin{array}{l}30- \\
\mathrm{Jul}\end{array}$ & $\begin{array}{l}13- \\
\text { Aug } \\
\end{array}$ & $\begin{array}{l}29- \\
\text { Aug } \\
\end{array}$ & $\begin{array}{l}10- \\
\text { Sep }\end{array}$ & $\begin{array}{l}24- \\
\text { Sep }\end{array}$ & 6-Oct & $\mid \begin{array}{l}21- \\
\text { Oct }\end{array}$ & $\begin{array}{c}6- \\
\text { Nov } \\
\end{array}$ & $\begin{array}{l}24- \\
\text { Nov }\end{array}$ & $\begin{array}{c}2- \\
\text { Feb }\end{array}$ \\
\hline 0 & 8.64 & 10.21 & 9.67 & 8.90 & 8.54 & 8.16 & 8.04 & 7.31 & 6.42 & 6.63 & 9.10 & 10.21 & 8.82 & 9.72 & 9.73 & 8.53 & 12.54 & 6.35 \\
\hline 0.5 & 6.88 & 10.10 & 9.77 & 8.94 & 8.39 & 7.53 & 7.85 & 7.22 & 6.52 & 6.37 & 8.75 & 9.73 & 8.24 & 9.44 & 9.50 & 8.45 & 11.78 & 5.84 \\
\hline 1.0 & 5.62 & 10.04 & 9.67 & 9.00 & 8.63 & 7.38 & 7.74 & 7.06 & 6.50 & 6.33 & 8.70 & 9.74 & 8.03 & 9.41 & 9.57 & 8.37 & 11.66 & 5.52 \\
\hline 1.5 & 4.00 & 9.93 & 9.57 & 8.85 & 7.57 & 7.30 & 7.64 & 6.94 & 6.27 & 6.26 & 8.54 & 9.70 & 8.10 & 9.55 & 9.62 & 8.36 & 11.61 & 5.22 \\
\hline 2.0 & 3.25 & 9.87 & 9.54 & 8.60 & 7.60 & 7.16 & 7.35 & 6.96 & 5.52 & 6.39 & 8.18 & 9.49 & 8.15 & 9.43 & 9.69 & 8.35 & 11.52 & 4.92 \\
\hline 2.5 & 0.58 & 9.77 & 9.73 & 7.90 & 7.05 & 6.78 & 6.41 & 6.32 & 4.79 & 6.32 & 7.72 & 8.49 & 7.87 & 9.26 & 9.68 & 8.41 & 11.53 & 2.22 \\
\hline 3.0 & 0.41 & 9.56 & 9.40 & 7.77 & 6.94 & 4.58 & 4.66 & 3.80 & 5.50 & 6.06 & 7.20 & 8.50 & 7.03 & 9.26 & 9.66 & 8.38 & 11.46 & 3.55 \\
\hline 3.5 & 0.15 & 9.46 & 9.38 & 7.20 & 6.69 & 3.60 & 3.30 & 2.83 & 1.95 & 5.65 & 6.62 & 7.17 & 5.50 & 9.19 & 9.75 & 8.39 & 11.42 & 3.76 \\
\hline 4.0 & 0.23 & 9.41 & 9.30 & 6.80 & 6.53 & 3.06 & 1.10 & 1.50 & 0.70 & 4.42 & 5.16 & 1.62 & 5.45 & 9.15 & 9.75 & 8.47 & 11.44 & 2.78 \\
\hline 4.5 & 0.15 & 9.44 & 9.25 & 6.41 & 6.43 & 2.96 & 0.30 & 0.42 & 0.36 & 2.35 & 2.00 & 0.33 & 5.27 & 9.12 & 9.67 & 8.44 & 11.49 & 1.58 \\
\hline 5.0 & 0.20 & 9.44 & 8.75 & 6.03 & 5.96 & 2.72 & 0.23 & 0.20 & 0.27 & 0.78 & 0.32 & 0.20 & 4.60 & 9.00 & 9.63 & 8.44 & 11.38 & 0.76 \\
\hline 5.5 & 0.18 & 9.34 & 8.66 & 5.69 & 5.68 & 2.28 & 0.22 & 0.17 & 0.19 & 0.59 & 0.12 & 0.18 & 4.56 & 8.94 & 9.53 & 8.41 & 11.44 & 0.30 \\
\hline 6.0 & 0.18 & 9.28 & 8.60 & 5.74 & 5.05 & 1.91 & 0.17 & 0.15 & 0.17 & 0.44 & 0.18 & 0.18 & 4.57 & 8.96 & 9.44 & 8.55 & 11.38 & 0.25 \\
\hline 6.5 & 0.14 & 9.06 & 8.49 & 5.80 & 4.82 & 1.60 & 0.15 & 0.15 & 0.17 & 0.29 & 0.18 & 0.16 & 4.53 & 8.89 & 9.40 & 8.53 & 11.37 & 0.23 \\
\hline 7.0 & 0.29 & 8.80 & 8.33 & 5.71 & 4.43 & 1.22 & 0.16 & 0.14 & 0.16 & 0.25 & 0.19 & 0.15 & 4.40 & 8.64 & 9.32 & 8.55 & 11.40 & 0.23 \\
\hline 7.5 & 0.21 & 6.20 & 7.51 & 3.59 & 4.01 & 0.85 & 0.15 & 0.14 & 0.15 & 0.21 & 0.17 & 0.15 & 4.30 & 8.45 & 9.20 & 8.55 & 11.38 & 0.21 \\
\hline Bottom & 0.22 & & 3.66 & & 1.16 & 0.27 & 0.12 & 0.13 & 0.13 & 0.19 & 0.17 & 0.14 & 4.17 & 8.19 & 8.70 & 8.65 & 8.60 & 0.20 \\
\hline
\end{tabular}


Figure 4. Student Worksheet to plot \% Saturation of Dissolved Oxygen

\section{Data from Dollar Bay}

\begin{tabular}{|c|c|c|c|c|c|c|c|c|c|c|c|c|c|c|c|c|c|c|}
\hline Depth & & & & & & erce & nt Sa & tura & ion & $f$ Dis & solv & ed 0 & xyge & & & & & \\
\hline$(\mathrm{m})$ & $\begin{array}{c}17- \\
\text { Mar }\end{array}$ & $\begin{array}{l}23- \\
\mathrm{Apr}\end{array}$ & $\begin{array}{c}7- \\
\text { May }\end{array}$ & $\begin{array}{c}19- \\
\text { May }\end{array}$ & 4-Jun & \begin{tabular}{|l}
$18-$ \\
Jun
\end{tabular} & 2-Jul & $\begin{array}{l}16- \\
\text { Jul }\end{array}$ & $\begin{array}{l}30- \\
\text { Jul }\end{array}$ & $\begin{array}{r}13- \\
\text { Aug } \\
\end{array}$ & $\begin{array}{l}29- \\
\text { Aug } \\
\end{array}$ & \begin{tabular}{|l|}
$10-$ \\
Sep
\end{tabular} & $\begin{array}{l}24- \\
\text { Sep } \\
\end{array}$ & 6-Oct & $\begin{array}{l}21- \\
\text { Oct } \\
\end{array}$ & $\begin{array}{c}6- \\
\text { Nov } \\
\end{array}$ & $\begin{array}{l}24- \\
\text { Nov } \\
\end{array}$ & 2-Feb \\
\hline 0 & 58.8 & 87.3 & 86.9 & 89.4 & 91.1 & 86.0 & 88.8 & 83.8 & 75.4 & 73.5 & 97.2 & 113.2 & 93.9 & 92.4 & 84.3 & 69.7 & 92.3 & 43.2 \\
\hline 0.5 & 47.1 & 86.3 & 87.8 & 89.7 & 89.4 & 82.0 & 86.6 & 82.6 & 76.5 & 70.6 & 93.4 & 107.9 & 87.8 & 89.6 & 82.1 & 69.0 & 86.8 & 39.9 \\
\hline 1.0 & 38.7 & 85.8 & 86.8 & 89.3 & 88.0 & 80.3 & 84.7 & 80.6 & 75.4 & 69.0 & 92.9 & 107.8 & 85.5 & 89.1 & 82.4 & 68.3 & 86.3 & 37.8 \\
\hline 1.5 & 27.8 & 84.6 & 85.7 & 87.0 & 73.4 & 79.4 & 83.1 & 77.2 & 72.4 & 67.1 & 91.1 & 107.0 & 86.3 & 89.8 & 82.4 & 68.2 & 85.8 & 35.7 \\
\hline 2.0 & 22.7 & 83.8 & 84.9 & 80.7 & 71.7 & 77.7 & 79.6 & 76.1 & 63.2 & 68.2 & 87.0 & 102.3 & 86.8 & 87.8 & 82.7 & 68.1 & 85.1 & 34.1 \\
\hline 2.5 & 4.1 & 82.7 & 85.7 & 72.3 & 64.7 & 73.3 & 68.1 & 67.9 & 53.7 & 67.0 & 81.4 & 91.2 & 83.8 & 85.5 & 82.5 & 68.6 & 85.2 & 15.6 \\
\hline 3.0 & 2.9 & 80.6 & 81.9 & 70.1 & 62.6 & 47.0 & 48.5 & 39.8 & 60.0 & 64.1 & 75.6 & 91.1 & 74.6 & 85.3 & 82.2 & 68.4 & 84.8 & 25.4 \\
\hline 3.5 & 1.1 & 78.0 & 81.4 & 64.4 & 59.4 & 34.7 & 33.4 & 28.7 & 20.6 & 59.6 & 69.3 & 76.4 & 57.7 & 84.5 & 82.9 & 68.4 & 84.5 & 27.4 \\
\hline 4.0 & 1.7 & 76.8 & 80.7 & 60.1 & 57.5 & 28.5 & 10.7 & 14.9 & 7.1 & 46.1 & 52.7 & 16.9 & 56.9 & 84.0 & 82.8 & 69.1 & 84.6 & 20.4 \\
\hline 4.5 & 1.1 & 76.6 & 79.9 & 56.5 & 56.4 & 27.0 & 2.8 & 4.1 & 3.5 & 23.9 & 20.4 & 3.4 & 54.3 & 83.7 & 82.1 & 68.8 & 85.0 & 11.7 \\
\hline 5.0 & 1.5 & 76.1 & 74.5 & 52.5 & 52.2 & 24.5 & 2.1 & 1.9 & 2.5 & 7.6 & 1.2 & 2.0 & 44.3 & 82.6 & 81.5 & 68.8 & 84.2 & 5.6 \\
\hline 5.5 & 1.3 & 74.7 & 73.5 & 49.1 & 49.6 & 20.1 & 2.0 & 1.5 & 1.7 & 5.5 & 1.7 & 1.7 & 43.0 & 82.0 & 80.5 & 68.5 & 84.7 & 2.2 \\
\hline 6.0 & 1.3 & 73.6 & 73.0 & 49.4 & 44.0 & 16.7 & 1.5 & 1.3 & 1.5 & 4.0 & 1.7 & 1.7 & 42.8 & 82.1 & 79.7 & 69.6 & 84.2 & 1.9 \\
\hline 6.5 & 1.1 & 71.7 & 71.9 & 49.8 & 42.0 & 13.9 & 1.3 & 1.3 & 1.5 & 2.6 & 1.7 & 1.5 & 41.7 & 81.4 & 79.4 & 69.4 & 84.4 & 1.7 \\
\hline 7.0 & 2.2 & 69.7 & 70.4 & 49.1 & 38.5 & 10.6 & 1.4 & 1.2 & 1.4 & 2.2 & 1.5 & 1.4 & 40.5 & 79.1 & 78.7 & 69.4 & 84.6 & 1.7 \\
\hline 7.5 & 1.6 & 48.9 & 63.3 & 30.8 & 34.8 & 7.4 & 1.3 & 1.2 & 1.3 & 1.9 & 1.5 & 1.4 & 39.4 & 77.3 & 77.6 & 65.2 & 84.4 & 1.6 \\
\hline Bottom & 1.7 & & 30.5 & & 10.0 & 2.3 & 1.0 & 1.1 & 1.1 & 1.7 & 0.0 & 1.3 & 38.1 & 75.0 & 73.4 & 68.1 & 62.7 & 1.5 \\
\hline
\end{tabular}


(This page is deliberately blank) 
Appendix B - Tables of Results for Individual Classes 
(This page is deliberately blank) 
Table 11. Pretest \& Posttest Knowledge Performance of First Hour Class

\begin{tabular}{|c|c|c|c|c|c|c|c|c|c|}
\hline \multirow[b]{2}{*}{ Item \# } & \multirow[b]{2}{*}{$\mathrm{N}$} & \multicolumn{3}{|c|}{ Pretest } & \multicolumn{3}{|c|}{ Posttest } & \multirow[b]{2}{*}{ Change } & \multirow{2}{*}{$\begin{array}{c}\text { Effect } \\
\text { Size }\end{array}$} \\
\hline & & \#Correct & Class $\bar{X}$ & $\mathrm{SD}$ & \#Correct & Class $\bar{X}$ & $\mathrm{SD}$ & & \\
\hline 1 & 21 & 5 & $23.8 \%$ & 0.43 & 5 & $23.8 \%$ & 0.43 & $0.0 \%$ & 0.0 \\
\hline 2 & 21 & 18 & $85.7 \%$ & 0.35 & 16 & $76.2 \%$ & 0.43 & $-9.5 \%$ & -0.3 \\
\hline 3 & 21 & 5 & $23.8 \%$ & 0.43 & 8 & $38.1 \%$ & 0.49 & $14.3 \%$ & 0.3 \\
\hline 4 & 21 & 13 & $61.9 \%$ & 0.49 & 15 & $71.4 \%$ & 0.45 & $9.5 \%$ & 0.2 \\
\hline 5 & 21 & 7 & $33.3 \%$ & 0.47 & 13 & $61.9 \%$ & 0.49 & $28.6 \%$ & 0.6 \\
\hline 6 & 21 & 3 & $14.3 \%$ & 0.35 & 13 & $61.9 \%$ & 0.49 & $47.6 \%$ & 1.4 \\
\hline 7 & 21 & 15 & $71.4 \%$ & 0.45 & 13 & $61.9 \%$ & 0.49 & $-9.5 \%$ & -0.2 \\
\hline 8 & 21 & 19 & $90.5 \%$ & 0.29 & 21 & $100.0 \%$ & 0.00 & $9.5 \%$ & 0.3 \\
\hline 9 & 21 & 3 & $14.3 \%$ & 0.35 & 3 & $14.3 \%$ & 0.35 & $0.0 \%$ & 0.0 \\
\hline 10 & 21 & 11 & $52.4 \%$ & 0.50 & 8 & $38.1 \%$ & 0.49 & $-14.3 \%$ & -0.3 \\
\hline 11 & 21 & 7 & $33.3 \%$ & 0.47 & 17 & $81.0 \%$ & 0.39 & $47.6 \%$ & 1.0 \\
\hline 12 & 21 & 14 & $66.7 \%$ & 0.47 & 16 & $76.2 \%$ & 0.43 & $9.5 \%$ & 0.2 \\
\hline 13 & 21 & 16 & $76.2 \%$ & 0.43 & 19 & $90.5 \%$ & 0.29 & $14.3 \%$ & 0.3 \\
\hline 14 & 21 & 2 & $9.5 \%$ & 0.29 & 10 & $47.6 \%$ & 0.50 & $38.1 \%$ & 1.3 \\
\hline 15 & 21 & 2 & $9.5 \%$ & 0.29 & 5 & $23.8 \%$ & 0.43 & $14.3 \%$ & 0.5 \\
\hline 16 & 21 & 9 & $42.9 \%$ & 0.49 & 13 & $61.9 \%$ & 0.49 & $19.0 \%$ & 0.4 \\
\hline 17 & 21 & 4 & $19.0 \%$ & 0.39 & 17 & $81.0 \%$ & 0.39 & $61.9 \%$ & 1.6 \\
\hline 18 & 21 & 5 & $23.8 \%$ & 0.43 & 6 & $28.6 \%$ & 0.45 & $4.8 \%$ & 0.1 \\
\hline Avera & & 8.8 & $41.8 \%$ & 0.41 & 12.1 & $57.7 \%$ & 0.41 & $15.9 \%$ & 0.41 \\
\hline
\end{tabular}


Table 12. Pretest \& Posttest Knowledge Performance of Third Hour Class

\begin{tabular}{|c|c|c|c|c|c|c|c|c|c|}
\hline \multirow[b]{2}{*}{ Item \# } & \multirow[b]{2}{*}{$\mathrm{N}$} & \multicolumn{3}{|c|}{ Pretest } & \multicolumn{3}{|c|}{ Posttest } & \multirow[b]{2}{*}{ Change } & \multirow{2}{*}{$\begin{array}{c}\text { Effect } \\
\text { Size }\end{array}$} \\
\hline & & \#Correct & Class $\bar{X}$ & $\mathrm{SD}$ & \#Correct & Class $\bar{X}$ & $\mathrm{SD}$ & & \\
\hline 1 & 27 & 8 & $29.6 \%$ & 0.46 & 10 & $37.0 \%$ & 0.48 & $7.4 \%$ & 0.2 \\
\hline 2 & 27 & 18 & $66.7 \%$ & 0.47 & 15 & $56.6 \%$ & 0.50 & $-11.1 \%$ & -0.2 \\
\hline 3 & 27 & 7 & $25.9 \%$ & 0.44 & 7 & $25.9 \%$ & 0.44 & $0.0 \%$ & 0.0 \\
\hline 4 & 27 & 10 & $37.0 \%$ & 0.48 & 16 & $59.3 \%$ & 0.49 & $22.2 \%$ & 0.5 \\
\hline 5 & 27 & 16 & $59.3 \%$ & 0.49 & 18 & $66.7 \%$ & 0.47 & $7.4 \%$ & 0.2 \\
\hline 6 & 27 & 8 & $29.6 \%$ & 0.46 & 21 & $77.8 \%$ & 0.42 & $48.1 \%$ & 1.1 \\
\hline 7 & 27 & 1 & $3.7 \%$ & 0.19 & 16 & $59.3 \%$ & 0.49 & $55.6 \%$ & 2.9 \\
\hline 8 & 27 & 21 & $77.8 \%$ & 0.42 & 20 & $74.1 \%$ & 0.44 & $-3.7 \%$ & -0.1 \\
\hline 9 & 27 & 11 & $40.7 \%$ & 0.49 & 12 & $44.4 \%$ & 0.50 & $3.7 \%$ & 0.1 \\
\hline 10 & 27 & 11 & $40.7 \%$ & 0.49 & 18 & $66.7 \%$ & 0.47 & $25.9 \%$ & 0.5 \\
\hline 11 & 27 & 8 & $29.6 \%$ & 0.46 & 21 & $77.8 \%$ & 0.42 & $48.1 \%$ & 1.1 \\
\hline 12 & 27 & 22 & $81.5 \%$ & 0.39 & 20 & $74.1 \%$ & 0.44 & $-7.4 \%$ & -0.2 \\
\hline 13 & 27 & 14 & $51.9 \%$ & 0.50 & 18 & $66.7 \%$ & 0.47 & $14.8 \%$ & 0.3 \\
\hline 14 & 27 & 4 & $14.8 \%$ & 0.36 & 17 & $63.0 \%$ & 0.48 & $48.1 \%$ & 1.4 \\
\hline 15 & 27 & 2 & $7.4 \%$ & 0.26 & 6 & $22.2 \%$ & 0.42 & $14.8 \%$ & 0.6 \\
\hline 16 & 27 & 7 & $25.9 \%$ & 0.44 & 16 & $59.3 \%$ & 0.49 & $33.3 \%$ & 0.8 \\
\hline 17 & 27 & 11 & $40.7 \%$ & 0.49 & 19 & $70.4 \%$ & 0.46 & $29.6 \%$ & 0.6 \\
\hline 18 & 27 & 14 & $51.9 \%$ & 0.50 & 21 & $77.8 \%$ & 0.42 & $25.9 \%$ & 0.5 \\
\hline Average & & 10.7 & $39.7 \%$ & 0.43 & 16.2 & $59.9 \%$ & 0.46 & $20.16 \%$ & 0.56 \\
\hline
\end{tabular}


Table 13. Pretest \& Posttest Knowledge Performance of Fourth Hour Class

\begin{tabular}{|c|c|c|c|c|c|c|c|c|c|}
\hline \multirow[b]{2}{*}{ Item \# } & \multirow[b]{2}{*}{$\mathrm{N}$} & \multicolumn{3}{|c|}{ Pretest } & \multicolumn{3}{|c|}{ Posttest } & \multirow[b]{2}{*}{ Change } & \multirow{2}{*}{$\begin{array}{c}\text { Effect } \\
\text { Size }\end{array}$} \\
\hline & & \#Correct & Class $\bar{X}$ & $\mathrm{SD}$ & \#Correct & Class $\bar{X}$ & SD & & \\
\hline 1 & 26 & 2 & $7.7 \%$ & 0.27 & 9 & $34.6 \%$ & 0.48 & $26.9 \%$ & 1.0 \\
\hline 2 & 26 & 22 & $84.6 \%$ & 0.36 & 20 & $76.9 \%$ & 0.42 & $-7.7 \%$ & -0.2 \\
\hline 3 & 26 & 2 & $7.7 \%$ & 0.27 & 8 & $30.8 \%$ & 0.46 & $23.1 \%$ & 0.9 \\
\hline 4 & 26 & 13 & $50.0 \%$ & 0.50 & 19 & $73.1 \%$ & 0.44 & $23.1 \%$ & 0.5 \\
\hline 5 & 26 & 15 & $57.7 \%$ & 0.49 & 16 & $61.5 \%$ & 0.49 & $3.8 \%$ & 0.1 \\
\hline 6 & 26 & 6 & $23.1 \%$ & 0.42 & 17 & $65.4 \%$ & 0.48 & $42.3 \%$ & 1.0 \\
\hline 7 & 26 & 3 & $11.5 \%$ & 0.32 & 17 & $65.4 \%$ & 0.48 & $53.8 \%$ & 1.7 \\
\hline 8 & 26 & 18 & $69.2 \%$ & 0.46 & 21 & $80.8 \%$ & 0.39 & $11.5 \%$ & 0.3 \\
\hline 9 & 26 & 7 & $26.9 \%$ & 0.44 & 7 & $26.9 \%$ & 0.44 & $0.0 \%$ & 0.0 \\
\hline 10 & 26 & 11 & $42.3 \%$ & 0.49 & 20 & $76.9 \%$ & 0.42 & $34.6 \%$ & 0.7 \\
\hline 11 & 26 & 9 & $34.6 \%$ & 0.48 & 20 & $76.9 \%$ & 0.42 & $42.3 \%$ & 0.9 \\
\hline 12 & 26 & 22 & $84.6 \%$ & 0.36 & 21 & $80.8 \%$ & 0.39 & $-3.8 \%$ & -0.1 \\
\hline 13 & 26 & 10 & $38.5 \%$ & 0.49 & 22 & $84.6 \%$ & 0.36 & $46.2 \%$ & 0.9 \\
\hline 14 & 26 & 6 & $23.1 \%$ & 0.42 & 15 & $57.7 \%$ & 0.49 & $34.6 \%$ & 0.8 \\
\hline 15 & 26 & 7 & $26.9 \%$ & 0.44 & 6 & $23.1 \%$ & 0.42 & $-3.8 \%$ & -0.1 \\
\hline 16 & 26 & 5 & $19.2 \%$ & 0.39 & 9 & $34.6 \%$ & 0.48 & $15.4 \%$ & 0.4 \\
\hline 17 & 26 & 12 & $46.2 \%$ & 0.50 & 19 & $73.1 \%$ & 0.44 & $26.9 \%$ & 0.5 \\
\hline 18 & 26 & 14 & $53.8 \%$ & 0.50 & 18 & $69.2 \%$ & 0.46 & $15.4 \%$ & 0.3 \\
\hline Averag & & 10.2 & $39.3 \%$ & 0.42 & 15.8 & $60.7 \%$ & 0.44 & $21.4 \%$ & 0.53 \\
\hline
\end{tabular}


Table 14. Pretest \& Posttest Knowledge Performance of Fifth Hour Class

\begin{tabular}{|c|c|c|c|c|c|c|c|c|c|}
\hline \multirow[b]{2}{*}{ Item \# } & \multirow[b]{2}{*}{$\mathrm{N}$} & \multicolumn{3}{|c|}{ Pretest } & \multicolumn{3}{|c|}{ Posttest } & \multirow[b]{2}{*}{ Change } & \multirow{2}{*}{$\begin{array}{c}\text { Effect } \\
\text { Size }\end{array}$} \\
\hline & & \#Correct & Class $\bar{X}$ & $\mathrm{SD}$ & \#Correct & Class $\bar{X}$ & $\mathrm{SD}$ & & \\
\hline 1 & 27 & 1 & $3.7 \%$ & 0.19 & 0 & $0.0 \%$ & 0.0 & $-3.7 \%$ & -0.2 \\
\hline 2 & 27 & 21 & $77.8 \%$ & 0.42 & 22 & $81.5 \%$ & 0.39 & $3.7 \%$ & 0.1 \\
\hline 3 & 27 & 3 & $11.1 \%$ & 0.31 & 5 & $18.5 \%$ & 0.39 & $7.4 \%$ & 0.2 \\
\hline 4 & 27 & 10 & $37.0 \%$ & 0.48 & 13 & $48.1 \%$ & 0.50 & $11.1 \%$ & 0.2 \\
\hline 5 & 27 & 16 & $59.3 \%$ & 0.49 & 17 & $63.0 \%$ & 0.48 & $3.7 \%$ & 0.1 \\
\hline 6 & 27 & 7 & $25.9 \%$ & 0.44 & 18 & $66.7 \%$ & 0.47 & $40.7 \%$ & 0.9 \\
\hline 7 & 27 & 2 & $7.4 \%$ & 0.26 & 16 & $59.3 \%$ & 0.49 & $51.9 \%$ & 2.0 \\
\hline 8 & 27 & 21 & $77.8 \%$ & 0.42 & 21 & $77.8 \%$ & 0.42 & $0.0 \%$ & 0.0 \\
\hline 9 & 27 & 7 & $25.9 \%$ & 0.44 & 9 & $33.3 \%$ & 0.47 & $7.4 \%$ & 0.2 \\
\hline 10 & 27 & 9 & $33.3 \%$ & 0.47 & 19 & $70.4 \%$ & 0.46 & $37.0 \%$ & 0.8 \\
\hline 11 & 27 & 8 & $29.6 \%$ & 0.46 & 22 & $81.5 \%$ & 0.39 & $51.9 \%$ & 1.1 \\
\hline 12 & 27 & 24 & $89.9 \%$ & 0.31 & 24 & $88.9 \%$ & 0.31 & $0.0 \%$ & 0.0 \\
\hline 13 & 27 & 18 & $66.7 \%$ & 0.47 & 20 & $74.1 \%$ & 0.44 & $7.4 \%$ & 0.2 \\
\hline 14 & 27 & 4 & $14.8 \%$ & 0.36 & 16 & $59.3 \%$ & 0.49 & $44.4 \%$ & 1.3 \\
\hline 15 & 27 & 0 & $0.0 \%$ & 0.0 & 3 & $11.1 \%$ & 0.31 & $11.1 \%$ & 0.3 \\
\hline 16 & 27 & 8 & $29.6 \%$ & 0.46 & 12 & $44.4 \%$ & 0.50 & $14.8 \%$ & 0.3 \\
\hline 17 & 27 & 6 & $22.2 \%$ & 0.42 & 17 & $63.0 \%$ & 0.48 & $40.7 \%$ & 1.0 \\
\hline 18 & 27 & 0 & $0.0 \%$ & 0.0 & 16 & $59.3 \%$ & 0.49 & $59.3 \%$ & 1.7 \\
\hline Averag & & 9.2 & $34.0 \%$ & 0.35 & 15.3 & $55.6 \%$ & 0.42 & $21.6 \%$ & 0.56 \\
\hline
\end{tabular}


Table 15. Pretest \& Posttest Knowledge Performance of S.E. Hour Class

\begin{tabular}{|c|c|c|c|c|c|c|c|c|c|}
\hline \multirow[b]{2}{*}{ Item \# } & \multirow[b]{2}{*}{$\mathrm{N}$} & \multicolumn{3}{|c|}{ Pretest } & \multicolumn{3}{|c|}{ Posttest } & \multirow[b]{2}{*}{ Change } & \multirow{2}{*}{$\begin{array}{c}\text { Effect } \\
\text { Size }\end{array}$} \\
\hline & & \#Correct & Class $\bar{X}$ & $\mathrm{SD}$ & \#Correct & Class $\bar{X}$ & SD & & \\
\hline 1 & 16 & 1 & $6.3 \%$ & 0.24 & 6 & $37.5 \%$ & 0.48 & $31.3 \%$ & 1.3 \\
\hline 2 & 16 & 11 & $68.8 \%$ & 0.46 & 10 & $62.5 \%$ & 0.48 & $-6.3 \%$ & -0.1 \\
\hline 3 & 16 & 5 & $31.3 \%$ & 0.46 & 8 & $50.0 \%$ & 0.50 & $18.8 \%$ & 0.4 \\
\hline 4 & 16 & 3 & $18.8 \%$ & 0.39 & 12 & $75.0 \%$ & 0.43 & $56.3 \%$ & 1.4 \\
\hline 5 & 16 & 7 & $43.8 \%$ & 0.50 & 10 & $62.5 \%$ & 0.48 & $18.8 \%$ & 0.4 \\
\hline 6 & 16 & 9 & $56.3 \%$ & 0.50 & 11 & $68.8 \%$ & 0.46 & $12.5 \%$ & 0.3 \\
\hline 7 & 16 & 9 & $56.3 \%$ & 0.50 & 11 & $68.8 \%$ & 0.46 & $12.5 \%$ & 0.3 \\
\hline 8 & 16 & 11 & $68.8 \%$ & 0.46 & 2 & $12.5 \%$ & 0.33 & $-56.3 \%$ & -1.2 \\
\hline 9 & 16 & 5 & $31.3 \%$ & 0.46 & 6 & $37.5 \%$ & 0.48 & $6.3 \%$ & 0.1 \\
\hline 10 & 16 & 9 & $56.3 \%$ & 0.50 & 7 & $43.8 \%$ & 0.50 & $-12.5 \%$ & -0.3 \\
\hline 11 & 16 & 10 & $62.5 \%$ & 0.48 & 10 & $62.5 \%$ & 0.48 & $0.0 \%$ & 0.0 \\
\hline 12 & 16 & 8 & $50.0 \%$ & 0.50 & 13 & $81.3 \%$ & 0.39 & $31.3 \%$ & 0.6 \\
\hline 13 & 16 & 11 & $68.8 \%$ & 0.46 & 10 & $62.5 \%$ & 0.48 & $-6.3 \%$ & -0.1 \\
\hline 14 & 16 & 4 & $25.0 \%$ & 0.43 & 9 & $56.3 \%$ & 0.50 & $31.3 \%$ & 0.7 \\
\hline 15 & 16 & 11 & $68.8 \%$ & 0.46 & 8 & $50.0 \%$ & 0.50 & $-18.8 \%$ & -0.4 \\
\hline 16 & 16 & 7 & $43.8 \%$ & 0.50 & 13 & $81.3 \%$ & 0.39 & $37.5 \%$ & 0.8 \\
\hline 17 & 16 & 4 & $25.0 \%$ & 0.43 & 7 & $43.8 \%$ & 0.50 & $18.8 \%$ & 0.4 \\
\hline 18 & 16 & 7 & $43.8 \%$ & 0.50 & 8.0 & $50.0 \%$ & 0.50 & $6.3 \%$ & 0.1 \\
\hline Averag & & 7.2 & $45.8 \%$ & 0.46 & 8.9 & $55.9 \%$ & 0.46 & $10.1 \%$ & 0.26 \\
\hline
\end{tabular}


Table 16. Average Test Item Effect Size for all Five Classes

\begin{tabular}{|c|c|c|c|c|c|c|}
\hline \multirow[b]{2}{*}{ Item \# } & \multicolumn{5}{|c|}{ Average Effect Size by Class Period } & \multirow[b]{2}{*}{ Average } \\
\hline & 1 & 3 & 4 & 5 & S.E. & \\
\hline 1 & 0.0 & 0.2 & 1.0 & -0.2 & 1.3 & 0.5 \\
\hline 2 & -0.3 & -0.2 & -0.2 & 0.1 & -0.1 & -0.2 \\
\hline 3 & 0.3 & 0.0 & 0.9 & 0.2 & 0.4 & 0.4 \\
\hline 4 & 0.2 & 0.5 & 0.5 & 0.2 & 1.4 & 0.6 \\
\hline 5 & 0.6 & 0.2 & 0.1 & 0.1 & 0.4 & 0.3 \\
\hline 6 & 1.4 & 1.1 & 1.0 & 0.9 & 0.3 & 0.9 \\
\hline 7 & -0.2 & 2.9 & 1.7 & 2.0 & 0.3 & 1.3 \\
\hline 8 & 0.3 & -0.1 & 0.3 & 0.0 & -1.2 & -0.1 \\
\hline 9 & 0.0 & 0.1 & 0.0 & 0.2 & 0.1 & 0.1 \\
\hline 10 & -0.3 & 0.5 & 0.7 & 0.8 & -0.3 & 0.3 \\
\hline 11 & 1.0 & 1.1 & 0.9 & 1.1 & 0.0 & 0.8 \\
\hline 12 & 0.2 & -0.2 & -0.1 & 0.0 & 0.6 & 0.1 \\
\hline 13 & 0.3 & 0.3 & 0.9 & 0.2 & -0.1 & 0.3 \\
\hline 14 & 1.3 & 1.4 & 0.8 & 1.3 & 0.7 & 1.1 \\
\hline 15 & 0.5 & 0.6 & -0.1 & 0.3 & -0.4 & 0.2 \\
\hline 16 & 0.4 & 0.8 & 0.4 & 0.3 & 0.8 & 0.5 \\
\hline 17 & 1.6 & 0.6 & 0.5 & 1.0 & 0.4 & 0.8 \\
\hline 18 & 0.1 & 0.5 & 0.3 & 1.7 & 0.1 & 0.6 \\
\hline
\end{tabular}


Appendix C - Water Quality Research for Dollar Bay, Michigan 
(This page is deliberately blank) 


\section{Clinical Experience in Water Quality Research}

Dollar Bay, located in Houghton County, Michigan, has appeared 'less healthy' than other bodies of water in the Keweenaw Peninsula. My investigation into the water quality of Dollar Bay due to water temperature and dissolved oxygen concentration occurred over one annual cycle. Data collection began in March 2004 and continued through March 2005.

My investigation determined dissolved oxygen concentrations in water at various depths and temperature. The investigation included data collection of temperature and dissolved oxygen concentration during one annual cycle. Data indicated changes in temperature and dissolved oxygen concentration, which then determined water quality of Dollar Bay. The test area was located in Houghton County, Michigan.

\section{Procedures}

Since Dollar Bay is funnel shaped, the actual testing took place in the center of the bay, accessed by boat or by foot as weather permitted. Data was collected every two weeks except in the winter months, which was every four weeks. Data was attained using the Hydrolab Quanta Water Quality Monitoring System, which consists of a transmitter and a display unit. Measurements from the probe included depth, temperature, and dissolved oxygen concentrations. For more accurate results, the probe was calibrated periodically according to the manufacturer's specifications. (The main activities for calibration included checking the measurements of dissolved oxygen with a known value and changing the membrane on the dissolved oxygen sensor.) 
Measurements were taken every 0.5 -meter in depth until reaching the deepest part of Dollar Bay, which was approximately 8 meters in depth. At each increment of measurement, the temperature along with the dissolved oxygen concentration of the water was recorded in a surveyor's notebook. Once the dissolved oxygen was measured, the percentage of oxygen saturation was calculated. This was a more useful measurement because the oxygen concentrations become standardized based on how much oxygen the water could hold at that particular temperature.

\section{Data}

Data was included as Student Worksheets for Temperature (Figure 2), Dissolved Oxygen (Figure 3) and \% Saturation of Dissolved Oxygen (Figure 4). Data was then used to map the stratification that occurred over one annual cycle. The profile of one annual cycle was created for Temperature (Figure 5), Dissolved Oxygen (Figure 6), and \% Saturation of Dissolved Oxygen (Figure 7).

\section{Interpretation}

Distinctly observable changes occurred in Dollar Bay over the course of this investigation. Each collection follows the following trends:

1) Water at $4^{\circ} \mathrm{C}$ is most dense and carries oxygen dissolved in the water to the bottom of the water body.

2) When surface water was warmer than deeper water it held more dissolved oxygen.

3) Oxygen from the atmosphere moved to the surface water because of wind and currents in the water. 
4) Surface water had higher \% saturation of DO due to more available oxygen that replenished the supply of dissolved oxygen in the water as mixing occurs.

5) Anoxic conditions resulted during summer months, which would also occur in polluted bodies of water.

Table 17. Stratification of Dollar Bay by Season During One Annual Cycle.

\begin{tabular}{ccc}
\hline Season & Month & Mixed or Stratified \\
\hline Spring & March & Mixed \\
Summer & July & Stratified \\
Fall & October & Mixed \\
Winter & December-January & Stratified \\
\hline
\end{tabular}

\section{Conclusion}

As the difference (in temperature) between the top layer of water and the bottom becomes greater, a steeper curve was observed on the graphs until it became a 'step'. The point where this 'step' occurred was where the layers stratified. Stratification is the separation of water into layers; mixing occurs within the layers but not throughout the entire body of water. Once the stratification occurs, the layers remain separated until the difference of temperature lessens between the top and bottom layers of water (Dodson, 2005). When the difference became minimal (or essentially zero) the water mixed, which was illustrated as a straight vertical line on the graphs. 
Stratification, or lack of mixing, prevented dissolved particles in the water from moving between layers. The separation of these layers, called the thermocline, was viewed as a straight horizontal line on the graphs. Stratification resulted in no dissolved oxygen replacement at the bottom of the water body. Eventually this may result in hazardously low oxygen levels, below $4 \mathrm{mg} / \mathrm{L}$, or even anoxic conditions (an absence of oxygen) in the lower layer (Dodson, 2005). Consequently, the lack of oxygen affects the overall 'health' of the area since oxygen is necessary for the survival of most living organisms. As water stratified, oxygen was unable to reach the bottom layer of Dollar Bay. During the summer months, (July - August). Hence, anoxic conditions resulted on the bottom half of Dollar Bay (deeper than 4 meters). At this point the water was stratified, meaning oxygen at the surface cannot reach the bottom to replenish what has been consumed. This data indicated potential trouble for the water body as a habitat because there was not sufficient oxygen to support living organisms during this period of the year. Though it is not believed that Dollar Bay is polluted, similar trends have been observed in polluted bodies of water, such as the Mississippi River and the Gulf of Mexico because of the absence of oxygen that resulted from stratification. 
Figure 5. Temperature in Dollar Bay for One Annual Cycle

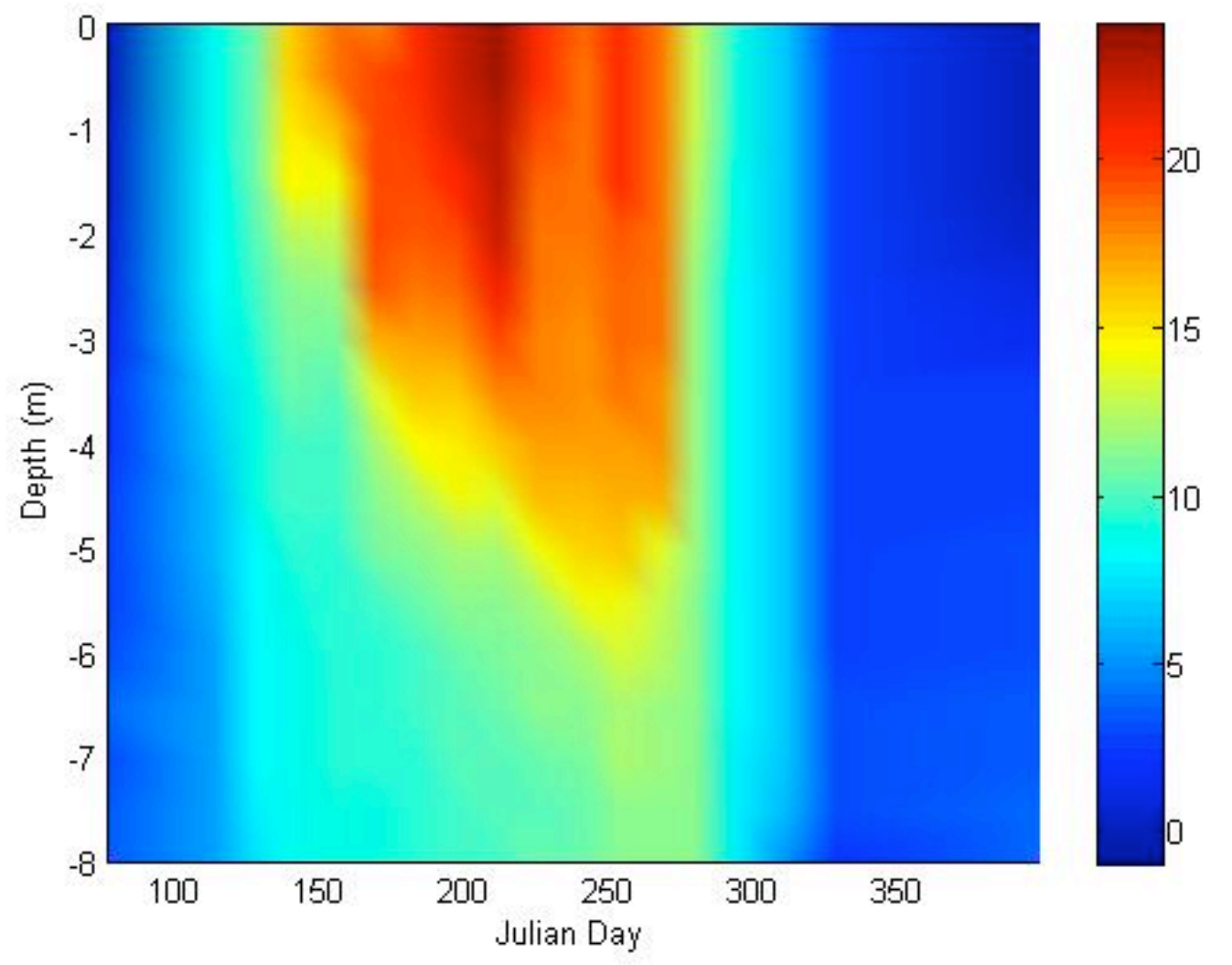

Illustration was produced by Edward M. Verhamme. 
Figure 6. Dissolved Oxygen in Dollar Bay for One Annual Cycle

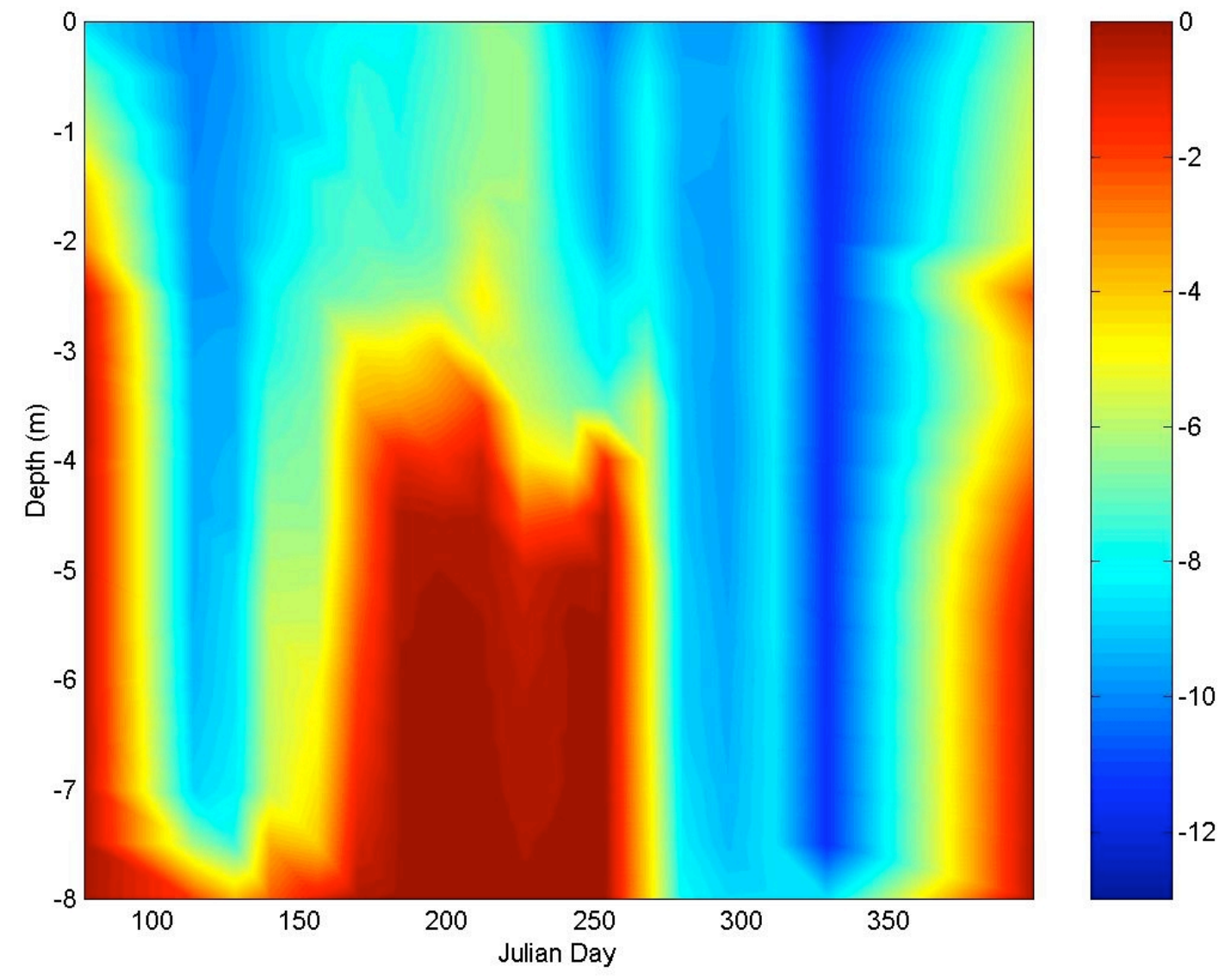

Illustration was produced by Edward M. Verhamme. 
Figure 7. Percent Saturation of Dissolved Oxygen in Dollar Bay for One

\section{Annual Cycle}

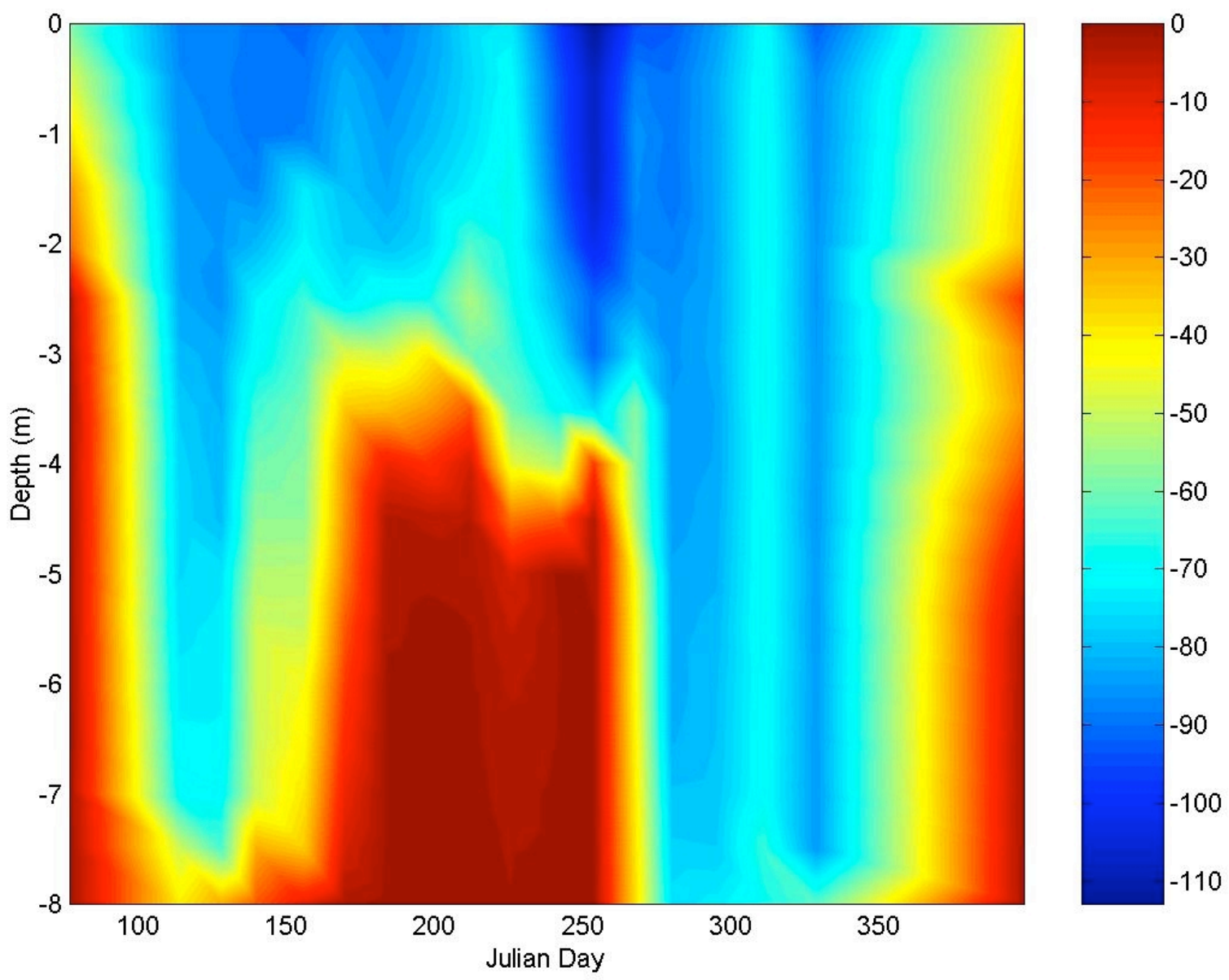

Illustration was produced by Edward M. Verhamme. 